\title{
INFLUENCE OF COLD
}

\section{ON HOST - PARASITE INTERACTIONS}

PART I

ord pyoposium

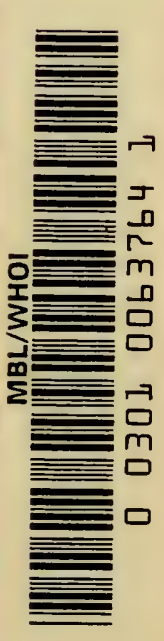

Editor

ELEANOR G. VIERECK

ARCTIC AEROMEDICAL LABORATORY

FORT WAINWRIGHT

A LASKA

\section{QP \\ 82 \\ A 75}

1963 

PROCEEDINGS

SYMPOSIA ON ARCTIC BIOLOGY AND MEDICINE

III. INFLUENCE OF COLD ON HOST-PARASITE INTERACTIONS

Symposium held August 28, 29, 30, 1962 at the

Arctic Aeromedical Laboratory

Fort Wainwright, Alaska

Symposium Organizer and Chairman

L. Joe Berry

Department of Biology, Bryn Mawr College

Editor

Eleanor G. Viereck

Research Physiologist, Arctic Aeromedical Laboratory

Symposium held under the auspices of the Geophysical Institute University of Alaska College, Alaska 


\section{Part I.}

1. Introduction to the Symposium, Influence of

Cold on Host-Parasite Interactions, L. Joe Berry . . . . . 1

2. Difficulties in Epidemiological Studies of the Relationship of Cold to Human Infections, Robert I. McClaughry .............. 11

3. Aspects of Arctic Epidemiology, Frank L.Babbott, Jr. . . 25

4. The Ecology of Enteroviruses in Alaska, Karl R. Reinhard ................ 4 47

5. Opening Remarks on Problems of Immunization in Stressed Animals, Dan H.Campbell ........ 81

6. Environmental Extremes and Endocrine Relationships in Antibody Formation, Ignatius L. Trapani . . . . . 89

7. Qualitative and Quantitative Aspects of the Immune Response under Conditions of Cold Exposure, William T. Northey .......... 109

8. Influence of Hypothermia on the Action of Bacterial Toxins, G. Tunevall and T. Lindner .... 135

Part II.

9. Effect of Low Ambient Temperatures on Specific and Nonspecific Resistance, Fred Miya, Stanley Marcus, and LeGrande J. Phelps . . . . . . . 155

10. Virulence as a Factor in Host Response to Bacterial Infection at Low Environmental Temperature, Joseph J. Previte and L. Joe Berry . . . 215 
11. Endogeneous and Experimental Peritonitis and Bacteraemia in Hypothermic Mice, G. Tunevall

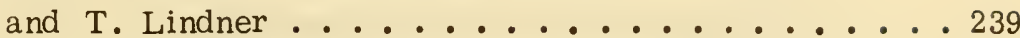

12. The Role of Low Environmental Temperatures

in Predisposing Mice to Seciondary Bacterial

Infection, Gennaro J. Miraglia and L. Joe Berry . . . 271

Part III.

13. Cold and Colds, Sir Christopher Andrewes ....... 301

14. Effect of Environmental Temperature on

Viral Infection, Duard L. Walker, M. D. . . . . . . 319

15. The Influence of Cold on Virus Infectivity,

Dr. T. G. Metcalf ............. . 343

16. Suppressive Effect of Low Environmental

Temperature on Viral Infection in Bats,

S. Edward Sulkin and Rae Allen ......... 369

17. Microbiological Aspects of Hibernation in

Ground Squirrels, J. Schmidt .......... 399

18. Cold Therapy in Bacteremic Shock, Emil Blair .....4 419

19. Summary of the Symposium, Walter J. Nungester . . . 447 


\section{DISCUSSANTS}

HORACE F. DRURY, Arctic Aeromedical Laboratory, Fort Wainwright, Alaska.

BOB HUNTLEY, Arctic Health Research Center, Anchorage, Alaska.

R. B. MTTCHELL, School of Aerospace Medicine, Brooks Air Force Base, Texas.

JOHN A. MONCREIF, Brooke Army Medical Center, Fort Sam Houston, Texas.

CHARLES T. MARROW, Fairbanks Medical and Surgical Clinic, Fairbanks, Alaska.

This publication has been released to the Office of Technical Services, U. S. Department of Commerce, Washington, 25, D. C. , for sale to the general public. 
INTRODUCTION TO THE SYMPOSIUM

INFLUENCE OF COLD ON HOST-PARASITE INTERACTIONS

L. Joe Berry

Department of Biology

Bryn Mawr College

Bryn Mawr, Pennsylvania

The purpose of the Symposium is familiar to all of you, but permit me the privilege of stating it in my own way. It is our task in the two and one-half days ahead tolook critically at an area that is part science, part superstition, and part unknown, with the view of determining how much time, effort, and money should be spent in its study. We must ask now and throughout the proceedings whether cold is an important factor in modifying or altering host-parasite interaction. We have been brought here by a branch of the Armed Forces of the United States because the medical authorities of that branch charged with the responsibilities of safe-guarding the health of military and civilian personnel, who are, for the sake of the security of our country, forced to live in hostile environments, need to have an answer. They are looking to us for help, and if it is within our wisdom to provide, I know we will. There is before us, therefore, a very real and practical problem which is our primary concern; but there is also the challenge of pure science. Medical and biological science from its earliest history has been preoccupied and inquisitive about the role the environment plays in the behavior and response of living organisms. I do not know to what extent the phases of the moon exert an influence at the time of planting or cultivating, or harvesting the yield and value of crops, but I have heard in my youth from many firm and dogmatic assertions by practicing farmers that they do. I also recall with some nostalgia my mother, my great aunts, and indeed, our faithful country doctor warning against wet feet, cold on the back of the neck, night air. cooling off too fast from a good sweat and the dire consequences (all of an infectious nature) that would ctherwise result. I remember with affection my mother's wish to protect me from the hostile 
rigors of a winter in the far north of Texas. Each October I went into long white underwear only to emerge in late March or early April when the air warmed to a comparatively safe $80^{\circ} \mathrm{F}$ to $90^{\circ} \mathrm{F}$. Many of these notions are firmly implanted in the minds of millions of people more from reiteration than by demonstration, to borrow a phrase from a friend (Schneider, 1946). But as is often the case, where conviction is firm, there is often more than a superstitious quicksand to give it support. We can now begin by examining some of the bases for this support, and, I hope, finding what there is of merit, what there is that is formless and amorphous, and where, if anywhere, new work is needed to give form to our knowledge.

In undertaking the responsibility of organizing this Symposium, it seemed to me that attention should first be directed to an analysis of past experience of Armed Forces in an arctic environment. During World War II and certainly in Korea, large bodies of men were forcec to live and fight at cruelly low temperatures. This was particularly true on the Russian front (for which no direct knowledge is readily accessible), but knowledge is available to an adequate degree around the Chosin reservoir in Korea. Casualties from frostbite were acknowledged, but the extent to which trained and seasoned troops were made more susceptible to microbic disease may never be known. It is to obtain as much information as possible on these points that Dr. McClaughry was asked to contribute his paper. This was an unusually difficult and complex assignment, and we are grateful to him for his willingness to undertake it.

The epidemiology of the Arctic poses problems distinct from those normally encountered. This fact has been recognized by qualified investigators, and hence the presence of Dr. Babbott and Dr. Reinhard. These men have each spent extended periods of time studying the unusual facets that make arctic epidemiology so challenging. Their experiences, it must be borne in mind, deal primarily with indigenous populations living under conclitions potentially unrelated to those that might arise in a military emergency. Perhaps in the discussion it will be possible to obtain estimates of what might be expected under other circumstances and whether there are areas where further work is needed. It is 


\section{INTRODUCTION}

self-evident that knowledge gained from studies of native populations selected genetically through the centuries for life in the Arctic might conceivably have little applicability to the behavior of a population of greater size and cnncentration suddenly moved into this environment.

Cold is a stress. How much it results in a unique response by the body and the degree to which it resembles other stresses must be left to the physiologists for eluciclation. They have already established that acclimatization to cold entails greater heat production through an elevation in metabolic rate as judged by increased oxygen consumption. This is believed to be mediated through the enducrines in a highly complex, and as yet incompletely understood manner (Hart, 1958). These facts have pertinence for anyone interestea in host-parasite interactions because of the well documented contributions host metabolism makes to determining health or illness from an infectious agent. Dubos' book, The Biochemical Determinants of Microbial Disease, (1954), is a milestone, and since its appearance, numerous publications have expanded the literature.

Mammals exposed to cold can be expected to maintain normothermia unless there is excessive heat loss. Hypothermia is probably the consequence of too little heat proxiuction and too great heat liss. The investigator must constantly be prepareditodiscriminate, therefore, between effects in normothermic cold exposed animals and those found in hypothermic ccld exposed animals. The literature contains all too many examples of work in which these distinctions were not made.

The major question confronting us is: Does cold exposure influence detrimentally man's ability to combat infecticus cliseases? This question raises many more. What diseases? What men? How much cold and for how lnng? It is obviously difficult to answer these questions, particularly with man as the experimental subject, except for the most unusual circumstances such as those Sir Christopher Andrewes has used so imaginatively in his studies of the common cold. To a highly limited extent, it might be possible to utilize human volunteers for experimental infection with a few aiseases against which highly therapeutic agents are available. So far as I know, 
nothing of the kind has been attempted. Should it be done? Well might we provide the answer.

The uncertainties, the difficulties, and incieed the impossibilities of scientific experimentation with human beings in most research with infectious diseases forces the use of laboratory animals. There is ample precedence in the area of cold since a century ago when Pasteur reported his classical work with anthrax in chickens. The birds were resistant until chilled by a cold rain (Pasteur et al., 1878). In the intervening years the literature is adequate to prove that Pasteur's observations were not isolated findings. Other animals may or may not respond in modified for $m$ to infectious challenge, depending upon a number of variables, but there are sufficient examples to leave no room to doubt that host-parasite interaction is a plastic phenomenon under the pressure of certain environmental changes.

Confrontment with the established fact still leaves an enormous area for elaboration. When animals are known to become more susceptible to infection, there is always the question of why. It is axiomatic by now to offer certain tentative explanations. It can be said, for example, that the defenses of the host have been weakened. These include the humoral defense, the cellular defense, a weakening of the barriers to invasion, plus various combinations of them all. Even if there is evidence for change in any one of the defenses, it is still necessary to seek cut the basis for the change. It is also possible that virulence of the pathogen is enhanced. Without attempting to clefine virulence, agreement hopefully is assumed that it comprises many facets, any one of which maybecome primary in a particular situation. Again, it is desirable to understand the nature of the virulence change whenever it plays a role. There are, in adilition, somewhat more elusive concepts that can be reasonably offered to explain an elevation in host susceptibility. The in vivo environment on which pathogen proliferation depends, be it intracellular, extracellular, or both, can conceivably be enriched. There is less direct evidence for this than one would wish, especially for the bacteria, but virus multiplication is known to be intimately linkeri with the metabolic vigor of the parasitized cell. By contrast, the host might be put in the position of heightened sensitivity to the toxic manifestations of the disease state. 


\section{INTRODUCTION}

The success of any Symposium usually hinges on the participation of a few key individuals. One such person, in my judgment, whose early commitment as a participant undoubtedly influenced the acceptance of others, is Dr. Dan Campbell. He will lead the session this afternoon on the influence of cold on the immune response. Rather than give the impression of attempting to anticipate his remarks (which I would never presume to do), I am going to comment only briefly on this topic. Immunologists have refined their techniques to such a degree that they are the envy of many research biologists. Indeed, their methods have been applied wherever possible to problems fundamentally alien to those classically within the scope of their specialty. Immunology is quantitative biology at its best, and may possibly be considered the parent of molecular biology. To determine with a high degree of precision the level of response to antigenic stimulation does not necessarily make evident, however, the reason why one group of animals reacts differently from another. We can expect to learn more about these phenomena from Drs. I. L. Trapani and William Northey, who have been concentrating in this area of work for some years. It is a great pleasure to welcome not only them, but also one of two members of the group who make this Symposium international. Dr. Gosta Tunevall will speak first on the effects of hypothermia on the response of mice to bacterial toxins. This is one of four papers (two from Dr. Tunevall) dealing specifically with animals at reduced body temperature as it influences host-parasite interaction. The first is concerned with the important problem of how hypothermia alters the physiological or pharmacological properties of a soluble toxin. These bacterial products must exert their primary action at the enzymic level. If hypothermia reduces metabolic rate, as it must since the velocity of all chemical reactions is lowered by a drop in temperature, then there should be a less acute action of toxin in animals at reduced body temperature. As logical as this may seem, there are also other alternative effects that would make this untrue. Hypothermia, as it becomes more and more severe, affects different organs such that their activities do not change in parallel (Adolph, 1959). Physiological distortion occurs, compared to the integrated normal state, such that some functions cease at a temperature where others continue. Breathing may stop at about $15^{\circ} \mathrm{C}$, but the animal can survive and recover if artificial respiration is administered. Cessation of heart beat then becomes a cause of death in animals so maintained and 
further cooled. These facts have relevance only to serve as warnings against any attempt to generalize about the hypothermic influence on host-parasite interaction. The specific body temperature and its duration must be specified in reporting results, and conclusions can never be presumed generally applicable unless data are available to prove it.

The two sessions tomorrow will attempt to answer the question: Does cold predispose experimental animals (and man) to infectious disease, and if so, what diseases and under what conditions? We are unusually fortunate in having two of the world's authorities on infectious diseases to serve as moderators. I refer, of course, to Dr. Walter Nungester and to Sir Christopher Andrewes. Dr. Nungester has specialized primarily as a bacteriologist and Sir Christopher as a virologist. Their names must certainly be included in the special list of experts whose willingness to participate contributed so much in attracting to the Symposium such an illustrious group of participants. We are delighted to welcome and express our deepest gratitude to Drs. Miya, Previte, and Miraglia for the reports they are to give on work with bacterial diseases. We are equally fortunate in having such distinguished virologists interested in this area of research. I refer, of course, to the Drs. Walker, Metcalf and Sulkin, and to perhaps the most versatile of us all, Dr. Marcus, who is at home with both bacterial and viral diseases as well as with immunology.

A warning has been sounded against the pitfalls of generalizing from experiments with hypothermic animals unless sufficient knowledge justifies it. A similar warning must be issued in regard to cold exposure and change in susceptibility to infection. Differences in interpretation of results, differences in experimental design, and differences in findings are to be not only anticipated but desired. It is in this way that breadth of understanding is best acquired. But let us reflect a moment on some of the obvious difficulties in this type of work. At what temperature are the animals exposed? "Cold", according to the literature, can be anything from $15^{\circ} \mathrm{C}$ to $20^{\circ} \mathrm{C}$ down to refrigerator temperatures, about $5^{\circ} \mathrm{C}$, or deap freeze, $-10^{\circ} \mathrm{C}$ to $-20^{\circ} \mathrm{C}$, or it can be an arctic blizzard of $-45^{\circ} \mathrm{C}$. How long are the animals exposed? This can range all the way from continuous exposure, beginning with challenge, to an infinite varia- 
tion of intermittent exposures before or after infection. Are the animals cold acclimatized? One must ask how acclimatization is determined. Does it merely mean exposure for some time prior to infection, or is there some measurement employed that proves the animals are cold tolerant? Of greatest importance, in my judgment, are detailed descriptions of experimental conditions of the exposure to cold. Are the animals housed separately or in groups? Is bedding material provided? If they are singly housed, how much space is available? What is the velocity of air movement around the animals? Is relative humidity controlled, and if so, at what saturation? Are food and water continuously available? I confess as much ignorance about these matters as most anyone, yet a few preliminary experiments have clearly indicated that these factors cannot be ignored. Another consideration is illumination. Continuous dark, continuous light, or intermittent and erratic light are all to be avoided. Physiologists concerned with biological clocks or with periodicity in higher organisms have established beyond reasonable doubt that carbohydrate reserves, body temperature, endocrine secretion, eosinophile counts, and many others are all subject to highly significant variations from one time of day to another (Halberg, 1960). Some of these changes may be correlated with light, while others may show free-running periods not directly associated with detectable environmental phenomena. Space in which the animal is housed, cubic volume as well as area, may contribute in unsuspected degree to certain responses under investigation. The exigencies of space travel is making this an important object of study. Research in infectious diseases may be able to add something of significance to this work.

As moderator for our final session, it is a particular pleasure for me to welcome a very close friend of many years. We took several graduate courses together, our doctoral research was carried out in laboratories opening into the same basement corridor, we shared our frustrations and successes with one another, and we walked across the platfor $m$ the same hot June night in Texas more years ago than either of us cares to admit to receive our $\mathrm{Ph} . \mathrm{D}$. degrees. Dr. R. B. Mitchell has been the author of numerous scientific papers, and is now continuing his service to science through primarily administrative channels as Chief of the Department of Medical Sciences, School of Aerospace Medicine. 


\section{BERRY}

The final session contains the only paper on hibernation that is to be presented. Several participants suggested that someone concerned with this subject be invited, but most investigators are interested in the physiology of the hibernating animal. Little attention has been paid, however, to the fascinating possibilities such animals provide for the study of host-parasite interactions. Mr. Schmidt, who spent several years at the Arctic Laboratory, is a pioneer in this work and will, I am sure, be welcomed back to Alaska by his many friends.

The program is to be concluded by two men, Drs. Emil Blair and Colonel John Moncrief, who are really on the front line of the fight for knowledge about cold and infectious diseases. They have successfully used hypothermia as a therapeutic tool primarily against Gram negative infections in human beings. They are also applying their clinical experience to the design of animal experiments capable of elucidating some of the mechanisms involved in patient recovery. The significance of this work is evident, and we will be pleased to hear of the progress made in this applied field.

Before proceeding with the program, I want on behalf of us all to express our appreciation to the Arctic Laboratory for making this Symposium possible; to Mr. Robert Becker for the detailed arrangements he has made for our comfort and relaxation; to Mr. Alfred George of the University of Alaska for his travel arrangements; and to Dr. Eleanor Viereck for her editorial assistance, we voice our thanks. We are grateful to Major Sproul, Commandant of the Laboratory, for the hospitable accommodations he has provided for these sessions.

As you are aware, Colonel John D. Fulton is not here. This Symposium is his dream, and I hope it proves to be all he expected. He asked me to undertake its organization and has given at all times his fullest cooperation. If there are any omissions or deficiencies in the organization of the scientific program, they are mine and not his. 


\section{INTRODUCTION}

\section{LITERATURE CITED}

1. Adolf, E. F. 1959. Zones and stages of hypothermia. Ann. N. Y. Acad. Sci. 80: 288-290.

2. Dubos, R. J. 1954. Biochemical determinants of microbial disease. Harvard Univ. Press. Cambridge. 152 p.

3. Halberg, F. 1960. Temporal coordination of physiologic function. Cold Spring Harbor Symp. Quant. Biol. 25: 289-310.

4. Hart, J. S. 1958. Metabolic alterations during chronic exposure to cold. Fed. Proc. 17: 1045.

5. Pasteur, L., J. F. Joubert, and C. Chamberland.1878. La théorie des germes et ses applications à la medicine et à la chirurgie. Bull. Acad. de Med., Paris, 2nd Series. 7: 432-447.

6. Schneider, H. A. 1946. Nutrition and resistance to infection: the strategic situation. Vitamins and Hormones 4:35-70. 



\title{
DIFFICULTIES IN EPIDEMIOLOGICAL STUDIES OF THE RELATIONSHIP OF COLD TO HUMAN INFECTIONS
}

\author{
Robert I. McClaughry \\ Department of Medicine and Surgery \\ Veterans Administration \\ Washington 25, D. C.
}

ABSTRACT

This report deals with the difficulties experienced in an attempt to use Veterans Administration hospital records to determine the influence of cold on infectious disease. Various means were explored to find if exposure to cold of the members of the Armed Forces of the United States engaged in the Korean War influenced the occurrence and course of infectious diseases.

Scientific activity has risen exponentially in recent years. One result of this phenomenon has been the accumulation of a very large body of data. Dissemination of this information poses a major problem, which has been met in part by more scientific meetings and journals. Strange as it seems at times to a scientist trying to find time to get into his laboratory, data has been obtained faster than outlets for its reporting have developed. In absolute terms, there is no dearth of material to be discussed in scientific circles. These events have made the ever difficult and unpopular task of presenting negative results even more problematical. After all too lightly accepting exactly this assignment at this symposium, the full weight of what I had undertaken descended upon me. Justifying a negative report to this illustrious group posed a problem of no mean proportions.

I request your indulgence, therefore, for a brief description of the reasons for my appearance here today. It all dates back to the early summer of 1959, when the Chairman of the Division of Medical Sciences of the National Academy of Sciences - National Research 


\section{CLAUGHRY}

Council asked me to direct a survey of the medical research program of the Veterans Administration. In short order, I became acquainted with a strong opinion held by the then Administrator of Veterans Affairs, Mr. Sumner G. Whittier. He indicated that on the one hand there were the many Veterans Administration medical records, and on the other hand, there was the booming technology of electronic data processing. Now, to continue the paraphrase, if only a marriage of the two could be effected, surely answers to most important medical problems would be found.

The committee of medical scientists involved in the NRC study reached more circumspect conclusions from evaluating all the evidence available to them. Indeed, the final statement in the section on the use of computers in their report bears quotation in this context. "It is also to be noted that only very limited use can be expected of the medical records now in existence for retrospective studies, and that the collection of data bydesigning experiments for the use of computers should be the rule."

Despite this forewarning, which should certainly have been adequate, I fell into the trap of attempting a retrospective record study. In my defense, I can only say that the possibility of association of exposure to cold during the Korean campaign with differences in the incidence or course of infections seemed straightforward enough to merit a try by this method. I was also somewhat influenced by the consideration that such environmental influences on human infection have received relatively little attention, despite their importance.

The burden of my message is really very simple. It was completely impossible to establish from the records any group who were known to have been exposed to cold, or conversely to find a group similar except for such exposure. This information was simply not recorded. Furthermore, inference of the probability of of exposure to cold by identifying the military organization to which an individual belonged proved fruitless.

Since I am nearly as sensitive as was the fabled jackass which was struck a hard blow on the head with a singletree to get its attention, I wistfully gave up the record study at this point. Optimist that I am, though, I must add that the prospect appears better for 


\section{DIFFICULTIES OF EPIDEMIOLOGICAL STUDIES}

the success of a pre-planned epidemiological study of this question. From the perusal of medical records, it appears that a military population on maneuvers or in combat in a cold climate could be used for such investigations. It would be necessary to obtain definite information about the kind and degree of environmental exposure. Documentation of the diagnosis and treatment of various infections is now fairly standardized.

It is enough to indicate that I failed in the first approach to find a relation between exposure to cold and human infection, and that the information which was available may favor a different approach. To extend myself further would jeopardize my inherently unstable position by presuming to tell someone how his research should be done. For the problem passes from the range of studies possible with Veterans Administration records into the interest of those engaged in field studies.

Now, having spoken for about five of the forty minutes that the program allocated to this topic, I shall make my only significant contribution to this symposium by sitting down and making more time available for discussion of the substantive papers. 


\section{DISCUSSION}

MONCRIEF: I want to echo Dr. McClaughry's comments about retrospective studies, particularly clinical situations. They really have very little value because of the absence of the data that you are looking for in the clinical records. We have, I feel, probably one of the most exhaustive sources on clinical material and data collections anywhere in the country because we have a relatively small unit and a large number of personnel. Although a patient has been in the hospital two months and may have a clinical summary the size of a small telephone book, it still does not have the data in it we want in the future, and retrospective study is only valuable if the data that is contained in your records is positive; then it may be of some value. If it is negative, it may be that the doctor who made up the summary just left it out, or he may have observed it but did not put it down in the records, so the only thing you can say with retrospective study is whether something occurred. You cannot say it did not occur, nor can you say what you think occurred.

MARCUS: I think since Dr. McClaughry is dealing with negative results in terms of effect of exposure to cold on infectious disease, that we might ask him to comment about the subject of medical-surgical use of hypothermia which has, at least as near as I can make out from a very superficial inspection of surgical literature, also given negative results with regard to infections. Of course, there are circumstances involved here which, again, are mitigating in terms of preventing infection, but I still think it deserves some comment as an aspect of the negative results that you surveyed.

MCCLAUGHRY: I think we can have fun with the reports of Dr. Blair and Col. Moncrief. In a pre-planned study, it is possible to measure and record the amount of cold exposure, along with body temperatures, and then follow the incidence and course of infectious diseases. Also, the bacterial and viral flora of persons exposed to cold can be studied. 
MITCHELL: Dr. McClaughry, do you believe that the data are really not available, or that they have been in a language that is not translatable to your computer language? You are talking about a reporting situation in which the gaps may be far in excess of the words that you need to translate. A marriage between the reporting of physicians and the computer requires a single common language which permits little or no deviation.

MCCLAUGHRY: The data definitely are not available, since they were not recorded. Of course, the question of translation is also a stickler. Much of the present medical data would be classified by the computer people as "soft garbage", and little would be considered hard data. In recordings of blood pressure, for example, Dickinson Richards ${ }^{1}$ studied Bellevue Hospital records. No correlation was observed between the values found on the clinical charts, which were random measurements, and those measured under well controlled conditions.

Similarly, in a study done in Julius Comroe's laboratory ${ }^{2}$, an automatic blood pressure recording device gave entirely different blood pressure levels than those measured in the physician's office. There were patients who had been considered non-progressive hypertensive patients who, with the automatic recorders, were found to be normotensive.

BLAIR: I am particularly intrigued with the statement of the negative results of hypothermia, and I stress "hypothermia", not "cold exposure". These are two entirely different matters, of course, but we will have to decide with regard to infections whether or not hypothermia has a specific effect upon the organism involved or on the host himself, if he has any resistance at all.

MARCUS: I questioned some of our thoracic surgeons and found there were four in Salt Lake who engaged in the use of

2 Hinman, A. T., B. T. Engel, and A. F. Bickford, 1962. Am. Heart. J. 63: 663. 
hypothermia. They used both the external blanket procedure, and they used extra-corporeal cooling of the blood via the heartlung machine, and they also told me about the experiences of colleagues, Dr. Lewis from Chicago, and Dr. Duke and Dr. Swan of Colorado. They told me that invariably what these individuals in their own experiences encounter are physiological problems in their patients; problems involving blood clotting dyscrasia, cardiac arrhythmia, and so on.

They lower the temperature of their patients down to as low as $27^{\circ} \mathrm{C}$ using external blankets for six to thirteen minutes, and use multiple exposures of this type in carrying out their surgical procedures. Invariably, they were surprised when I asked them about infectious disease, and the four I spoke to all said, "Well, of course these patients are all covered by postoperative antibiotic treatment," but in no case were they concerned about postoperative infectious disease. I think you should know about that.

BLAIR: I am very much involved, in addition to my interest in bacteremic problems, in surgery. The fact does remain that we understand and know really very little about what hypothermia does under these circumstances of altering the environment of the bacteria. The University of Minnesota group has been interested; Fisher at Pittsburgh has studied the effects of cold upon so-called host mechanisms. Whatever mechanisms are concerned, we know that bacteria are cleared very readily after injecting and introducing a tremendous number of bacteria into the blood stream. Now, what this really means from the standpoint of the added insult and stress of surgery, anaesthesia and what-not, I don't know. However, purely from the standpoint of the rather emperical criterion of the progress of patients postoperatively, the incidence of infections postoperatively after the use of hypothermia is related only to the surgery. They have been traced without difficulty to errors and faults with reference to techniques in surgery, which all surgeons should know a lot better about, of course. Infections have also been traced to the machinery in using extra-corporeal systems of cooling. 
Granted, these are purely a matter of observation. And then with surgeons in our position, one of the most important tools is the ability to look at things from the standpoint of their clinical judgments. At the University of Maryland, Division of Neurosurgery, in the past year almost two hundred patients have been cooled. They are cooling as many patients as we are in cardiovascular surgery, and appear to be our staunchest competitor; the instance of infections is no greater. This is not good scientific evidence, but insofar as taking care of patients is concerned, it does appear that cooling for periods up to about two or three hours to levels of approximately $20^{\circ} \mathrm{C}$ to $30^{\circ} \mathrm{C}$ does not increase the incidence of infection following surgery.

MONCRIEF: How about the incidence of infection following profound hypothermia of $10^{\circ} \mathrm{C}$ ?

BLAIR: The unfortunate fact does remain that the incidence of infection following the use of profound hypothermia which requires a mechanical set-up to cool a patient down this low, does result in a higher incidence of infection than if the patient were simply cooled. Whether this is related to the fact that the patients are cooled to the very profound and potentially lethal levels per se, or whether it is due to the fact that it takes a lot of equipment, we really don't know.

In fact, it does remain that no matter how carefully and how rigidly Lister's ideas are employed today, after an ordinary elective surgical case, if you culture very carefully the surgeon's hands, the instruments, and the nearby drapes, you will always find bacteria in staggering and distressing amounts. But these patients do not develop postoperative infections.

The question remains relatively unanswered, and the only thing I might say about this is that the patients are kept at these profound levels for a very, very brief period of time. In many instances, it does not exceed more than one hour; occasionally two hours. At the University of Maryland -- I guess we were a young, immature group trying to learn -- this is the excuse we give for the fact that we had cooled some patients down to levels of $5^{\circ} \mathrm{C}$ for periods of about two hours. These were children. 


\section{CLAUGHRY}

They all survived because they were children. Their natural homeostasis was very kind to us.

BERRY: How much adrenal response is there in these patients?

BLAIR: The adrenal response is reduced. Again, this is the difference between induced hypothermia and cold exposure. This is related, of course, to the type of anesthesia used. These people, you know, are all anesthetized. If a barbiturate anesthesia is used, the response of the adrenals is reduced tremenduously. Ether anesthesia invokes an increased response for a period of time, but when the patient and the animal are cooled, then the circulating cortico steroid and catecholamines are very much lowered. Hypothermia allays stress response.

BERRY: In other words, hypothermia is almost anti-stress?

BLAIR: That is correct, as opposed to cold exposure.

BERRY: I think these are very important distinctions that we should keep in mind.

MITCHELL: Dr. Blair, where are your prime heat sinks for retaining heat calories in these bodies once you start cooling? You take them down with cooling to $20^{\circ} \mathrm{C}$ and you maintain this for quite a time. You are now ready to work and you have some tissues there that are rather tremendous heat sinks. They remain warmer, let's say, and then if you move past that to these colder temperatures, do you overcome the ability of that tissue to resist, or do you make it more susceptible, and wherein do you get these infectious processes originally? I am trying to figure out how you approach this.

BLAIR: Are you referring to the instances of cooling either animals or patients down to profound levels in the absence of infections to begin with? Is this what you mean?

MITCHELL: Yes.

BLAIR: First of all, with regard to heat production during 
the induction of cooling, the fact is, of course, that the human being, himself being a heat exchanger and a very inefficient one in many respects, produces a series of problems outside of the infection which have resulted in very serious consequences, sometimes death, and this is because the specific heat of the various tissues are so different. When I say artificial cooling, I am referring to hypoxia in the systems. When a patient is cooled down, he winds up with some very serious gradients in various tissues, the most serious of which is skeletal muscle. The skeletal muscle is not cooled down very much. It is kept quite warm, as a matter of fact. The liver is cooled down quite considerably; also the brain. The net result is that when the cooling process is stopped and the patient is presumably stabilized at a particular level of hypothermia, and this is usually guaged by the esophageal temperature, we begin working on the patient. Of course, a lot of other things are going on, particularly, I think, in the skeletal muscle, which when we start to rewarm the patient, results in a metabolic situation which has made us very, very unhappy; and this is the metabolic acidosis.

Now, I am off the subject that you had raised, Dr. Mitchell. With regard to infections per se, I am not aware of any. They probably have developed and I can only reiterate the attempts of culturing the equipment and, of course, the patient's blood stream, but we have not found any bacteremia. The bacteria, if present, would become overwhelming. This is a matter which would require serious investigation, but then, I personally am not terribly concerned about it because of the time factor. I don't think much is going to happen in one or two hours. These patients are cooled to $10^{\circ} \mathrm{C}$ in about twenty minutes. They are warmed in about forty-five minutes, but time factors are very short, and I can assure you that the deep level cooling maintained is very brief. Attempts to assay host mechanisms have demonstrated that the period of cooling and rewarming has not produced any longstanding effect on the host mechanisms in handling bacterial infections.

CAMPBELL: The anesthetic must play quite a role here, as in allergic reactions which do not occur during anesthesia. 
BLAIR: Yes, anesthesia, of course, is a two-edged sword. We are not dealing with hypothermia per se in its native true state by any manner of means. We are dealing with modified hypothermia or, if you will, modified anesthesia, and this is because in reference to anesthesia, it is necessary to anesthetize both humans and experimental subject to a rather deep level. We call this surgical anesthesia, and this is the level primarily at which the reflex mechanisms responsible for maintaining homeothermia are depressed. They have to be depressed. The only instance of which I am aware and in which hypothermia is produced in the absence of anesthesia is in patients who have been treated with hypothermia for bacteremic shock and other problems of that nature, and again I will touch upon that later. These people, of course, are not anesthetized.

MARCUS: Do you treat them with morphine or anything to allay their pain?

BLAIR: Our only experience in this regard, Dr. Marcus, has been with individuals whom we have considered to be refractory to the standard therapy. In the judgment of the physician, these are individuals who have become refractory to very intensive therapy in bacteremic shock; these people are usually comatose. Their reflexes are markedly depressed, and these people are cold. It has been very unusual to observe shivering. As a matter of fact, we use shivering as an index as to when to rewarm the patient. It is a sign that the patient is getting better.

MCCLAUGHRY: Dr. Campbell may have indicated one of the very important possibilities here; namely that combining anesthesia with hypothermia may make it possible to sort out some of the factors in pathogenesis of some infectious diseases. In particular, it may provide a means of studying host responses to stress, which are really protective mechanisms, but which may become deranged.

BLAIR: These studies are under way, I might add. Through a contact with the United States Army, the University of Maryland has recently established a clinical shock unit which is devoted to treatment of shock, including bacteremic shock, and one 


\section{DIFFICULTIES OF EPIDEMIOLOGICAL STUDIES}

of the purposes is to investigate these properties we are talking about and about which we really know so very little, particularly in the human.

MCCLAUGHRY: It occurred to me, also, that your description of the situation of the patient with bacteremic shock also bears on this question of stress, because bacteremic shock is one of the things which suppresses those functions. In one sense, you have the anesthesia, anti-shock, and the anti-stress state established by physiological and pathological mechanisms.

BLAIR: That is quite right. It is the pathologic state, the comatose state, essentially. The only thing I am interested in, of course, is controlling the reflex mechanism; that is, shivering. In elective situations, we use anesthesia to depress this, and, of course, anesthesia is a tremendous poison. It poisons a lot of things besides the skeletal muscles.

SCHMIDT: I would like to make reference to some work we did here in Alaska. Our original aim was to determine the incidence of respiratory disease here at Ladd Air Force Base. We had about two thousand subjects. It occurred to us that it might be possible to investigate the influence of cold exposure on the incidence of infection. Accordingly, in taking the histories on these men, we started by asking them if they worked outside or inside. This approach proved to be of little value, because even though their duty stations might have been outside, the men were clothed to the extent that they could not be considered to be cold exposed in the sense of being chilled. We eventually grouped the men according to their squadron activities, thinking that cooks and bakers, for instance, would be less likely to encounter cold exposure than would field maintenance crews. About one third of the 1,985 men studied were in squadrons which we considered would have a higher exposure index. We were unable to demonstrate any significant difference in the incidence of upper respiratory infection attributable to cold exposure. I think we ran up against a stone wall in trying to determine, with any degree of certainty, whether these men were actually cold exposed. 
BABBOTT: In an AFED report of two or three years ago on winter maneuvers in arctic areas, they reported a great many more cases of heat exhaustion than they did frostbite; so even under field conditions it is very difficult to evaluate cold exposure.

ANDREWES: Williams and Lidwell carried out some experiments on post office workers in Britain, and in comparing those people who were delivering mail out of doors with those who were working indoors, the incidence of respiratory infection was rather greater in those who were working indoors, but of course you can't draw very many conclusions from that because they were so much more exposed to other people, and the outdoor people had very little such contact.

MIRAGLIA: There are several reports in the literature that indicate that people that work indoors and go into cold rooms-butchers, for example--do have a higher incidence of sinusitis and middle ear infections. Taylor and Watrous ${ }^{3,4}$ made studies of this using very small groups of individuals, and there are some examples in Spanish literature which have approximately the same data, but as some of us have already indicated, there are other bits in the literature that seem to contradict this, or at least I found evidence to the contrary.

BLAIR: The matter of respiratory infections, of course, has risen in regard to hypothermia per se in patients and there has been an occasional report of patients who have been cooled who developed pneumonia, but these have been incredibly rare, and $I$, in the years that I have had the privilege of working in this particular area, have never seen respiratory infection in a patient who has been cooled. As a matter of fact, we have cooled patients who have had pneumonitis of one kind or another and have observed it clearing up during the process of cooling. Of course, these people are receiving antibiosis in treatment, but the hypothermia is not retarding the clearance 


\section{DIFFICULTIES OF EPIDEMIOLOGICAL STUDIES}

of the respiratory infection, in any event.

MITCHELL: You are speaking about hypothermia, and the other people have been talking about cold exposure, and it turns out that people exposed to cold up here may be more likely to suffer from heat exhaustion than from cold, and I wonder, maybe, if we should instrument a few people and put them out in the cold.

DRURY: Captain Veghte has considerable data on body temperatures during cold exposure.

MITCHELL: I imagine that there is more stress in thinking about having to go on one of those maneuvers than there is in the experience.

MONCRIEF: In reference to Dr. Marcus's question to Dr. Blair about incidence of infection with induced hypothermia, Dr. Blair mentioned the fact that it is the individuals who have the hypothermia induced by the extra-corporeal circuit that have the increased incidence, if there is any. I think infection is directly proportional to the number of couplings and number of instruments that you have the patient hooked up to; and this, I think, is very well pointed out in our normothermic patients when we put on an extra-corporeal circuit such as extra-corporeal hemodialysis for renal insufficiency.

REINHARD: I am impressed by the fact that the conversation of the last hour has moved us into an area that looks somewhat like a bucket of worms, and I wonder whether or not we are trying to sum up before we have ever heard what each person has to contribute. 


\title{
ASPECTS OF ARCTIC EPIDEMIOLOGY
}

\author{
Frank L. Babbott, Jr. \\ University of Pennsylvania \\ School of Medicine \\ Philadelphia 4, Pennsylvania
}

\section{ABSTRACT}

Few human pathogens found in arctic populations are localized to this geographic region, although some parasites may have a restricted distribution coinciding with that of their intermediate hosts. The variety of infectious agents is more limited than in temperate or tropical climates. With respect to spread, short chain personto-person transmission appears more important than dissemination by vector or vehicle. The age distribution of cases and the clinical response of a particular ethnic group to a given disease can usually be explained on the basis of past exposure. Under conditions of normal arctic living, there is little evidence that low environmental temperatures directly affect the ability of the human host to react to antigenic stimuli. Rather, in the Eskimo village, cold is important because of its indirect effect on the way people live.

Epidemiology has been defined as a study of the distribution and determinants of mass disease, or disease as it affects populations. Consequently, our focus is not primarily on the cellular manifestations, nor even on diagnosis and treatment of the individual patient. And yet, we must understand pathogenesis, as well as the clinical picture, if we are to unravel the determinants of the disease as it behaves in populations.

Of course,cold, as a physical agent, can and does directly affect individuals and groups of people. During World War II, cold alone, or cold combined with wet, resulted in the hospitalization of $91,000 \mathrm{U}$. S. Army personnel in all parts of the world. Seventy-one thousand cases of cold injury occurred in the European Theatre, mostly during the winter of 1944-1945 (Whayne, 1958). At one time in the winter of 1943, frostbite injuries in United States heavy-bomber crews accounted for more casualties than all other causes combined. Gunners in B-17 and B-24 aircraft were especially at risk as they maneuvered machine guns through open"waist ports" while flying at 25,000 to 35,000 feet in temperatures ranging between $25^{\circ} \mathrm{F}$ and $45^{\circ} \mathrm{F}$ below 


\section{BABBOTT}

zero (Davis, 1943). As you realize, the resulting disability was often permanent, with loss of fingers, toes, or even a whole foot. Less severe cases required hospitalization ranging from a few days to many months. So there can be no doubt about the importance of direct injury by short-term exposure to cold, especially in military populations.

But a long-term direct effect of environmental temperature on evolving races of man has also been postulated. Howells points out that ethnic groups arising in the warmest and coldest climates seem to have developed a physique and body mass which permits the maximal dissipation or conservation of heat (Howells, 1960). He contrasts the large surface area of the Sudanese tribesman with the squat, compact build of the pure-blooded Eskimo, and discusses the advantages of each with respect to the physiologic demands of his immediate surroundings. Thus, cold seems to have a direct effect not only on men as individuals, but even on the development of the race itself.

However, the purpose of this symposium is not to discuss cold injury per se, but rather to explore some of the more subtle influences of cold on infectious agents and host responses. In the laboratory, as we will be hearing, it is possible to raise animals, infect them and measure their reactions, all under hypothermic conditions. Likewise, we may propagate the agent at any point on the temperature scale compatible with its survival. Yet Dr. McClaughry has just pointed out the difficulties encountered when we try to undertake similar observations on human populations living in a setting rampant with uncontrolled and even unrecognized variables.

Part of the trouble is that under natural conditions, both men and infectious agents do their best to avoid the less than optimal environment imposed deliberately in the laboratory. We can set up an experimental hypothermic stress and force mice to a compensatory physiologic adaptation, one manifestation of which may be a reduced capacity to resist infection. But when it gets cold at Wainwright or Fort Yukon, the inhabitants merely put on an extra parka or add more fuel to the stove. Only occasionally is a hunter caught on an ice floe or an airman down on the tundra in circumstances where he experiences the same sort of stress required of the laboratory 


\section{ARCTIC EPIDEMIOLOGY}

mice. Likewise, bacteria and viruses grow best within a rather narrow temperature range, although low ambient temperatures may promote survival. If they are human pathogens, they usually prefer an environment close to $37^{\circ} \mathrm{C}$. Fortunately for these organisms, they are seldom forced to adapt to lower temperatures, because their human culture medium does everything possible to maintain thermal homeostasis, regardless of external conditions.

Between 1954 and 1957, I was part of a group under the sponsorship of the Armed Forces Epidemiological Board looking into the transmission of shigella and salmonella infections in various parts of the Arctic. Frequently when hearing of our studies, people would ask how these bacteria withstand such an inhospitable climate. Our answer was that shigella and salmonella grow and multiply at $37^{\circ} \mathrm{C}$, and people who inhabit the Arctic maintain the same body temperature as that of their distant relatives in better known parts of the world.

This does not mean that there are not both obvious and unrecognized physiologic responses to cold which may well have a bearing on infectious illness. I am thinking of such things as blood flow and secretory activity of the upper respiratory tract and certain endocrine responses. However, those of us morefamiliar with field than experimental laboratory studies have hesitated to attribute such unique features as we see to agents evolved under hypothermic conditions or to hosts which have been forced to endure physiologic stress from cold. Rather, if pressed, we are apt to point to such secondary effects of cold as overcrowding within dwellings or permafrost which hinders sanitation. Hopefully, following this conference, our horizons will have been broadened to include more subtle influences which we were previously unable or reluctant to recognize.

\section{AGENTS OF DISEASE IN ARCTIC POPULATIONS}

It is convenient, and I believe justifiable, to think of mass disease 


\section{BABBOTT}

as having three components: the agent, the host population, and the environment. In other words, multiple factors inevitably enter into causation. The task of the epidemiologist is todetermine the nature and relative importance of thesefactors, sothat we may know where to apply control measures most effectively.

I would like to talk briefly and in very general terms about some aspects of these three components of mass disease as they relate to the Arctic, and we might begin with a consideration of infectious agents. The first point to be made is that very few human pathogens are strictly localized to arctic areas.Of course,northern populations have been studied less intensively than residents of other regions, and yet I doubt if a totally new bacterium or virus having man as its primary host will be isolated from these people. The same cannot be said with equal confidence for parasites, however, because their life cycles sometimes include intermediate hosts unique to norther $n$ latitudes. The second point I'd like to make is that the variety of infectious agents thus far encountered in the Arctic is limited, at least by temperate and tropical standards. This is hardly unexpected, since the same observation applies to arctic flora and fauna generally (Polunin, 1955; Bliss, 1962).

During our intestinal disease studies in Alaska, Greenland, and Lapland, some 4,200 people were examined bacteriologically. Only four types of shigella and five types of salmonella were identified, and all were familiar pathogens. The greatest variety came from a couple of Alaskan village populations which included only 325 people. Among nearly 2,000 well Greenlanders surveyed, the sole pathogenic bacteria found were $\underline{\mathrm{Sh}}$. sonnei in three carriers and $\underline{\mathrm{S}}$. paratyhi $\underline{\mathrm{B}}$ harbored by four others (Gordon, 1959). Except for one trematode, Cryptocotyle lingua, the parasites identified in stools of 660 West Greenlanders were well recognized inhabitants of the human gastrointestinal tract. These included E. coli, Endolimax nana, Gardia lambia, Chilomastix, and, surprisingly enough, Entamoeba histolytica in some 16 per cent (Babbott, 1961).

Hildes and his colleagues (Hildes, 1958, 1959) have carried out serologic surveys in the Canadian Arctic, and Dr. Reinhard will speak shortly about similar work here in Alaska. The agents they identified - poliomyelitis, Coxsackie virus, psittacosis, ECHO virus, 


\section{ARCTIC EPIDEMIOLOGY}

herpes simplex, influenza and adeno-viruses, to name several - were the same as one, might find in many other parts of the world.

But if we are dealing with familiar agents of disease, we are also dealing with agents which may be responsible for widespread sickness and death. The impact of imported illness among Indians and Eskimos is a sad story, and one we hardly have time to document this morning. Suffice it to say that in the 19 th century, waves of smallpox, typhoid fever, pneumonia, meningitis and measles swept through susceptible arctic populations, and tuberculosis has been endemic at a high level for decades. In fact, it is only within very recent years that accidents have replaced tuberculosis as the primary killer. Currently, accidents account for approximately a quarter of total deaths in the Eskimos of Alaska and Greenland (Alaska Health Dept., 1962; The State of Health in Greenland, 1959).

As a measure of life threatening forces, you might be interested in a few comparative statistics. In 1959 , the mortality rate for Alaskan natives was 9.7 per 1000 population and for Greenlanders, 10.3 per 1000 (Alaska Health Dept., 1962; The State of Health in Greenland, 1959). This is close to the 9.3 per 1000 experienced by the white population of continental United States, or "the lower 48", as Alaskans call it. The birth rate for Alaskan natives that same year was 47.7 per 1000, and for Greenlanders, 51 per 1000; more than twice as high as the birth rate among whites in continental United States (23.1 per 1000). Taken together, the current birth and death rates mean that close to 40 people are being added to each 1000 in the population each year, thus giving Greenland and Alaska one of the highest rates of natural increase in the world. If this annual four per cent increase is maintained, the population will double in less than eighteen years. Considering limited arctic resources, and especially the limited locally available food supplies, it is obvious that the growing population will be more and more dependent upon goods and services brought in from outside.

We will hear much pertinent information about the influence of environment on disease agents in the coming sessions. Under natural conditions in the Arctic, a human pathogen, to survive, must either complete its life cycle within the body of man or some other warm blooded animal, or the agent must be able to withstand exposure to 


\section{BABBOT T}

cold. Included among sensitive pathogens not having an animal reservoir are the gonococcus, pneumococcus, and many respiratory viruses. Trichinella and echinococcus typify parasites having an intermediate host, as does rabies, an importantdisease in the arctic setting.

Dr. Reinhard will have considerable to say about the survival of viruses, but as examples of nonviral agents resistant to environmental stress, we usually think of spore-formers or encysted protozoa. Among the spore-formers, Clostridium botulinum, type E, presents an important health problem for Eskimos living along the Bering Sea and northern Labrador. Spores deposited in ocean silt may contaminate marine mammals and subsequently propagate in improperly stored meat, such as seal flippers. Between 1945 and 1960, 44 human cases and 23 deaths were reported (Dolman, 1960). However, studies have shown a rapid die-off of cysts of Endamoeba histolytica at temperatures below freezing (Chang, 1954). Although we don't usually regard enteric bacteria as particularly hardy organisms, investigators from the U. S. Army Environmental Health Laboratory conducted some interesting experiments in Fort Churchill, Canada, using fecal samples seeded with $\underline{\text { S. typhi }}, \underline{\text { S. paratyphi }}$ B, and Sh. sonnei (Human Wastes, 1954). These were placed at tundra sites, and recultured periodically from December to July. Sh. sonnei

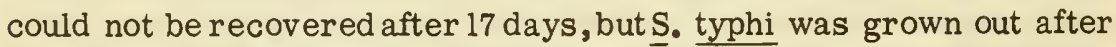
45 days and $\underline{S}$. paratyphi $\underline{B}$ after 135 days. The recovery period for these salmonella organisms was evenlonger in feces from carriers. They had survived, but not multiplied.

It might be appropriate here to mention modes of transmission under arctic conditions. Summed up briefly, it appears that short chain, person-to-person dissemination is more important than complex, vulnerable spread involving vehicles, vectors, or extrahuman reservoirs. Certainly the latter exists, as exemplified by prevalent diseases such as rabies, trichinosis (Thorborg, 1948; Connell, 1948; Bradly, 1950), echinococcosis (Rausch, 1954), diphylobothriasis, and tularemia (Philip, 1962). However, where bacterial intestinal infections would commonly be transmitted through food and water in other parts of the world, these illnesses in the Arctic present an epidemiologic picture much more consistant with contact spread (Gordon, 1959 ; Fournelle, 1959; Gordon, 1961). The same 
goes for the enteroviruses which Dr. Reinhard will discuss shortly. As a group, respiratory afflictions, both viral and bacterial, are very important, and of course are spread by contact. In terms of mortality for Alaskan natives in 1960, influenza and pneumonia ranked second only to accidents. Tuberculosis and bronchitis were also among the first 10 causes of death (Alaska Health Dept., 1961).

Thus, we may conclude that while the variety of infectious agents is limited, the organisms are, in general, very similar to human pathogens isolated elsewhere. With regard to transmission, short chain person-to-person spread appears at present to be more important than dissemination by vector or vehicle.

Because much detailed attention will be given toagents of disease, I would now like to mention a few factors involving the host.

\section{SOME HOST FACTORS IN DISE ASE OF ARCTIC POPULATIONS}

Disease in any population may be described in terms of certain host characteristics. One of these is the race or ethnic background of the people under study. At least until very recently, tuberculosis in Eskimos has behaved rather differently than itdoes in Caucasians. Prevalence was high, and as of 1957, 30 per cent of adults living in the Yukon-Kuskokwim delta region of Alaska had X-rayevidence of past or current pulmonary involvement (Comstock, 1959). The disease ran a much more acute, oftenfulminating course, with many extrapulmonary lesions (Schaefer, 1959). It is interesting to note that Negros in continental United States used to exhibit a similar response to tuberculosis (Pinner, 1932), as did Senegalese troops during World War I, living in the same military environment as their French cohorts (Borrel, 1920).

Of course it is often difficult to differentiate between innate host factors of resistance and environment as it influences exposure, particularly when we study human populations. However, Lurie has shown significant family variations in tuberculosis susceptibility 


\section{BABBOTT}

among rabbits receiving an identical dose of the bacillus (Lurie, 1941). It does not seem unreasonable to postulate a similar diversity of nonspecific resistance for the human animal, even if it is more difficult to demonstrate. In terms of species survival, it is to the advantage of both host and parasite that they live in relative symbiosis. The long-term process of natural selection tends to evolve such a relationship. But regardless of whether one puts emphasis on host or environmental factors in explaining observed differences in disease behavior, it is important to consider and specify all possible attributes of the population under study, including ethnic background.

Age is a second host characteristic, and we often find an unexpected age distribution of cases, especially when infectious illness appears in isolated arctic communities. For example, measles was imported by a Danish sailor to the vacinity of Julianehaab, Greenland, in 1951. (Christensen, 1953). An attack rate of 99 per cent resulted, not just among children, but throughout the general population. Only the very elderly were spared in appreciable numbers, indicating that no measles had occurred in this community in more than sixty years. Likewise, it has been possible to reconstruct the past history of mumps, poliomyelitis and influenza here in Alaska by relating antibody titers to the host characteristic of age (Philip, 1959 ; Reinhard, 1960 ; Philip, 1962).

Of course, a very important component of host resistance is the presence of specific antibody, which presupposes prior contact with the antigen. I will speak shortly about the arctic environment as it promotes or inhibits such contact. But let me return for a moment to a point we touched on earlier; that is, under conditions of normal arctic living, we lack epidemiologic evidence to show that low environmental temperatures directly alter the man's ability to respond to an antigenic stimulus. On the contrary, the Alaska Department of Health and Welfare does not differentiate between the Indians of Southeastern Alaska and the Eskimos of Northern Alaska when planning an immunization program, nor do they expect resulting levels of immunity to differ from those seen in continental United States (Pauls, 1962). Likewise, serologic studies following natural infection fail to demonstrate deviation from an expected distribution of antibody titers (Philip, 1959; 1962; Reinhard, 1960). 


\section{ARCTIC EPIDEMIOLOGY}

The reason for this uniformity in host response under natural conditions appears to be that residents of Barrow or Thule or arctic Lapland so modify their microclimate that they seldom suffer physiologic stress from cold, although they are susceptible to some of its secondary effects.

In the time remaining, I would like to mention briefly certain features of the arctic environment.

\section{ENVIRONMENTAL FACTORS IN DISEASES OF ARCTIC POPULATIONS}

The geographer defines the Arctic as that portion of the northern hemisphere lying within the Arctic Circle, which falls at $66^{\circ} 30^{\prime}$ north latitude. This marks the southernboundary of territory where at least one day each summer the sun never dips below the horizon, and one day each winter it never appears. The characteristic types of terrain are tundra, usually bordering the coast, taiga or inland forested regions, and glacial topography typified by the Greenland ice-cap and parts of the Canadian archipelago.

The climatologistdefines the Arctic as that territory lying within the $50^{\circ} \mathrm{F}$ isotherm, an imaginary line whichbounds an area where the average temperature during the warmest month of the year does not exceed $50^{\circ} \mathrm{F}$.. To the agronomist, concerned with crop potential, the number of frost free days a year is much more important than minimal winter temperatures.

Permafrost is one physical feature of the arctic environment which influences distribution of disease. Obviously when the earth is permanently frozen, subsurface excreta disposal is difficult or impossible, and water must be procur ed from easily polluted surface sources. A more indirect, but significant affect of permafrost is the restriction it places on agriculture. People inhabiting such an area must rely upon a hunting or fishing economy with its attendent lower standard of living, unless, of course, military establishments or 


\section{BABBOT T}

industry, such as mining, are available to provide employment.

There is no doubt that cold influences disease behavior in arctic populations, but as I indicated, we have little evidence that under natural conditions, cold of itself directly affects agent pathogenicity or host resistance. Rather, it is important because of the way it modifies the social environment or the way people live. For example, houses must be heated ten or eleven months of the year. Fuel is expensive in terms of either the money or the effort required to procure it. To conserve heat, dwellings are small with consequent overcrowding, and thus conditions are ideal for transmission of respiratory illness.

Studies in other areas have shown that the incidence of enteric disease is influenced more by the availability of water in adequate quantities than by its purity (Hollister, 1955 ; Schliessman, 1958). Because of the cold, people in arctic regions depend for many months each year on melted ice or snow for their water supply, and this again requires the expenditure of precious fuel. It is not surprising, then, that the level of sanitation is low, and fecal-oral spread of intestinal organisms is easily accomplished. Yet with respect to bacterial enteric illness, low environmental temperatures also serve a useful purpose in that bacterial pathogens are immobilized and killed off in large numbers, anci spread by flies is greatly minimized. Cold appears to promote survival, if not multiplication, of viral agents, as Dr. Reinhard will point out.

Another indirect effect of cold on arctic disease has been the limitations it has imposed upon travel until relatively recently. Hialf a century ago, the inhospitable environment served to protect people from imported pathogens. Now, there are few, if any, communities which experience prolonged isolation. Fortunately, improved communications brings not only more conventional patterns of disease, but also preventative and therapeutic services as well. Therefore, it is highly unlikely that we will see epidemics of the magnitude or severity which characterized the Eskimos' early contact with the outside world. As I have mentioned, death rates among Alaskan natives currently approximate those of their fellow citizens elsewhere. Our problem in the future is not to lower death 
rates, but rather to raise living standards, and this task is not made easier by the rapid population increase.

In closing, I would like to touch upon a few features of the biologic environment. If this meeting had been called in June, we would have been very much aware of the high mosquito density which characterizes an arctic summer. Surprisingly enough, mosquitos have yet to be implicated as disease vectors in this part of the world, though the possibility requires further study, with particular reference to the ARBO viruses. As for animal reservoirs, Hildes and his group at the University of Manitoba, conducting serologic surveys in the Eastern Canadian Arctic, found 15 per cent of 241 Eskimos possessed complement fixing antibodies to psittacosis (Hildes, 1958). Although cross reactions with other viruses, especially trachoma and inclusion conjunctivitis, must be con'sidered, it is very possible these people contacted psittacosis as a result of eating raw birds. I have already referred to trichinosis, echinococcosis and rabies, all of which have mammalian reservoirs. Within recent years, brucellosis has been discovered in both men and reindeer of the Soviet and American Arctic (Cherchenko, 1961; Edwards, 1959 ; Huntley, 1962).

Finally, to illustrate the importance of understanding arctic ecology, let me mention a Strontium-90 survey conducted here in Alaska with the help of Colonel Fulton (Schulert, 1962). Because of permafrost, radioactive fallout from Soviet nuclear testing accumulates on the surface of the soil where mosses, lichens and other low vegetation grow. These plants provide forage for caribou. A study of caribou antlers in Alaska revealed a concentration of Sr-90 more than ten times that of pooled deer antlers in California. Eskimos in certain areas eat large quantities of caribou, and urine assays in these communities showed that new bone was being laid down with about $12 \mu \mu \mathrm{c}$ of Sr-90 pergram of calcium, which is four times the average $U$. S. concentration. This single problem required the interrelating of knowledge concerning meteorology, geology, botany, anthropology, animal ecology, and radiobiology. 


\section{BABBOT T}

\section{SUMMARY AND CONCLUSIONS}

In the short time available, it has been possible to touch upon only a few features which characterize the behavior of human disease in the Arctic. In briefest summary, let me recapitulate:

1) Few human pathogens found in arctic populations are localized to this geographic region, although some parasites may have a restricted distribution coinciding with that of their intermediate hosts.

2) The variety of infectious agents is morelimited than in tropical or temperate climates.

3) With respect to spread, short chain person-to-person transmission appears at this time more important thandissemination by vector or vehicle.

4) The age distribution of cases and the clinical response of a particular ethnic group to a given disease can usually be explained on the basis of bast exposure.

5) Under conditions of normal arctic living, there is little evicience that low environmental temperatures directly affect either agent virulence or specific host responses. Rather, in arctic populations colci is primarily important because of its incirect effect on the way people live.

I do notbelieve there is such an entity as "arctic medicine", if by that we mean a unique set of patholngic conditions restricted to this geographic region. However, the ecclogy of the Far North is ristinctive, and may alter the epidemiology of certain ciiseases. If an illness is to be effectively prevented or controlled, it is important that we unierstand nct only its laboratory and clinical characteristics, but also its behavicr in populations. 


\section{ARCTIC EPIDEMIOLOGY}

\section{LITERATURE CITED}

1. Alaska Department of Health and Welfare. 1962. Bureau of Vital Statistics. Personal Communication.

2. Babbot, F. L., Jr., W. W. Frye, and J. E. Gordon. 1961. Intestinal parasites of man in arctic Greenland. Am. J. Tropical Med. Hyg. $10: 185-190$.

3. Bliss, L. C. 1962. Adaptations of arctic and alpine plants to environmental conditions. Arctic 15: 117-144.

4. Borrel, A. 1920. Pneumonie et tuberculose chez les troupes noires. Ann. Inst. Pasteur 34: 105-148.

5. Bradly, P. J., and R. Rausch. 1950 . A preliminary note on trichinosis investigations in Alaska. Arctic 3: 105-107.

6. Chang, S. L. 1954. The survival of cysts of Endamoeba histolytica in human feces under low temperature conditions. Annual Report, Commission on Environmental Hygiene, Ar med Forces Epidemiological Board 1953-1954.

7. Cherchenko, I. I. 1961. Brucellosis in arctic regions. I. On brucellosis in reindeer. Zh. Mikrobiol. 32: 135-159. J. Microbial, Epidemiol. Immunobiol. 32: 554-559.

8. Cherchenko, I. I. 1961. Brucellosis in arctic regions. II. On epidemiologic characteristics of a focus of brucellosis in reindeer. Zh. Mikrobiol. 32: 118-123.

9. Cherchenko, I. I., and N. I. Samsonova. 1961. Brucella infection in far northern regions. III. Clinical manifestations of "reindeer" brucellosis in man. Zh. Mikrobiol. 32: 5l-56. 
10. Christensen, P. E., H. Schmidt, H. O. Bang, V. Andersen, B. Jordal, and O. Jensen. 1953. An epidemic of measels in Southern Greenland, 1951. Measles in virgin soil. II. The epidemic proper. Acta Med. Scand. 144: 430-449.

11. Comstock, G. W., and M.E. Porter.1959. Tuberculin sensitivity and tuberculosis among natives of the lower Yukon. Pub. Health Rep. 74:612-634.

12. Connell, F. H. 1948. Trichinosis in the arctic-a review. Arctic 2: $98-107$.

13. Davis,L., J.E. Scarff, and M.Dickenson. 1943. High altitude frostbite: preliminary report. Surg., Gynec. and Obst. 77:561-575.

14. Dolman, C. E. 1960. Type E Botulism: A hazard of the North. Arctic 13: 230-256.

15. Edwards, S. 1959. Brucella suis in the Arctic. Alaska Med. 1: 41-44.

16. Fournelle, H. J., V. Rader, and C. Allen. 1959. Seasonal study of enteric infections in Alaskan Eskimos. Pub. Health Rep. 74: 55-59.

17. Gordon, J. E., and F. L. Babbott, Jr. 1959. Acute intestinal infection in Alaska. Pub. Health Rep. 74: 49-54.

18. Gordon, J. E., and F. L. Babbott, Jr. 1959. Acute intestinal infection in the Arctic. Am. J. Pub. Health 49:1441-1453.

19. Gordon, J. E., E. A. Freundt, E. W.Brown, Jr., and F. L. Babbot, Jr. 1961. Endemic and epidemic diarrheal disease in arctic Greenland. Am. J. Med. Sci. 242: 374-390.

20. Hildes, J. A., J. C. Wilt, and W. Stackiw. 1959. Neutralizing viral antibodies in Eastern Arctic Eskimos. Can. J. Pub. Health $50: 148-151$. 
21. Hildes, J. A., J. C. Wilt, and F. J. Stanfield. 1958. Antibodies to adenovirus and psittacosis in Eastern Arctic Eskimos. Can. J. Pub. Health 49: 230-231.

22. Hollister, A. C., M. D. Beck, A. M. Gittelsohn, and E. C. Hemphill. 1955. Influence of water availability on shigella prevalence in children of farm labor families. Am. J. Pub. Health 45: $354-362$.

23. Howells, W. W. 1960. The distribution of man. Sci. Am. 203: 112-127.

24. Human Wastes in Arctic and Sub-arctic. Final Report. 1954. Army Environmental Health Laboratory of the Army Medical Service. U. S. Army Chemical Center, Maryland.

25. Huntley, B. E., J. E. Maynard, and R. N. Philip. 1962. Preliminary studies of brucellosis in Alaska. In press.

26. Lurie, M. B. 1941. Heredity, constitution and tuberculosis: an experimental study. Supplement to Am. Rev. Tuberc. Vol. 64.

27. Pauls, F. P. 1962. Chief of Laboratories - Southcentral Regional Laboratory, Anchorage, Alaska. Personal Communication.

28. Philip, R. N., B. Huntley, D. B. Lackman, and G. W. Comstock. 1962. Serologic and skin test evidence of tularemia infection among Alaska Eskimos, Indians and Aleuts. J. Infect. Dis. $110: 220-230$.

29. Philip, R. N., and D. B. Lackman. 1962. Observations on the present distribution of Influenza A/swine antibodies among Alaskan natives relative to the occurrence of influenza in 1918-1919. Am. J. Hyg. 75: 322-334.

30. Philip, R. N., K. R. Reinhard, and D. B. Lackman. 1959. Observations on a mumps epidemic in a "virgin" population. Am. J. Hyg. 69: 91-111. 


\section{BABBO'T}

31. Philip, R. N., W. T. Weeks, K. R. Reinhard, D. B. Lackman, and C. French. 1959. Observations on Asian influenza on two Alaskan islands. Pub. Health Rep. 74: 737-745.

32. Pinner, M., and J. A. Kasper. 1932. Pathological peculiarities of tuberculosis in the American Negro. Am. Rev. Tuberc. 26 : 463-491.

33. Polunin, N. 1955. Aspects of arctic botany. Am. Sci. 43: $307-322$.

34. Reinhard, K. R., and R. K. Gerloff. 1960. Immunity towards poliovirus among Alaskan natives. II. A serologic survey of 47 native communities of western and northern Alaska. Am. J. Hyg. 72: 298-307.

35. Reinhard, K. R., R. K. Gerloff, and R. N. Philip. 1960. Immunity towards poliovirus among Alaskan natives. III. A study of naturally and artificially acquired antibodies against poliovirus among residents of two Bering Sea communities. Am. J. Hyg. 72: 308-320.

36. Rausch, R. 1954. Studies on the helminth fauna of Alaska. XXIV. Echinococcus sibiricensis N. sp., from St. Lawrence Island. J. Parasitc.l. 40:659-662.

37. Schaefer, O. 1959. Medical observations and problems in the Canadian Arctic. Canad. M. A. J. 81: 248-253.

38. Schliessman, D. J., F. O. Atchley, M. J. Wilcomb, and S. F. Welch. 1958. Relation of environmental factors to the occurrence of enteric diseases in areas of eastern Kentucky. Public Health Monograph No. 54. (PHS Pub. No. 59l).

39. Schulert, A. R. 1962. Strontium-90 in Alaska. Science 136: 146-148. 
40. State of Health in Greenland, The. 1959. Annual Report from the Medical Officer in Greenland. Godthaab, Greenland. (The State of Health in Greenland).

41. Thorborg, N. B., S. Tulinius, and H. Roth. 1948. Trichinosis in Greenland. Acta Path. et Microbiol. Scand. 25: 778-794.

42. Whayne, T. F., and M. E. DeBakey. 1958. Cold Injury, Ground Type. Office of the Surgeon General, Department of the Army, Washington, D. C.

\section{DISCUSSION}

CAMPBELL: When you study these native populations, in Anakturuk Pass and Point Barrow, for example, don't you have to consider the possibility of malnutrition? It seems to me I have heard in the past that vitamins may have an influence on viruses.

BABBOTT: I think that is very important. It is a nonspecific host characteristic which I neglected to bring in, but it is important. The reason I didn't bring it in was that it has been very difficult to do detailed and sound studies on nutrition of these people, particularly in recent years when their diet has been undergoing such rapid change. Dr. Scott, of the Arctic Health Research Center, I know, has worked on certain types of anemias and on vitamin levels. I was not familiar with a very extensive literature on this, and so I did not include it; but it is important.

CAMPBELL: Aren't Eskimos calcium deficient?

BABBOTT: Not that I know of. Do you know anything about that, Dr. Reinhard?

REINHARD: Not in general, but there may be specific people 
whose diet has become so perverted that they might be calcium deficient. This matter of diet is a vexing socio-economic situation here in the northland. For instance, at Anaktuvuk Pass the diet may be highly adequate in years when the caribou are coming through en masse, and in other years, when the caribou hit another way through the mountains, the people's diet may be down to a bare minimum level.

So dietary adequacy fluctuates in these people from time to time. Now, in certain areas where the game animals numbered in the millions in the past have been depleted -- such as the Kuskoquim area -- the people just don't get as many fish, caribou, whales or seals as they did years ago. There the former diet has given way to one supplemented to a large extent by flour and sugar, which isn't especially nutritious. But it is a problem that needs study. It hasn't been studied very well, and I'm glad you brought it up. I might mention one more thing. One of the medical cliches of the past held that Eskimos were hypersusceptible to tuberculosis, but it has been demonstrated by vigorous case findings, hospitalization, and ambulent chemotherapy programs in the past eight years, that the tuberculosis epidemic could be abated rapidly, and I would like to propose that the Eskimos are considerably more resistant to tuberculosis than is generally conceded, or they might have been dead long ago -- wiped out as a race. We have to differentiate between medically underprivileged people and hypersusceptible people. They are not the same.

MITCHELL: Are we talking really and truly about tuberculosis, or are we talking about X-ray evidence of a lung infection which might be or might have been tuberculosis, or a fungus, or something other than, say, the mycobacterium?

REINHARD: We are talking about clinically proven cases of tuberculosis, the statistics of hospital admission, the decrease in positive culture results in various laboratories, the decrease in the malignancy of the cases entering hospitals, and the decrease in death rate. These are all rather positive changes that have occurred very rapidly in the last ten years. In other words, there is proof there. It is not a supposition. 
MITCHELL: The avitaminoses that you are speaking of; would you say that is something that we brought to Alaska? If we hadn't come into Alaska and depleted the food supply, the natives of this area would not be living on flour and sugar.

REINHARD: I think it would be well to get $r$ id of the concept that the white man has consistently done wrong to the Eskimo. After all, the inequities caused by interactions of colliding cultures are part of the normal history of the world, and we have to recognize that they will occur. To go back to the original question, I don't know of any real data on the general occurrence of specific avitaminoses among Alaskan natives.

NUNGESTER: Let's go back just a moment to avitaminosis. Is there any evidence of scurvy in the Eskimo?

REINHARD: I have heard that traditionally, Eskimos were supposed to have no caries, no scurvy, and no body odor.

SCHMIDT: Dr. Babbott, you mentioned that the Russian atomic tests have caused a great deal of $\mathrm{Sr}^{90}$ fallout in various parts of Alaska. I was under the impression that there were other countries also testing. Did fallout from these tests not reach Alaska?

BABBOTT: This particular study was done after the first series of Russian tests. I am sure they are not the only ones.

MITCHELL: Dr. Babbott, we could show that people in Florida are taller than the people in Alaska, maybe on the average, and perhaps attribute this to atomic detonation. When you make studies of antlers from animals here in the Arctic, do you find an increased amount of $\mathrm{Sr}^{90}$ in those antlers compared with the antlers of animals gathered, say, in California, and sent to Smithsonian prior to the detonation?

BABBOTT: I think a baseline study would be very valuable.

MITCHELL: It certainly would be indicated, because I have been plagued with information of this kind. 


\section{BABBOTT}

BLAIR: I was most interested in the observations, Dr. Reinhard, of the Eskimos' response to treatment of tuberculosis. There is so much doubt about the change in the organisms with respect to the chemotherapy, the rate of mutation of the different strains and the effect of the various agents they use. Do you have the same problem?

REINHARD: There is a paper in the 1962 AAAS Alaska Science Conference by Shepard of the $\mathrm{ADH}^{\mathrm{l}}$ laboratories which gives a resume of the decline in positive cultures over the last eight to ten years, and then in surge, in 1962. At the time she postulated that this was due to an occurrence of resisting types. However, there are many other factors that were not dealt with in the paper, or brought under control, such as the possibility that the ADH might have been going through another surge of case findings. Furthermore, the laboratory hasn't been running routine tests for resistance. So far, we don't know whether there is an increase of the resistant types. I don't know whether the Anchorage laboratory ${ }^{2}$ may have better reuslts than this. I wish we could call up Frank Pauls right now.

BERRY: We do have a man here, Dr. Huntley, from the Anchorage Laboratory. Do you have any information on this?

HUNTLEY: No, however, I know that the Alaska Department of Health Laboratory is now doing an antibiotic sensitivity study on positive TB cultures which has resulted in a tremendous increase in the number of cultures requested from field nurses. The study has not been under way long enough (probably 6 to 8 months), therefore, and no data are available on possible resistant strains.

McCLAUGHRY: I'd like to make a comment on Dr. Babbott's remark that there is no such thing as arctic medicine. This has been accepted as a concept by the National Research Council Committee on Tropical Medicines. In attempting to sharpen

1 Alaska Department of Health.

2 Laboratory, Southcentral Region, Alaska Department of Health. 
their definition of what they were concerned with in tropical medicine, they have also come to recognize the phenomenon of medical underprivilege.

ANDREWES: The thing that struck me about Dr. Babbott's paper was the very small amount of evidence there was that cold played any part in the story except indirectly. The effect of cold on the habits and crowding of the people is obviously one consequence, but you get crowding in underprivileged people all over the world, including tropical areas, with the same results. The other thing which so obviously effects the issue is the lack of past experience to particular pathogens causing these outbreaks. Now, particularly in relation to common cold research, we thought it was something of great impor tance to conduct planned studies on the behavior of isolated communities to see what happened to them when they were isolated and when they made contact with civilization again; and apparently we have missed the bus, because there don't seem to be any isolated communities, any more. Even though they have a permanent station on the South Pole, I doubt if we are ever going to be able to get the kind of information we hoped to get.

REINHARD: I don't think the cause is entirely lost. There are some semi-isolated communities right here in Alaska which would provide beautiful study opportunities to a person if he were willing to sit down in the community and test for every virus that came through, but it would be a running fight all the way. You would have to take what the Lord sent you and analyze it without a hope for control on introduction of viruses. 


\title{
THE ECOLOGY OF ENTEROVIRUSES IN ALASKA
}

\author{
Karl R. Reinhard
}

\author{
Division of Research Grants \\ National Institutes of Health \\ Bethesda 14, Maryland
}

\begin{abstract}
The paper considers the following factors; effects of various physical and chemical environments on enteroviruses, the mechanism of enteroviral infections, the carrier state in convalescent and immune individuals, and northern ethnic and social patterns. The background information on the natura! history of the enteroviruses is piecemeal. Facts may be drawn from diverse works such as the virology of water and sewage treatment, interferon and the inapparent persistence of viruses in hosts, epidemiological episudes of enterovirus infections, the effects of cold climates on community and household hygiene and sanitation, serological and cultural studies of enterovirus ecology, and morbidity and mortality statistics on northern populations. The author attempts to discern, through this piecemeal evidence, the major determinants of enterovirus ecology in northern areas.
\end{abstract}

The principal objective of this discussion will be the development of concepts about the natural history of enteroviral infections within the context of the general theme which deals with the influence of cold on host-parasite relationships. To explore adequately the relationship between arctic peoples and their environments and the enteroviruses, we must borrow from such diverse fields as virology, sanitary engineering, meteorology, anthropology, archaeology, epidemiology, and the more general aspects of natural sciences. This brief discussion does not allow an exhaustive treatment of all of these, but if some of the larger issues are clarified, the author's hopes will be fulfilled.

The large Enterovirus group is comprised of particulate agents which are commonly recoverable from the human and animal gastrointestinal tract. These viruses have a ribonucleic acid core; are about 28 millimicrons in diameter; are pathogenic for primates, suckling mice or certain types of mammalian cell tissue culture; and are stabilized by cations against thermal inactivation (Committee on Enteroviruses, 1962). In this group are the polioviruses, 
Coxsackie A and B viruses, the ECHO (Enteric Cytopathic Human Origin) viruses, the enteric viruses of animal origin, and the REO (Respiro-enteric) viruses. Why are the enteroviruses important? This is well demonstrated by the kinds of diseases they cause: poliomyelitis, encephalitis, aseptic meningitis, herpangina, pleurodynia, pericarditis, myocarditis, exanthematous fevers, gastroenteritis, and upper respiratory disease. In addition, the enteroviruses cause a variety of systemic diseases which cannot be distinguished as specific syndr omes, and which are usually diagnosed clinically as fevers of undetermined etiology (FUE). These agents are responsible for a major proportion of illnesses in children and infants, and are therefore significant in that respect alone. The enteroviruses are ubiquitous, and are frequently recovered from the upper respiratory tract or feces of people who have no overt disease. The following types of humanimmunological enteroviruses are recognized: poliovirus, three types; Coxsackie $A$, twenty-three types; Coxsackie B, six types; ECHO, twenty-six types; and REO, three types (Rosen, 1960 ; Committee on Enteroviruses, 1962). There are, in addition, a number of types of animal origin, particularly bovine and porcine strains. Of the pathogenetic and infectious characteristics, more will be related later.

All of our information on viruses emphasizes that these are obligate parasites; physiologically and metabolically incomplete organisms that must utilize other living animal or plant cells in order to persist and propagate. Undoubtedly, virologists will eventually produce non-cellular media composed of essential enzymes and metabolites for cultivating viruses. In the natural realm, however, viruses grow only in living organisms. Their existence outside of the living host is a passive one. For this reason, considerations of virus ecology are primarily considerations of host ecology plus physical environmental factors favoring passive persistence or dissemination of the virus between the propagation periods in the host. Accordingly, the effects of cold on virus ecology consist of its effects on availability and suitability of hosts for the viruses, and its effects on persistence of viruses in the physical environment outside the host.

From the epidemiological standpoint, there is little reason to believe that direct effects of cold on the human host have significant 


\section{ENTEROVIRUSES IN ALASKA}

relation to virus ecology. The arctic resident is not a hypothermic individual. Man lives successfully in the Arctic only because he maintains a subtropical micro-climate within his clothing and a temperate climate within his house. The previous speakers have emphasized the fact that the effects of cold environments are indirect; that is, they have a bearing on hygiene, sanitation, social, and individual activity patterns which affect the passage of viruses from host to host. I do not wish to minimize the message of the later discussions of effects of hypothermia on infection. These experiments are important medically from the therapeutic standpoint, and may also lead to basic information on the metabolic and physiological aspects of cellular and systemic resistance to infection; but their relation to the natural his tory of humandisease in arctic areas is difficult to discern. Exceptions to this statement may be furnished by the occasional excessive exposure of people to cold by accident or improvidence, or by the excessive exposure of the upper respiratory tract to very cold air from extreme arctic conditions or overexertion.

The cold climates operate in two, apparently paradoxical manners on the ecology of the human hosts for viruses. First of all, the aboriginal population has been forced to settle indiscrete, relatively small, often widely-separated groups, or, in the past, to live a migratory life to exploit the ecology of the basic food animals. Only in certain areas, such as the fish-rich river-valleys of the past, did boreal population groups cluster closely. The bionomics of food resources, therefore, led to isolated humancommunities, often with discontinuous communication in the colder seasons. This tended to reduce the speed of dissemination of acute infectious disease between communities. When isolation was enforced by armed guards along the trail, as is reputed to have occurred in Northwestern Alaska during the 1918-19 Influenza Pandemic, villages could escape epidemic disease. On the other hand, a cold environment causes close congested living conditions within communities and families. Consequently, a highly infectious epidemic disease spreads rapidly through a village once it is established.

These diverse effects of cold climates on human ecology and communication led to another paradox; i.e., the season in which arctic villagers were more subject to inclement weather was also the time 
when they were more free of acute infectious disease. Elder residents of St. Lawrence Island have recounted to the author how, in the "old days", from fall to spring they could expose themselves to chill and fatigue, yet never have a "cold", pneumonia, or other acute infectious disease. However, the first boat of spring arriving from the mainland would bring with it as invisible cargo acute infectious disease; particularly upper respiratory disease. Thereafter, sickness would be common on the island until freezup, when cessation of traffic from the mainland occurred. Similar experiences were common throughout the Arctic in years past. Many are the accounts of introduction of disease into arctic villages through the advent of people from areas with more concentrated population. Repeatedly, epidemic diseases such as smallpox, measles, influenza, and whooping cough decimated the population in individual villages, affecting young and old alike.

The general epidemiological patterns of the past are not generally applicable to the Arctic today; particularly not in the Western American Arctic. Most villages are in relatively close communication with urban areas because of a well-developed air transport system. There is extensive human traffic throughout the year, and now, therefore, very few villages experience the traditional freedom from acute infectious disease during the colder seasons. Recent epidemiological studies of St. Lawrence Island residents have shown the year-round occurrence of acute infectious disease (Reinhard, 1956). However, this epidemiological shift has not been recognized widely. Perhaps it has been poorly documented. Therefore, in the concepts of the large group of medical and public health professionals in the more populated southerly areas, the Arctic still is the place where people are exposed only sporadically to infectious disease and are hypersusceptible to it when it is introduced. The native arctic population is presumea to be immunologically underdeveloped.

Adherence to these obsolete concepts caused considerable alarm among those concerned with native health when a severe epidemic of poliomyelitis occurred in Anchorage and Fairbanks, Alaska in 195354. Previous severe epidemics in Greenland (Fog-Foulsen, 1955) and the eastern Canadian Arctic (Peart, 1949; Adamson, et al., 1949; Johnsen and Wood, 1954) had caused great morbidity and mortality among the native people in those areas. It was feared that similar 


\section{ENTEROVIRUSES IN ALASKA}
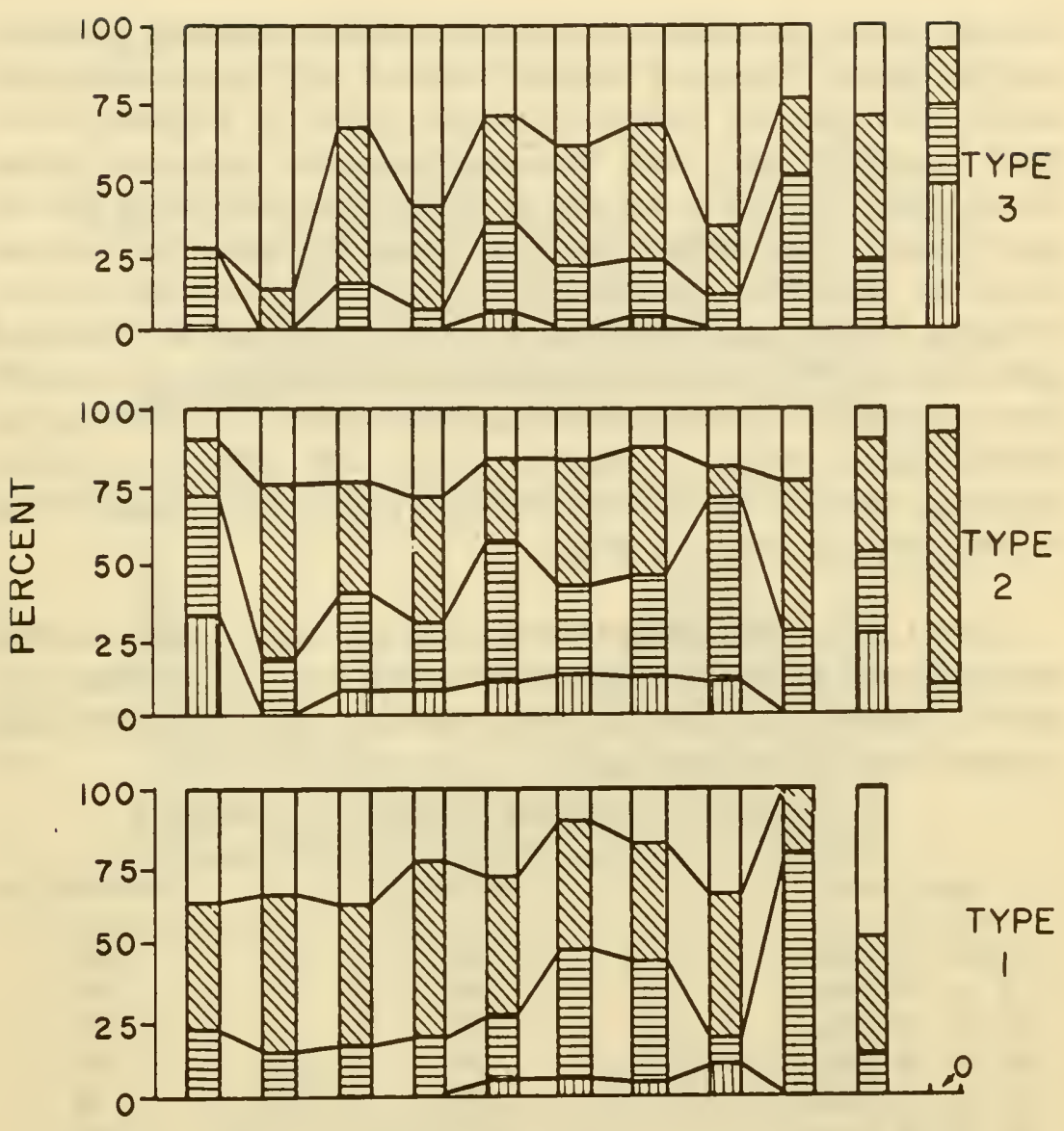

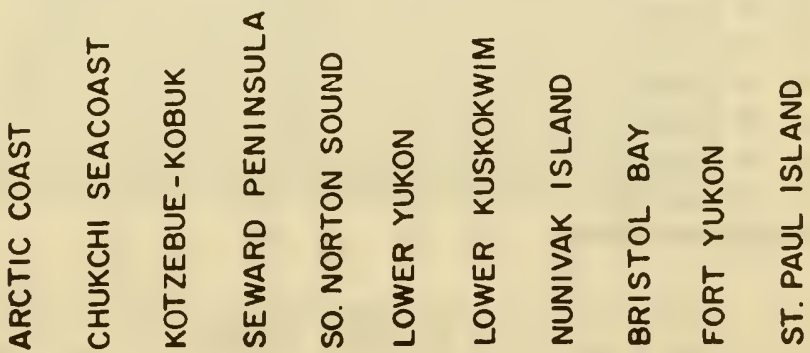

$$
\begin{aligned}
& \text { III TITER 1:512-1024 } \\
& \text { TITER 1:128-256 } \\
& \text { SS TITER 1:32-64 } \\
& \text { TITER 1:8-16 }
\end{aligned}
$$

Figure 1. The prevalence of antibodies against the three types of poliovirus in more than 700 native Alaskan males representing 47 villages in 11 geographic localities. 
disaster would be caused by extension of the Anchorage epidemic into the native villages of Alaska. However, only one satellite epidemic occurred; the unusual monotypic (Type 3) epidemic on St. Paul Island (Eklund, 1956). Sporadic cases due to various poliovirus types occurred in various native vallages, indicating that the polioviruses were active in those areas. But other than the one cited, no recognized epidemics of poliomyelitis occurred in native villages. This intriguing fact led to a series of statistical (Reinhard and Gibson, 1960) and sero-epidemiological (Reinhard and Gerloff, 1960; Reinhard, Gerloff, and Philip, 1960) studies to determine the immunological status of Alaskan natives with reference to poliomyelitis. The data are summarized by a table and two graphs from a publication currently in press.

Table I shows clearly that between 1950 and 1954, Alaskan natives experienced a much lower morbidity rate for poliomyelitis than nonnative Alaskans. The disparity was especially great in comparable groups under 15 years of age.

Morbidity Rate per 100,000 per annum

\begin{tabular}{rcc} 
Age Group & Native* & Non-Native \\
\hline Under 55 years & 29 & 208 \\
5 to 9 years & 30 & 221 \\
10 to 14 years & 38 & 228 \\
15 to 19 years & 71 & 86 \\
20 to 24 years & 25 & 66 \\
25 to 29 years & 72 & 69 \\
30 to 34 years & 72 & 61 \\
35 to 39 years & 38 & 49 \\
40 to 44 years & 29 & 35 \\
45 to 49 years & 0 & 28 \\
50 to 54 years & 0 & 13 \\
55 years and over & 0 & 0
\end{tabular}

Table I. Comparative poliomyelitis morbidity in Alaskan natives and non-natives, by five-year age groups, based on reports to the Alaska Department of Health, 1950 to 1954 . Adjusted to standard age group proportion.

Figure 1 shows graphically the prevalence of antibodies against the three types of poliovirus in more than 700 native Alaskan males representing 47 villages in 11 geographic localities. The overall prevalencies of antibodies against polioviruses were: Type I, 87 per 


\section{ENTEROVIRUSES IN ALASKA}
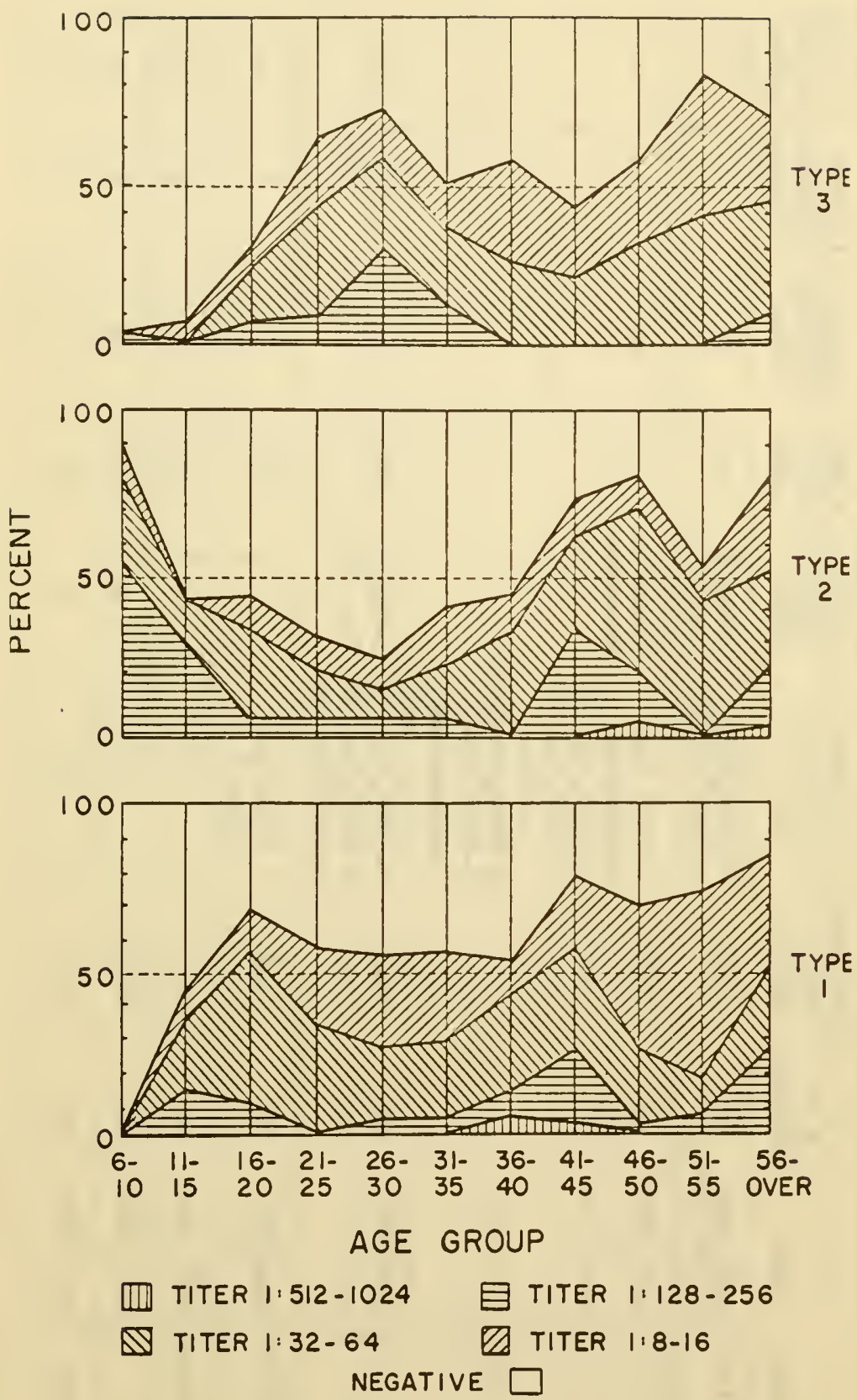

Figure 2. The results of a serological cross-sectional study of the population of St. Lawrence isl.ınc. 


\section{REINHARD}
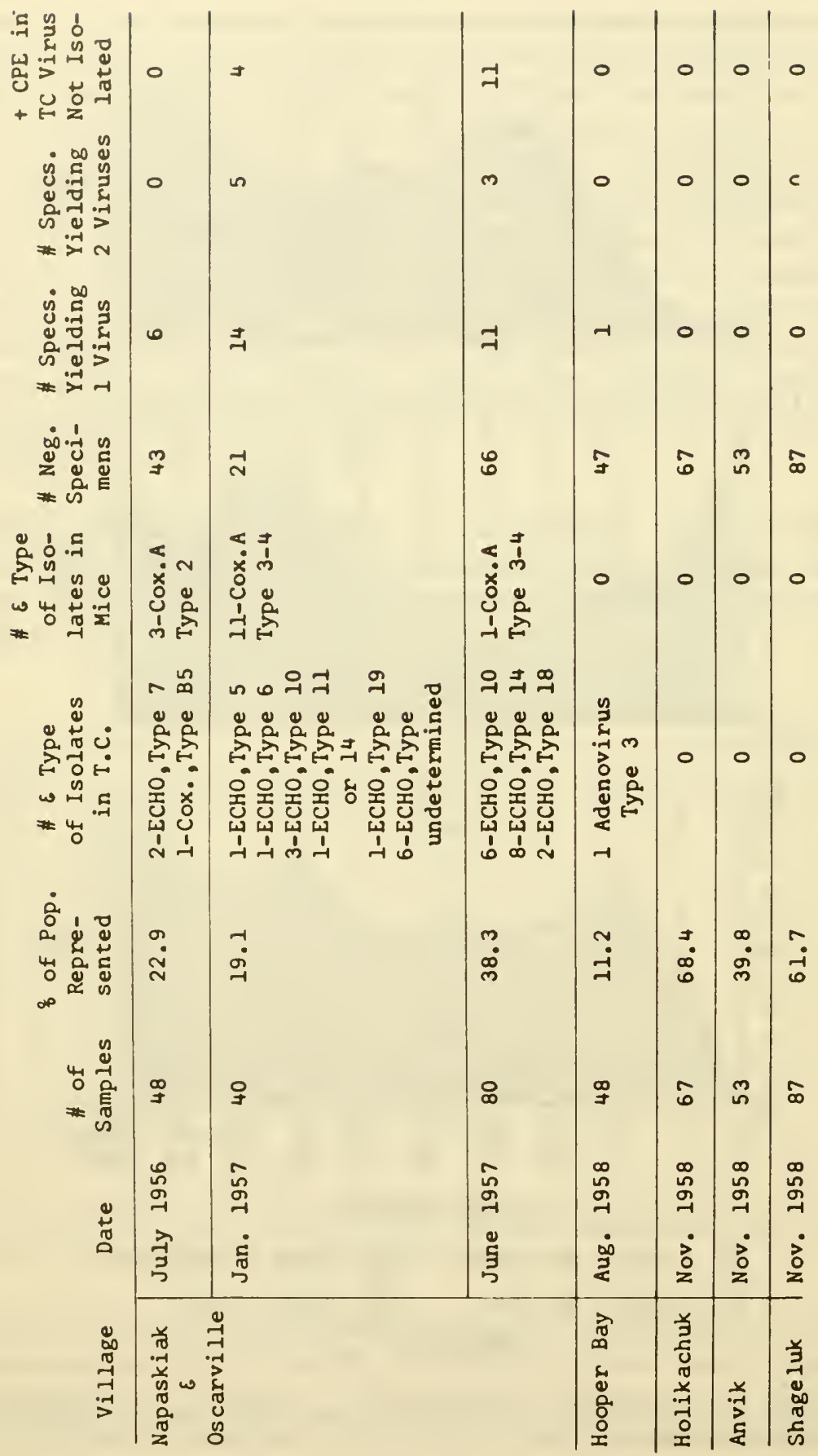

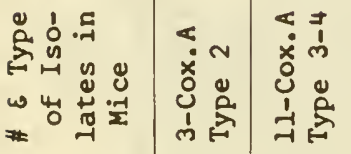

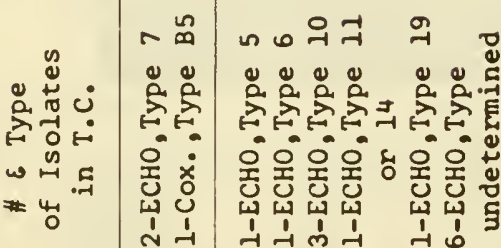

क्ष

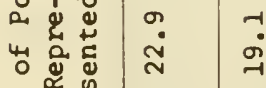

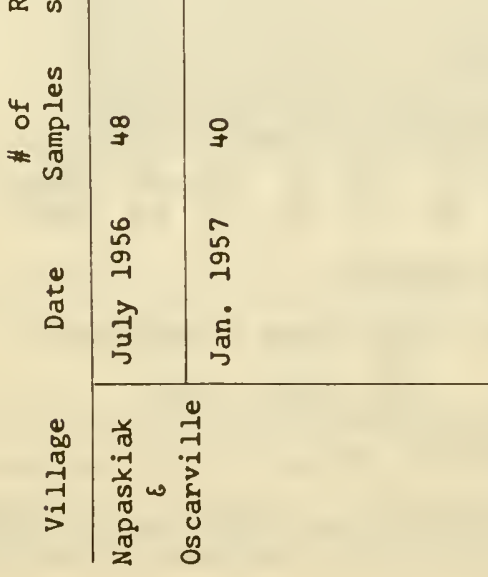


ENTEROVIRUSES IN ALASKA

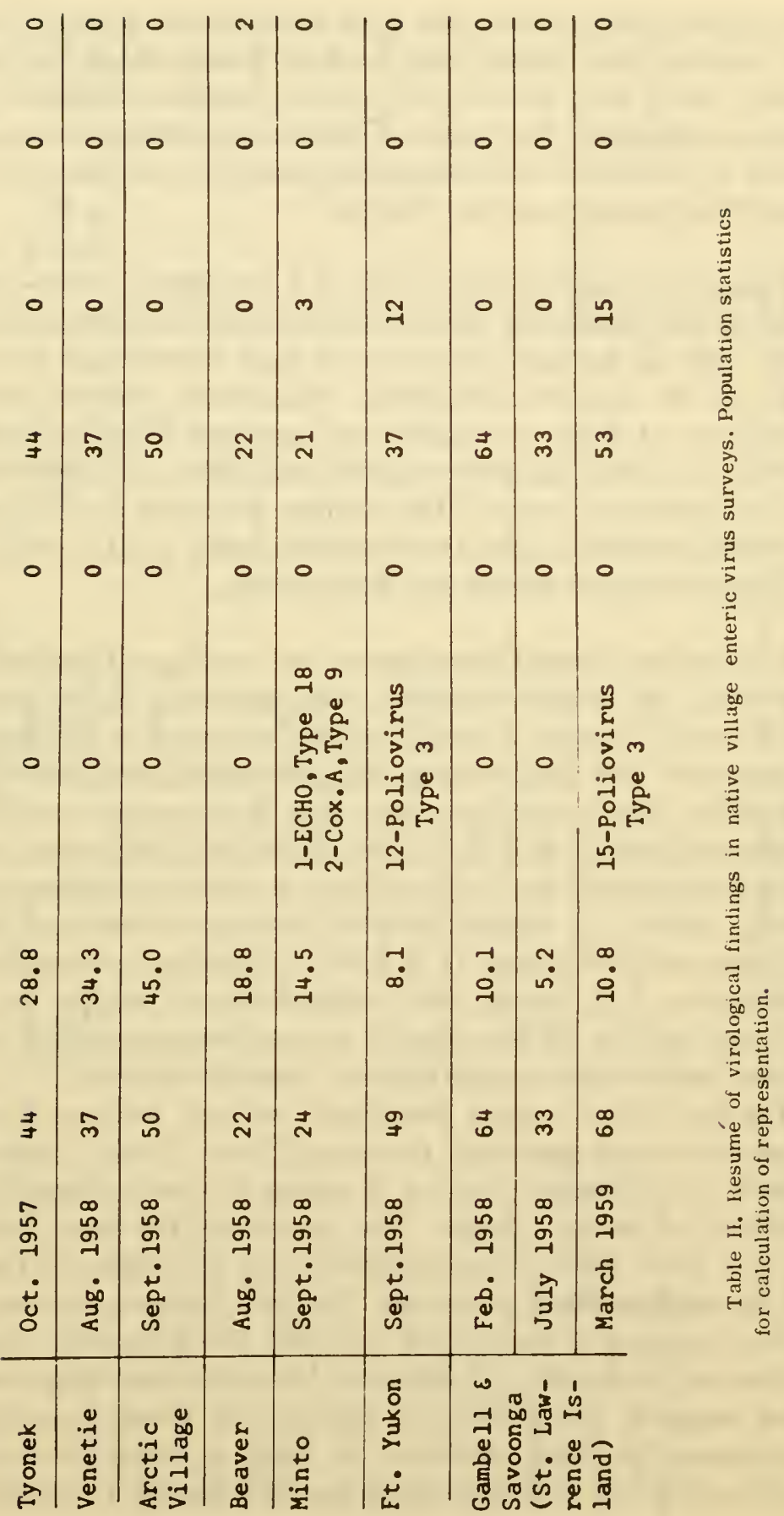


cent, Type 2, 92 per cent, and Type 3,62 per cent. Except for central Alaska (Fort Yukon) and St. Paul Island, the prevalencies of Types 1 and 2 were similar throughout. Antibodies against Type 3, which is generally the rarer of the three known poliovirus types, tended to decrease with increasing geographic latitude and consequent decreasing population density.

Figure 2 summarizes the results of a serological cross-sectional study of the population of St. Lawrence Island. Noticeable in this study were (1) the high prevalence of Type 2 antibodies in the children, (2) the apparent reciprocal relationship between decline in prevalence of Type 2 antibody and increase in Types 1 and 3, and (3) the uniformly high prevalence of antibodies to all three types in the advanced age groups. The results indicated that polioviruses have been endemic, Type 2 more sothan Types 1 and 3 , and that this situation may have existed for many years.

The epidemiological experiences and serological studies showed, therefore, that Alaskan natives were generally highly immune to polioviruses. Indeed, Alaskan natives appeared to be much more experienced with polioviruses than the urban, non-native Alaskan population. One might speculate, with good reason, that the urban Alaskan epidemics of 1953-54 and earlier years might have been derived from endemic foci in the villages. A relatively higher immunity among natives as compared with non-natives was also found by Adamson and associates in a study of a poliomyelitis epidemic in Whitehorse, Y.T. (1954). Sero-epidemiological studies by Hildes, Wilt and Stackiw (1959) indicate current development of immunity against polioviruses among eastern Canadian natives.

The poliovirus studies stiumlated cultural work on the ecology of enteroviruses generally (Reinhard, 1961). Table II presents the results of virological culture of series of stool samples from the residents of native villages. The samplings for these virological surveys were taken opportunistically, as facilitated by field work for the study of other problems. Yet these random surveys yielded a large number of enteroviral isolates. The Napaskiak-Oscarville series are particularly significant because of the large variety of types isolated, the wintertime epidemic of infection, and the long persistence of these agents in so small a population group. The samples from Ft. Yukon in September 1958 , and St. Lawrence Island 
ENTEROVIRUSES IN ALASKA

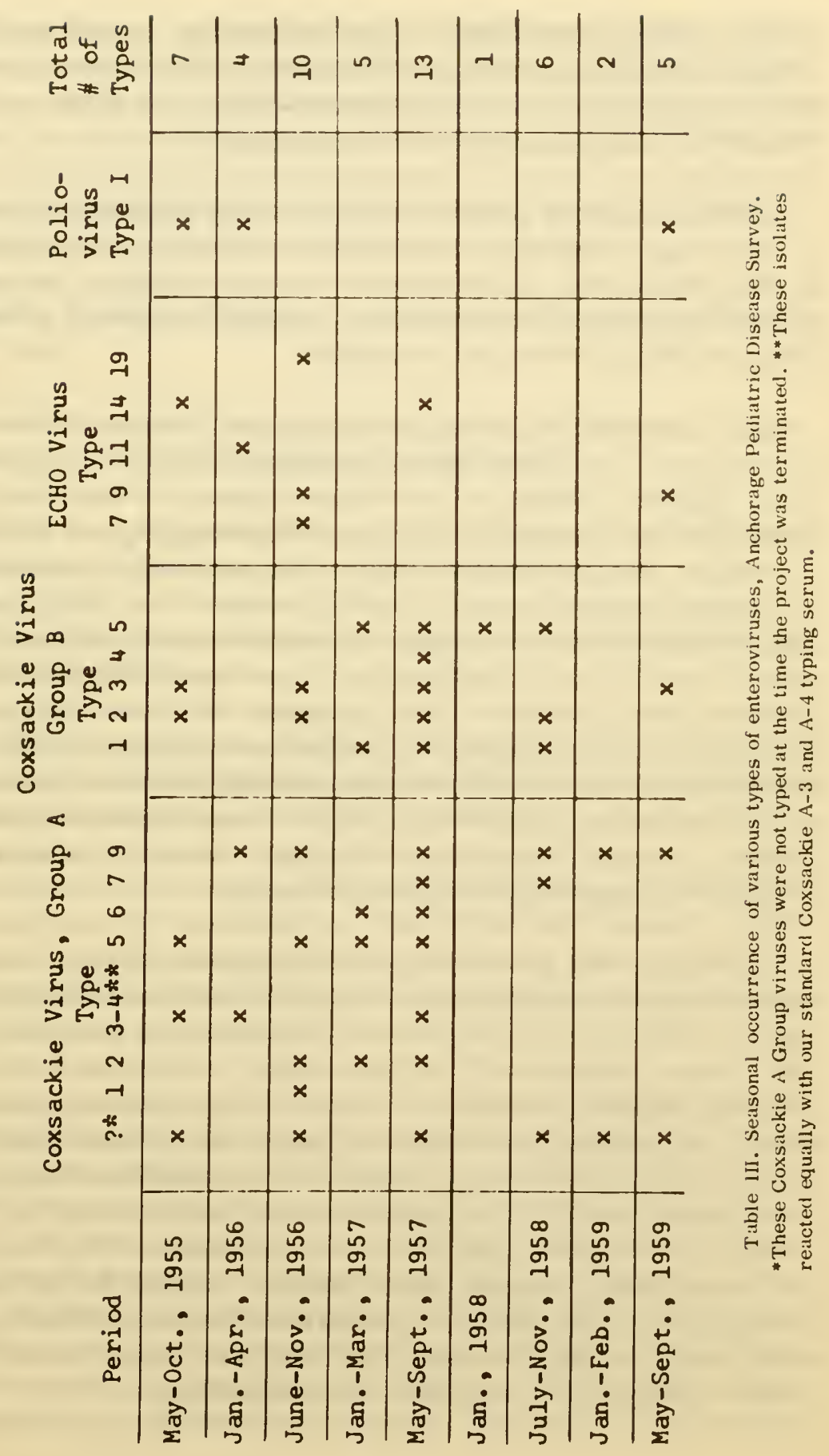


in March 1959, yielded highly significant results in that epidemic of Type 3 poliovirus infection were found to occur in individuals who had received the full course of formalin-inactivated (Salk) vaccine. None of the individuals were ill when sampled.

Table III, derived from a virological study of pediatric disease in Anchorage shows that enteroviruses were found in every season in this urban area in association with overt disease. Because of overburdened laboratory facilities, virological surveys of healthy urban residents were not conducted.

Quite unfortunately, time, facilities, and tenure of research operations did not allow these exploratory studies to mature into more rigorous studies of the natural history of enteroviral infections in the Arctic. It would have been intriguing and profitable to monitor selected representative villages closely by virological and epidemiological means in order to detect the influx, spread, and persistence of various types of enteroviruses in different geographic areas, ther eby enabling one todetermine the kind of clinical diseases which may have been associated with them. Persistence of virus in various phases of the physical environment could have been studied both naturally and experimentally. However, incomplete as the exploratory studies were, they did demonstrate that enteroviruses, in surprisingly large variety and concentration, share the arctic environment with man...or vice versa!

Confronted with the certainty of the presence and prevalence of enteroviruses in Alaska, one is liable to follow the arctic epidemiological cliché and presume that enteroviruses have been introduced into Alaska perhaps early in this century or even more recently, and have become established and entrenched in the native population before the present days of epidemiological surveillance. However, I would like to present the thesis that enteroviruses might have accompanied man in his migrations into Alaska from the Asian continent milleniums ago. Of course, this thesis is beyond proof, and it is really presented here mostly to combat the arctic epidemiological cliché. There are features of the enteroviruses, however, which suggest strongly that they have been constant companions of the human race since time immemorial. 
Parasitological philosophy has developed the concept that the more successful and probably more ancient host-parasite relationships are those in which the hostrarely becomes seriously diseased by the presence of the parasite, and the parasite is able to persist in or on the hostdespite tissue or humoral reaction. As a group, the enteroviruses qualify eminently as successful parasites. These are the general characteristics of enteroviral infections:

(l) The incidence of infection in an exposed population group is very high.

(2) Infections are frequently asymptomatic, usually benign or transitory, rarely debilitating or fatal to the host.

(3) The host frequently becomes a carrier, disseminating virus for a long period of time, particularly in the feces.

(4) Serologically immune hosts can become reinfected enterically and disseminate virus.

(5) The various types of viruses are antigenically dissimilar to the extent that heterologous immunization of the host is slight or absent, but biological interference between virus types does occur.

In addition, enteroviruses are known to be highly persistent in natural environment, particularly when mixed with organic matter stabilized by cations and in a menstruum of low biological activity such as might be caused by low ambient temperature. We shall speak of each of these points in turn.

There is ample evidence to show that enteroviruses, in general, are spread rapidly. Eklund and Larson (1959), in their study of the January 1954 epidemic of poliomyelitis on St. Paul Island, showed that the infection had pervaded the community to a major extent within 18 days. Their thorough study led them to believe that the virus may have been spread, to a large extent, from oropharyngeal secretions, either by droplets disseminated by coughing and sneezing, or by saliva exchange in the use of common utensils. Bhatt, Brooks, and Fox (1955), in their detailed viro-epidemiological surveillance of poliomyelitis infections in Louisiana, concluded that polioviruses 
spread with such facility that the household becomes the epidemiological unit; that is, if one member of a household is known to have poliovirus infection, then all members have probably become infected. Banker and Melnick (1951) firstrecovered Coxsackie viruses from North Alaskan regions, and Paul et al. (1951) found a high prevalence of antibodies against the isolate in sera from residents of the community yielding the virus. Rosen and associates (1958a; $1958 \mathrm{~b}$ ), in their detailed virological study of enteroviruses in a public child-care hospital, showed that most of the children in the institution became infected within four weeks after the natural introduction of an enterovirus. These are butfew of the many descriptions in the literature of explosive epidemics of enterovirus infection. In the Northland, the natural close association of all individuals within a small community facilitates the rapid dissemination of highly infectious agents.

Although enteroviruses are highly infectious, the likelihood that infection will result in severe disease is relatively small. In the St. Paul Epidemic cited previously, 322 Aleuts were involved and the epidemiological evidence indicated no previous experience with Type 3 poliovirus. Of these, less than 2 per cent had severe pathological involvement, and 0.9 per cent died from central paralysis. Eleven (3.4 per cent) had symptoms of benign (aseptic) meningitis, and 4.6 per cent had minor, transitory indisposition. The enterovirus ecological surveys of native villages previously cited, in which large proportions of the individuals sampled yielded virus, had no relation to epidemiological episodes of recognizable disease. The studies of child welfare institutions (Rosen et al., 1958a; 1958b) demonstrated high incidence of enterovirus infection yielded no clear picture of association of these viruses with specific disease. Some studies have shown enteroviruses other than polioviruses to be the cause of epidemics of distressing diseases such as pleurodynia and herpangina (Huebner et al., 1951; Huebner et al., 1953). The general situation, however, is that a large proportion of people who become infected with enteroviruses do not have overt symptoms of disease. This led in the early years of enterovirus discovery to the term "viruses in search of disease" or "orphan" viruses (Symposium, 1957). These clichés have now passed out of common usage, but the fact remains that enteroviruses are capable of utilizing human populations as habitation without production of a high incidence of 
ENTEROVIRUSES IN ALASKA

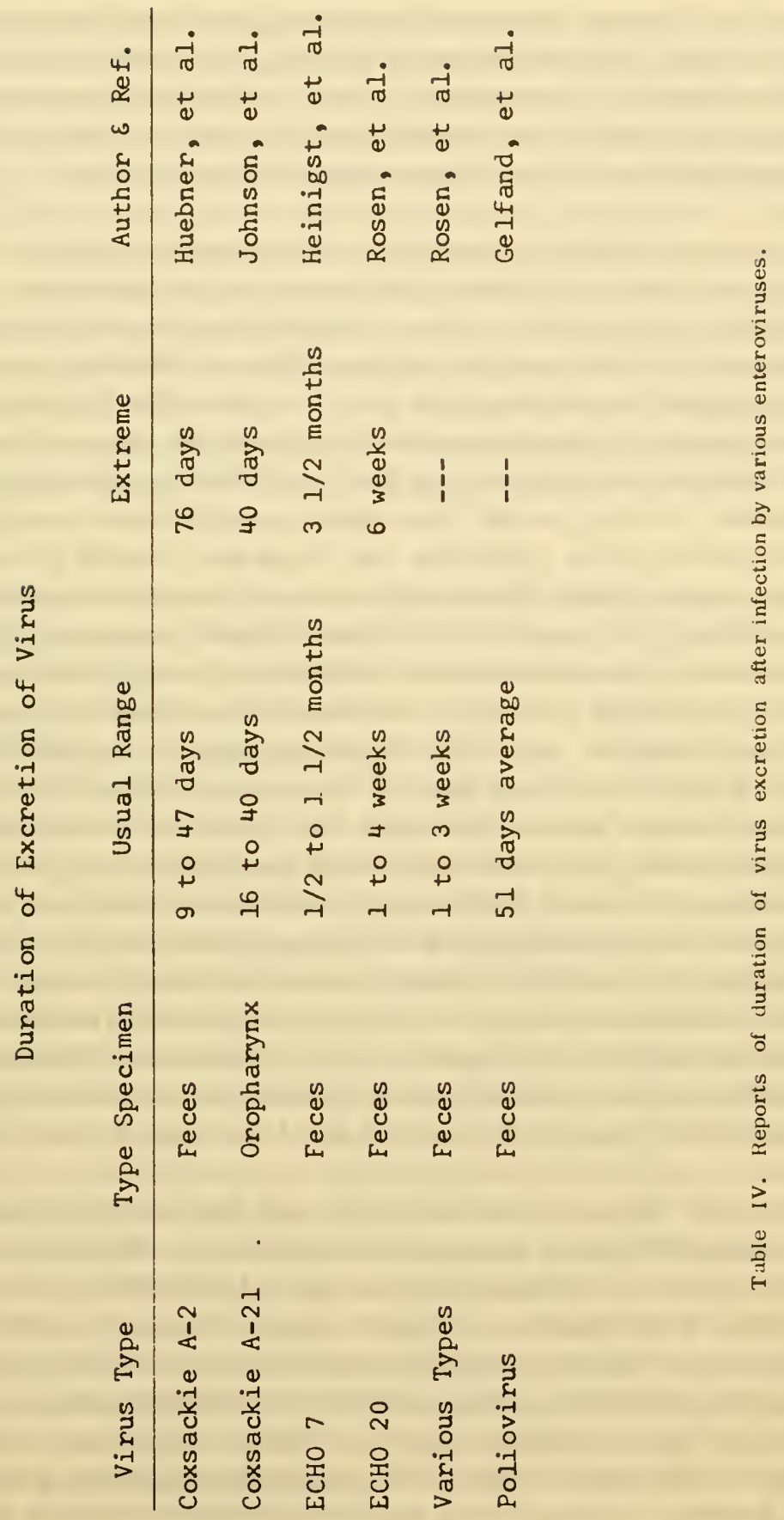


of serious disease. Even the poliovirus, the most dreaded of the enteroviruses, causes extensive pathology or death in only a very small proportion of their hosts. This fact aids in the persistence of enteroviruses; but it also makes their true bionomic status a difficult study because of the cryptic nature of their activity.

It is characteristic of enterovirus infection that the virus may be present in large quantities in oropharyngeal secretions as well as feces and intestinal secretions. Lymphoid tissue and mucosal epithelium may be the site of propagation of virus. Usually, or opharyngeal samples become negative for virus soon after the acute stage of the disease. A notable exception to this is the case of Coxsackie A-21 infection, in which virus has been found in pharnygeal swab specimens as long as 40 days after onset (Johnson et al., 1962). In most enterovirus infections the virus may be shed in feces for several weeks. Table IV shows duration of enteroviral excretion as demonstrated by a number of workers. Rather consistently, enteroviruses have been demonstrated in the feces of a significant proportion of individuals a month to six weeks after onset of enteroviral infection (Rosen et al., 1958a; 1958b; Johnson et al., 1962; Huebner et al., 1950). This means that the viruses may persist for a month in people whose serum antibodies have reached immunologically effective levels. The true duration of gastrointestinal infection is not known, for recent studies have shown that treatment of feces with freon, which dissociates antigen-antibody complex, may extend greatly the period in which virus canbe detected in the healthy or convalescent carrier (Howe, 1962). This prolonged carrier period makes the isolation of villages in cold climates less effective in the prevention of the introduction of enteroviruses, and also helps to maintain the viruses within village and local area populations.

Since the advent of the vaccines, both the formalin-inactivated and attenuated types against poliomyelitis, it has become quite apparent that circulating antibodies againstpolioviruses are no sure indication of permanent, solid immunity. Serologically-immune individuals can become reinfected with polio viruses homologous to the serum antibodies and can excrete virus (Horstmann et al., 1957; Fox et al., 1958; Gelfand etal., 1960). These reinfections are usually limited to the enteric tract and apparently are pathologically benign. However, virulent virus may be excreted for extended periods, 
leading to infection of susceptible individuals in the environment. Our own data, previously cited, on the recovery of Type 3 poliovirus from previously-immunized children in Ft. Yukon and St. Lawrence Island, comprise a modest corroboration of this infectious potential of enteroviruses. Recent work indicates that other enteroviruses may have this same infectious potential (Henigst et al., 1961). In view of the prolonged carrier state and potential for enteric infection of serologically-immune individuals, it is not surprising that enteroviruses can persist in small semi-isolated groups of arctic residents. The data graphed on Figure 2 can be interpreted to indicate that endemic poliovirus infection had persisted among the St. Lawrence Islanders for many years, despite the group's relatively small current size of 600 individuals and less in previous decades.

Although enterovirus groups may have some basic antigenic similarity (Halonen et al., 1959; Melnick, 1955; Wenner et al., 1956), they are more dissimilar in antigenic composition in that an antibody stimulated by infection with one kind of enterovirus may not protect against infection by other types (Rosen et al., 1958a; 1958b). The earliest analyses of enteroviral antigenicity were made of polioviruses. Here it was found that Type 2 poliovirus shares antigens with both Types 1 and 3 , and Type 2 antibodies may protect against infection by Types 1 and 3. But Types 1 and 3 have little antigenic similarity and antibodies against them rarely cross-protect (Hammon and Ludwig, 1957; Wilt et al., 1958; Faro, 1959). This situation is even more diversified among the large Coxsackie and ECHO virus groups. Consequently, serial infections by different enteroviruses occur. However, simultaneous, dual, or multiple infection is rare. This is due to the mechanism of non-specific biological interference mediated, according to recent discovery, by the hostproduced Interferon (Wagner, 1960; Baron and Isaacs, 1961). Thus, one virus infection may produce a transitory non-specific reaction of the host which renders the latter insusceptible for a period of time to other viral infections. These phenomena, the diversity of antigenicity and biological interference, in combination, tend to extend the period of time in which an introduced heterologous group of enteroviruses remain active in a given population group, since they limit superinfection but allow serial infection by different types. 
REINHARD

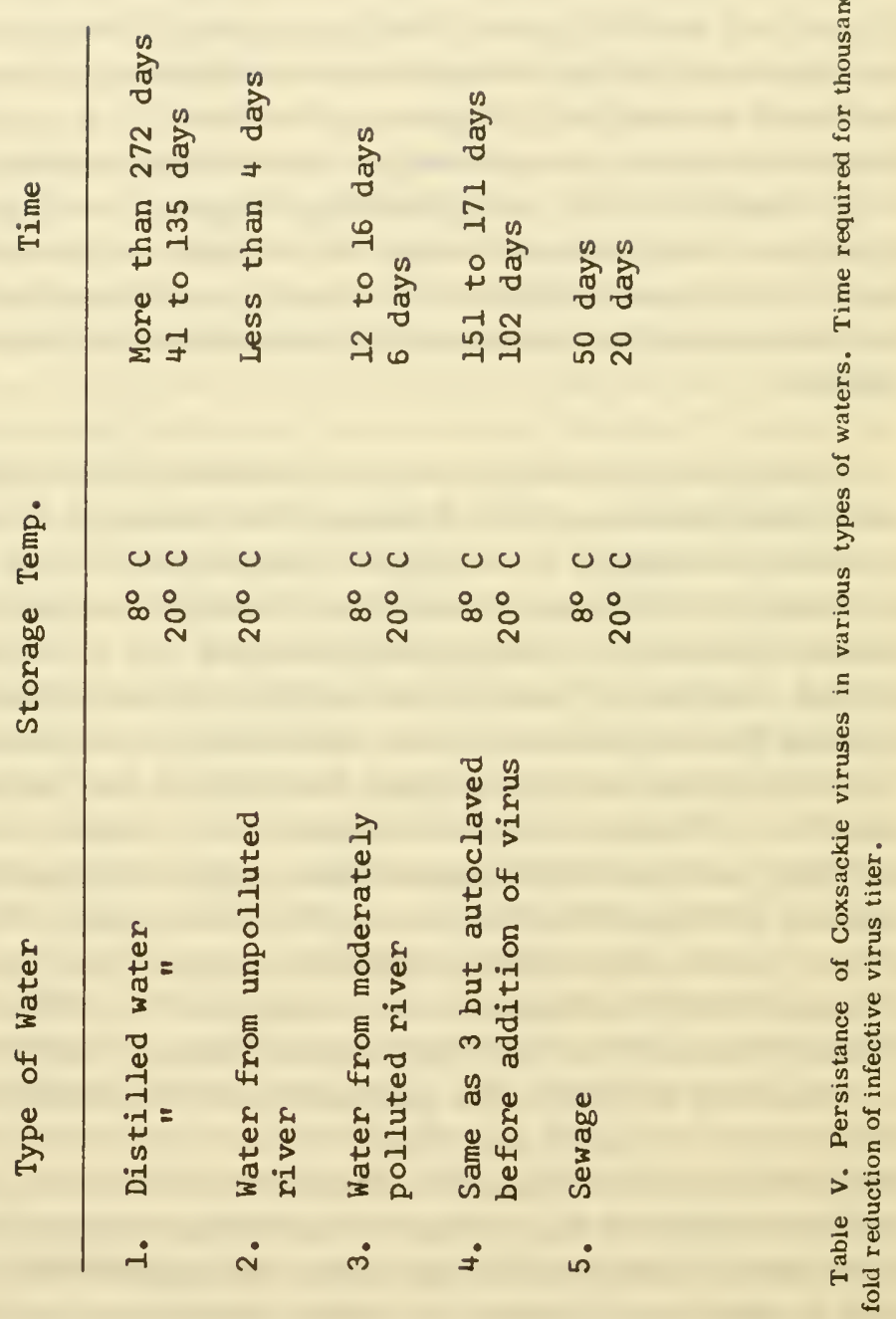




\section{ENTEROVIRUSES IN ALASKA}

Considering the foregoing facts, it is not surprising that the few exploratory studies conducted thus far have shown that enteroviruses are and have been endemic in arctic areas. However, the situation is not uniform throughout the Arctic; for example, severe poliomyelitis epidemics have occurred among natives in the eastern Canadian Arctic, in Greenland, and on St. Paul Island, yet enterovirus infections have occurred endemically and almost cryptically in most areas of the western American Arctic. The comparative isolation of communities in these diverse areas, due to differing transport and economic factors, may have much to do with the disparity of their epidemiological experience. It would be highly desirable to deter mine how long specific enteroviruses could remain endemic in single isolated villages. At present, our experimental approaches and methods may not be equal to the task. We do not understand sufficiently the role of Interferon in cryptic infection. We have inadequate information on the pathogenetic mechanism of the carrier state in convalescents and reinfection of serologicallyimmune hosts. Virological cultural methods are not adequate to recover cryptic or sparse viral flora with qualitative or quantitative reliability.

We will turn from the indirect effects of cold climates on entercviral ecology which are mediated by bionomics of the host, and consider the direct effects on the persistence of viruses in the physical environment. Salient in this respect are the studies of a number of workers who have been concerned with the presence of enteroviruses in sewage and in contaminated water supplies. Clarke and associates (1956, 1959; Taft Report) have shown that Coxsackie viruses survive long in pure waters with low biotic content and activity. In temperate waters with high biotic activity and little or no pollution, the survival of Coxsackie viruses was short. With increasing organic pollution and consequent decrease in aerobic biotic activity, the longevity of Coxsackie virus increased greatly. Chang (cited by Clarke) found that Coxsackie virus stored in 10 per cent sewage in water at $10^{\circ} \mathrm{C}$ survived for 440 days. Table $\mathrm{V}$ presents some of the data from several publications dealing with viability of enteroviruses in water and sewage, and which serve to illustrate the foregoing statements. Experimentally, low ambient temperatures were found to extend the survival of enteroviruses in natural waters and sewage. The data in Table VI, extracted from 
REINHARD

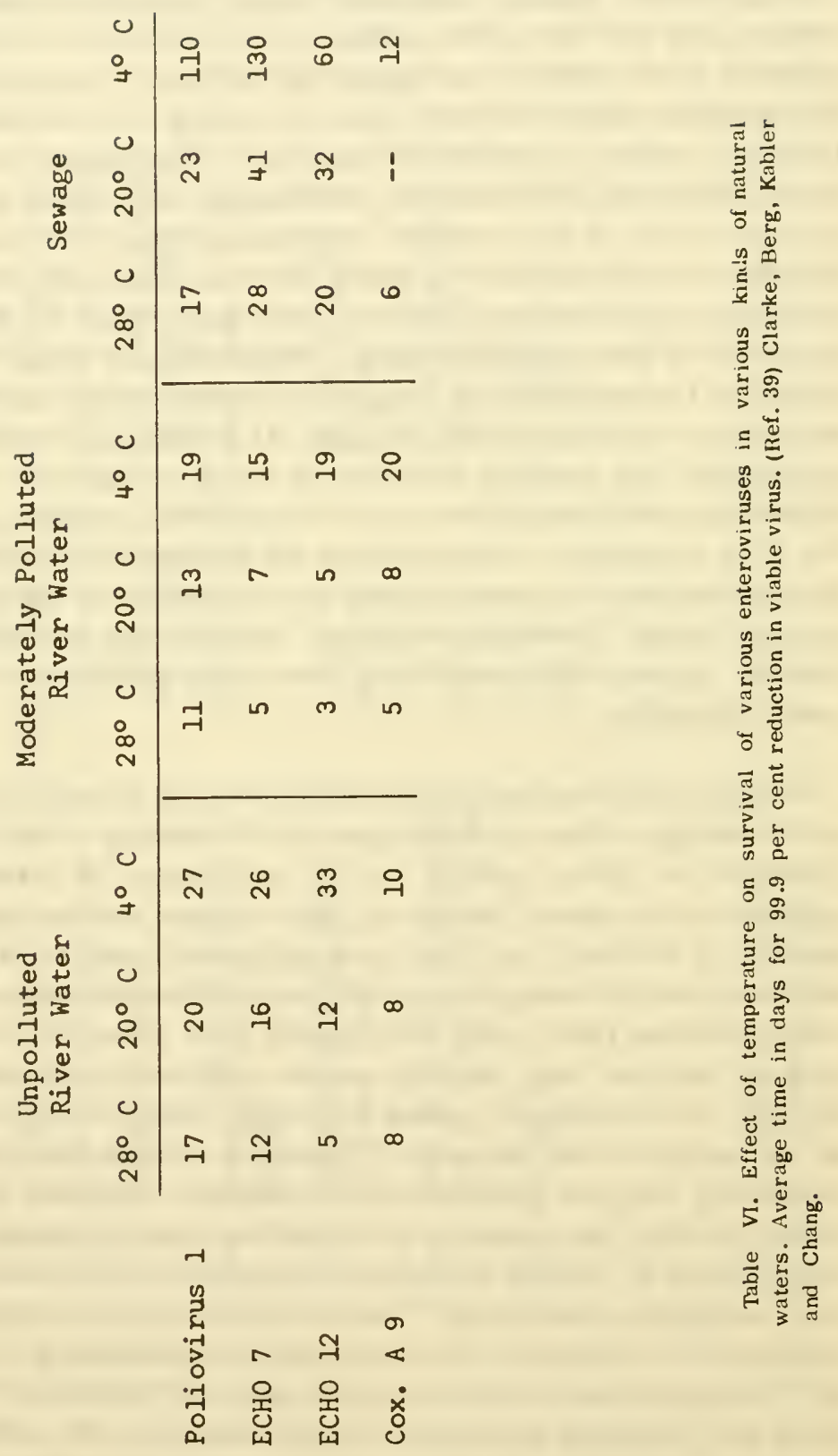


publications of the Robert A. Taft Sanitary Engineering Center, illustrate this conserving effect of low temperatures on enterovirus viability. They show that viability is enhanced further by gross organic pollution. Type 1 poliovirus and ECHO Type 7 persist two to three times longer at $4^{\circ} \mathrm{C}$ than at $28^{\circ} \mathrm{C}$ in relatively unpolluted water, but in sewage poliovirus persisted seven times and ECHO-7 four and a half times longer at the lower temperature. The preserving effect of cold storage was not nearly so marked with Coxsackie A-9 and ECHO-12 as with the first two agents.

A few laboratory studies have given some infor mation on persistence of viability of enterovirus cultures at various temperatures. In one investigation of viability of viruses in tissue culture held at $37^{\circ} \mathrm{C}$, the following half-lifes wer observed: Poliovirus- 1,47 hours ; ECHO-1, 24 hours; ECHO-4, 18 hours; ECHO- 6, 40 hours; ECHO- 9,19 hours; and ECHO- 20, 2.5 hours (Lehmann-Grube and Syverton, 1959). In another study, ECHO-20, which was quite short-lived at $37^{\circ} \mathrm{C}$, remained fully viable for a year when stored at $-20^{\circ} \mathrm{C}$ (Rosen et al., 1958a). Data kindly provided by Dr. H.G. Cramblett (1962) showed that certain enteroviruses would survive six to eleven times longer at $20^{\circ} \mathrm{C}$, and twenty to sixty times longer at $5^{\circ} \mathrm{C}$ than they did at $37^{\circ}$ C. The presence of cells and organic debris enhance viability. Although freezing is a common means of long-term preservation of viruses in laboratory procedures, little is known of a definitive naure of the effects of successive freezing and thawing. Generally, it is considered deleterious to virus viability but definitive infor mation on this point gained in controlled experiments would be desirable.

In general, the experimental evidence shows that low ambient temperatures, high organic content, and low biological activity favor the long-term persistence of enteroviruses in aquatic menstruum. These favorable conditions could be provided by the haphazard human waste disposal methods of many small arctic communities.

Limited experiments have shown that soil absorbed largequantities of poliovirus; it remained viable for three weeks in natural soil and for six weeks in previously sterilized soil (Murphy et al., 1958). These experiments were carried out at $30^{\circ} \mathrm{C}$, but one could expect much longer survival of enteroviruses in soils at lower environmental temperatures. The information available is sketchy, 
and much more extensive experiments should be conducted in which the wide variance in soil character and chemical composition are considered.

On the basis of preceding information, we can reasonable expect that the physical environment in arctic communities should be capable of maintaining viral contamination for extended periods of time. As a further complication, the low ambient temperatures of most of the seasons would tend to hinder means of eliminating pollution with viruses, for it is known that the virucidal activity of halogens is much reduced at low temperatures (Clarke and Kabler, 1954 ; Clarke et al., 1956). Clearly, enterovirus activity in arctic communities presents challenging issues to the microbiologist, epidemiologist, and sanitary engineer. Imaginative and thorough research would be required to clarify these issues.

The scope and depth of virological and immunological research in recent years have forced a revision of many a time-honored epidemiological or bionomic concept. The revisions have occasionally been drastic. In accordance with progress, it would be well to reexamine critically the current concepts of arctic epidemiology and change them to conform with the facts of natural history as they are discerned by more subtle and penetrating scientific approach and methodology. We are, however, confronted with two conditions that are conducive to investigational inadequacy. First is the relatively undeveloped condition of arctic biomedical research in that it has been accustomed to dull, often obsolescent tools, and has been carried out in piecemeal, often superficial fashion. Second is the condition of the arctic human community; it is in a state of rapid change socially, culturally, demographically, and economically. The scientific approaches must be equal to the task of discerning the forces which produce the changes as well as recording the changes quantitatively and qualitatively.

The Arctic offers fabulous opportunities for imaginative, technologically-solid epidemiological research. The unique facilities of the Arctic are the small villages with well defined, fairly stable populations. These villages can serve as convenient, easily comprehended population study groups. The semi-isolation offers excellent opportunity for the controlled study of natural introduction, 


\section{ENTEROVIRUSES IN ALASKA}

pathogenesis, persistence, and disappearance of infectious agents. The people of these villages are pleasant, cooperative and highly reliable when their individuality and dignity are respected. They prize the opportunity to participate intelligently.

In like manner, the individuality of the microbial agent must be respected. The natural history of enteroviruses is not equivalent to that of Br. abortus. Each virus group, each bacterial species, as well as each environment must be approached in a manner free of preconception in order to derive the utmost in objective information. There is no doubt that dedicated, persistent application of progressive approaches and methodology to the problems of arctic diseases will uncover a large fund of information which would not only contribute in application to the health of arctic residents, but which would also yield a greater fundamental understanding of the natural history of diseases.

\section{LITERATURE CITED}

1. Adamson, J. D., Malcolm R. Bow, and E. H. Lossing. 1954. Poliomyelitis in the Yukon. Canad. J. Pub. Health 45: 337-344.

2. Adamson, J. D., J. P. Moody, A. F. W. Peart, R. A. Smillie, J. C. Wilt, and J. W. Wood. 1949. Poliomyelitis in the Arctic. Canad. Med. Assoc. J. 61: 339-348.

3. Banker, D. D., and J. L. Melnick. 1951. Isolation of Coxsackie virus (C virus) from North Alaskan Eskimos. Am. J. Hyg. 53: 383-390.

4. Baron, S., and A. Isaacs. Interferon and natural recovery from virus diseases. New Scientist 11: 81-82. 
5. Bhatt, P. N., M. Brooks, and J. P. Fox. 1955. Extent of infection with poliomyelitis virus in household associates of clinical cases as determined serologically and by virus isolation using tissue culture methods. Am. J. Hyg. 61: 287-301.

6. Clarke, N. A., G. Berg, P. W. Kabler, and S. L. Chang. Human enteric viruses in water: source, survival and removability. Mimeo report-Robt. A. Taft. San. Eng. Ctr., USPHS, Cinn., Ohio.

7. Clarke, N. A., and S. L. Chang. 1959. Enteric viruses in water. J. Am. Water Works Assn. 51 .

8. Clarke, N. A., and P. W. Kabler.1954. The inactivation of purified Coxsackie virus in water by chlorine. Am.J. Hyg. 59: 119-127.

9. Clarke, N. A., R. E. Stevenson, and P.W. Kabler. 1956. Survival of Coxsackie virus in water and sewage. J. Am. Water Works Assn. 48.

10. Clarke, N. A., R. E. Stevenson, and P.W. Kabler. 1956. The inactivation of purified Type 3 adenovirus in water by chlorine. Am. J. Hyg. 64: 314-319.

11. Committee on Enteroviruses, National Cancer Institute, NIH.1962. Classification of human enteroviruses. Virology 16:501-504.

12. Eklund, Carl M., and Carl L. Larson. 1956. Outbreak of Type 3 poliomyelitis on St. Paul Island, Alaska. Am. J. Hyg. 63: 115-126.

13. Faro, S. N. 1959. Recurr ent paralytic poliomyelitis. New England J. Med. 260: 1177-1179.

14. Fog-Poulsen, M. 1955. Poliomyelitis in Greenland. Danish Med. Bull. (Kbh.) 2: 24l-246. 


\section{ENTEROVIRUSES IN ALASKA}

15. Fox, J. P., H. M. Gelfand, D. R. LeBlanc, and D. F. Rowan. 1958. The influence of natural and artificially induced immunity on alimentary infections with poliovirus. Am. J. Pub. Health 48: 1181-1192.

16. Gelfand, H. M., D. R. LeBlanc, J. P. Fox, and D. P. Conwell. 1957. Studies on development of natural immunity to poliomyelitis in Louisiana, part II. Am. J. Hyg. 65:367-385.

17. Gelfand, H. M., D. R. LeBlanc, Louis Potash, D. I. Clemmer, and J.P. Fox. 1960. The spread of living attenuated strains of polioviruses in two communities in southern Louisiana. J. Pub. Health $50: 767-778$.

18. Halonen, P., L. Rosen, and R. J. Huebner.1959. Homologous and heterologous complement fixing antibody in persons infected with ECHO, Coxsackie and poliomyelitis viruses. Proc. Soc. Exp. Biol. Med. 101: 236-241.

19. Hammon, W. McD., and E. H. Ludwig. 1957. Possible protective effect of previous Type 2 infection against paralytic poliomyelitis due to Type I virus. Am. J. Hyg. 66:274-280.

20. Henigst, W. W., H. M. Gelfand, D. LeBlanc, and J. P. Fox, 1961. ECHO virus Type 7 infections in a contimuously observed population group in southern Louisiana. Am. J. Trop. Med. 10: 759-766.

21. Hildes, J. A., J. C. Wilt, and W. Stackiw. 1959. Neutralizing viral antibodies in Eastern Arctic Eskimos. Canad. J. Pub. Health 50 : 148-15l.

22. Horstmann, Dorothy M., J. R. Paul, J. L. Melnick, and J. V. Deutsch. 1957. Infection induced by oral administration of attenuated poliovirus to persons possessing homotypic antibody. J. Exp. Med. 106: 159-177.

23. Howe, Howard A. 1962. Detection of poliovirus in feces of chimpanzees during late convalescence by means of frean 113. Proc. Soc. Exp. Biol. Med. 110: 110-113. 
24. Huebner, R. J., C. Armstrong, E. A. Beeman, and R. M. Cole. 1950. Studies of Coxsackie viruses. JAMA 144: 609-612.

25. Huebner, R. J., R. M. Cole, E. A. Beeman, J. A. Bell, and J. H. Peers. 1951. Herpangina-etiological studies of a specific infectious disease. JAMA 145: 628-633.

26. Huebner, R. J., J. A. Risser, J. A. Bell, E. A. Beeman, P. M. Beigelman, and J. C. Strong. 1953. Epidemic pleurodynia in Texas. New England J. Med. 248: 267-274.

27. Johnsen, H. V., and J. W. Wood.1954. An outbreak of poliomyelitis at Maguse River, N.W.T. Canad. J. Pub. Health 45: 16-17.

28. Johnson, Karl M., Henry H. Bloom, Maurice A. Mufson, and Robert M. Chanock, 1962. Acute respiratory disease associated with Coxsackie A-2l virus infection. I. Incidence in military personnel: observations in a recruit population. JAMA 179: 112-119.

29. Lehman-Grube,F., and J. T. Syverton. 1959. Thermal stability of ECHO viruses in cell culture medium. Am. J. Hyg. 69:161-165.

30. Melnick, J. L. 1955. Antigenic crossing within poliovirus types. Proc. Soc. Exp. Biol. Med. 89: 131-133.

31. Murphy, Wm. H., Jr., O. R. Eylar, E. L. Schmidt, and J. T. Syverton. 1958. Absorption and translocation of mammalian viruses by plants. Virology $6: 612-622$.

32. Paul, J. R., J. T. Riordan, and L. M. Kraft. 1951. Serological epidemiology: antibody patterns in North Alaskan Eskimos. J. Immunol. 66: 695-713.

33. Peart, A. F. W. 1949. An outbreak of poliomyelitis in Canadian Eskimos in wintertime. Canad. J. Pub. Health 40:405-417. 
34. Reinhard, Karl R. 1956. Demographic and preliminary epidemiological studies of the people of St. Lawrence Island, Alaska. Proc.Med. and Public Health Sect, 7 th Alaska Science Conference,Juneau. (Not printed in toto. Copies may be requested.)

35. Reinhard, Karl R. Notes on the ecology of enteroviruses in western arctic and subarctic regions of North America. XIII Northern Conf. on Pathol. Microbiol., Turku, Finland, and 12th Alaska Sci. Conf., 1961. To be published in JAMA.

36. Reinhard,Karl R., and R.K. Gerloff. 1960. Immunity toward poliovirus among Alaska natives.II. A serologic survey of 47 native communities of western and northern Alaska. Am.J. Hyg. 72: 298-307.

37. Reinhard, Karl R., R. K. Gerloff, and Robert N. Philip.1960. Immunity toward poliovirus among Alaska natives.III. A study of naturally and artificially acquired antibodies against poliovirus among residents of two Bering Sea communities. Am. J. Hyg. 72: $308-320$.

38. Reinhard, Karl R., and Harry V. Gibson.1960. Immunity toward poliovirus among Alaska natives. I. Comparative reported incidence of clinical poliomyelitis in Alaska natives and nonnative residents. Am. J. Hyg. 72: 289-297.

39. Rosen, Leon. 1960. Serologic grouping of reoviruses by hemagglutination-inhibition. Am. J. Hyg. 71: 242-249.

40. Rosen, Leon, James H. Johnson, Robert J. Huebner, and Joseph A. Bell. 1958a. Observations on a newly recognized ECHO virus and a description of an outbreak in a nursery.Am.J. Hyg. 67: $300-310$.

41. Rosen, Leon, Joseph A. Bell, and Robert J. Huebner. 1958b. A longitudinal study of enteroviral infections in young children. Proc. of 6th Intl.Cong. on Tropical Med. and Malaria. V: 5-13.

42. Symposium. 1957. Viruses in search of disease. Ann. N.Y. Acad. Sci. 67: 209-446. 
43. Wagner, R. R., and A. H. Levy. 1960. Biochemical aspects of microbial pathogenicity. Ann. N. Y. Acad. Sci. 88: 1021-1318.

44. Wenner, H. A., P. Kamitsuka, and M. Lenahan. 1956. A comparative study of Type II poliomyelitis viruses. II. Antigenic differences relating to 18 Type II strains. J. Immunol. $77: 220-231$.

45. Wilt, J. C., W. Stackiw, J. A. Hildes, E. Taylor, and A. J. W. Alcock. 1958. The immune status of poliomyelitis patients. Canad. Med. Assoc. J. 78: 32-34.

\section{DISCUSSION}

MARCUS: I have great fear of the Jovian wrath that falls on people who ask questions in the field of enterovirus and polio, and I have to confess, in asking this question, I am very ignorant on the whole subject. I am a little confused on a point here, though. You insinuated, I think, Dr. Reinhard, that a person who has had an enteroviral disease can recover from it and still excrete this virus as a carrier?

REINHARD: For a period of several months. We don't know actually how long.

MARCUS: This is an active infection, but it is somewhat similar in nature to what is done in immunizing with oral virus against an enterovirus. If nobody is looking, I will say it, poliovirus. I read in Readers Digest and Time that when you immunize by this means, you destroy the excretion of virus, so you don't pollute the water supply which comes from the sewage that you don't get back from the tap.

REINHARD: I wonder how well some of these concepts will stand the test of time?

MARCUS: I see. In other words, you feel that perhaps some of 
the statements that are made are not based on thoroughly tested data?

SULKIN: Not exactly. Actually, while there might be a persistence of the attenuated strain, the concept is that the very presence of the attenuated strain would prevent wild type virus from invading the host. So, you are dealing with two different agents; one interfering with the invasion of the host by the other.

REINHARD: You are speaking about biological interference?

SULKIN: Yes, this is precisely the mechanism which, it is hoped, will operate as a result of oral immunization.

MARCUS: And when the excretion of the avirulent strain ceases, you would say, then, the individual is susceptible once again?

WALKER: He is considerably more resistant to infection, even in the gut.

MARCUS: Is this true of the other enteroviruses?

WALKER: They can be reinfected with other antigenic strains, but they must be more resistant.

MITCHELL: If you had virus particles of the so-called attenuating type and the so-called wild type, equal in mumber, and you placed them before the susceptible cells, which would the cell choose? Would it choose the attemuated, or is the attenuated virus more aggressive than the wild type?

SULKIN: The point is, by introducing attenuated virus, that attemuated virus will replicate in the most desirable part of the body for that organism, which happens to be the alimentary canal, so that you no longer have equal numbers.

MITCHELL: It is already there and usually has the advantage of an increased population. A good big man can always whip a small man. 


\section{REINHARD}

SUL KIN: There are two factors to consider. One is the replication of attenuated virus, and the other is that it is conferring local immunity so that small doses of a wild type virus cannot gain a foothold in the host.

REINHARD: I'd like to propose an additional thought. You remember that in the St. Lawrence study the graphs of Types 1,2 , and 3 poliovirus antibodies indicated interference between the three types in the chronology of initial infection and immunogenesis. (See Figure 2 in manuscript.) Secondarily, there was a fifteen to twenty year periodicity between resurgence in prevalence of antibodies, correlated with increase in titers. I wish we had more extensive data to test the validity of these phenomena. I am wondering, however, whether these graphs do not give a true picture of the natural decline of antibodies in an endemically exposed population to the point where reinfection and reinforcement of antibodies takes place.

METCALF: Keeping in mind the so-called doctrine of original antigenic $\sin ^{l}$ and the experiences gained with influenza viruses, is there anything in this data which could or might be interpreted as heterological boostering of one type by another? Does that happen in the polio group?

REINHARD: Not in type-specific antibodies. Does anybody else have any information?

SULKIN: Heterotypic antibody responses have been observed in vaccinated individuals as well as following natural infection with poliovirus. Some time ago $\mathrm{Sabin}^{2}$ described the transitory appearance of Type II neutralizing antibody in patients infected with Type I poliovirus and suggested that these two types shared a common antigen.

REINHARD: This would be due to actually shared antigens. 


\section{ENTEROVIRUSES IN ALASKA}

SULKIN: Yes. In the report ${ }^{3}$ describing the immunologic classification of polioviruses into three distinct types it was indicated that they did not share a common antigen. However, other studies, such as that just referred to by Sabin, would indicate that common antigens do exist. A soluble complementfixing antigen crosses in the CF test with heterotypic poliomyelitis antibodies.

METCALF: There are serum neutralization tests. I wonder if there is any danger of a crossing here which you might miss interpreting?

REINHARD: They were remarkably specific; however, in a population cross section study like this, in the adult group, where antibodies against all three types are present, it would be difficult to unscramble the Type antibody reactions. But note, however, the early prevalence of Type 2 reactions and the later rise of Types 1 and 3 antibodies. The peak prevalence of Type 3 antibody was hinted around twenty some years of age. Type 1 was most prevalent at age twenty or so, as I remember. Of course, the peak prevelance of Type 2 antibodies was in children.

SULKIN: Isn't this quite similar to the situation reported several years ago by Hektoen and Boor ${ }^{4}$ when they studied simultaneous multiple immunization of rabbits with a variety of antigens? I recall there was a remarkable response to a blunderbuss vaccine containing as many as 35 antigens, although some "crowding out" effect was observed, that is, failure of antibody to develop to one or more antigens included in the vaccine. This may account, at least in part, for the observation to which you refer.

REINHARD: Yes.

MARROW: I should like to make one observation as a physician;

3 National Foundation Committee. 1951. Am. J. Hyg. 54: 191-204.

4 J. Infect. Dis. 48: 588-594. 1931. 
the emphasis has been upon natives as contrasted to Caucasian groups, but in a similar cultural environment in isolated geological survey parties in military and other construction groups, there is the same phenomenon. I have been clinically associated with medicine for fifteen years in this area. The fact is that when, on the rare occasion, the Caucasian lives in the same socio-economic status as the native, the pattern is very similar to that you describe.

REINHARD: Yes, right. And if you compare, say, the Alaska natives with the residents of Cairo, the situation is quite similar.

CAMPBELL: I want to bring up one question relative to the persistence of virus in relation to organic composition or the amount of organic material. I was just wondering whether this is actually a persistence or perhaps a growing; is it static or dynamic?

REINHARD: The organism is static. These were viability tests.

CAMPBELL: There is something in the high organic environment that stabilizes it.

REINHARD: Evidently. We could look back, for instance, to the protective action of colloids. In organic contamination by sewage, you probably have a few cations. Another factor, too, Dr. Campbell, is the fact that particularly in sewage, where there is an excessive amount of organic content, the aerobic biological activity is decreased. This is evidently a conditioning factor, for where there is a great amount of aerobic biologic activity, the virus just does not last very long, but when the environment becomes anaerobic or abiotic, then the virus may last a long while. For instance, in distilled water, the virus viability is greatly increased. Does that answer your question?

CAMPBELL: Not entirely, no. You really have to do an experiment, of course, and have those cells present.

REINHARD: The people at Sanitary Engineering Center were 
dealing with water in which there were actual active organisms, and they were measuring organic content, biological activity, and virus viability very closely.

WALKER: This stabilizing effect of proteins and certain ions is a fairly well known one that is used and taken advantage of regularly in the laboratory for stabilization of these and other viruses, and is used to prolong storage of viruses.

NUNGESTER: And bacteria.

REINHARD: Yes.

BERRY: Thank you, Dr. Reinhard. I suppose as moderator of this session, it is up to me to summarize everything that has been said this morning. I would not attempt it, really, but I would like to say that on the basis of this opening session, it seems rather clear that there is no evidence whatsoever of any significance that would indicate that arctic environment is particularly predisposing to human diseases of an infectious nature. There are certain unique situations that arise as a result of the environment that alter housing and in certain groups of people, the natives particularly, the diet. Their prior experience with various microbic agents, and actually these would apply not only in the Arctic, but probably in all other environments and in all other parts of the earth, shows rather clearly that in the human being, cold may or may not be stressful. In fact, the measure of man's adaptation to the arctic environment is his ability to live with minimum stress, and I assume that with minimum stress there is a minimum change and response to bacterial and viral disease. 



\title{
OPENING REMARKS ON PROBLEMS OF IMMUNIZATION IN
}

STRESSED ANIMALS

\author{
Dan H. Campbell \\ Department of Chemistry \\ California Institute of Technology \\ Pasadena, California
}

First I will orient you with our own interest which began about when Dr. Larry Irving was setting up a laboratory at Pt. Barrow. We agreed that something should be done on immunological research and biochemical problems. From this first investigation it became obvious that many problems were apparent and should be investigated.

One of the first things that interested me was the arctic ground squirrel whose body temperature goes down to near freezing when it hibernates in the winter. If it gets a little colder, the animal wakes up and shivers and then goes back to sleep. This is a rather fantastic situation, but it might be representative of the extremes between hypothermic and normal conditions. When the squirrel is active, he makes up for the time he sleeps in various ways, so that his metabolism is probably a little abnormal both in the summer and in the winter. We first began to study the blood patterns in normal and immunized animals to see if they would produce intibodies. The idea then was to go through the gamut of tests. Most of these have not yet been completed.

We studied antibody formation, and to some extent, persistence or fate of antigens and antibodies. Most of this work has never been published. One of the first interesting problems which impressed me was that in the winter time, the squirrel's blood didn't clot. At first this was a nuisance, because we wanted the blood to clot for serum studies. This was significant in that as the body temperature decreased, the clctting time increased, and in the hibernating animal, there was practically no clot formation. Back at the 
California Institute of Technolugy, Dr. irving and I continued this work using rabbits. Dr. Trapani and Dr. Sutherland joined our team there.

fit the Califcrnia Institute, we found that when we kept the rabbits at about $-20^{\circ} \mathrm{C}$, their body temperature dicin't go down, anc therefore, one couldn't call them hypothermic animals. In orier to keep rabbits alive in a "naked" state, their hair must be removed slowly. In our experiment, a strip the width of a safety razor blade was removed about every three or four days over a period of weeks until the rabbit was shaved. If the rabbit was previously conditioned to $-20^{\circ} \mathrm{C}$ for about two weeks, he would survive and live happily at $-20^{\circ} \mathrm{C}$, while an unconditioned shaved rabbit would die within 24 to 28 hours. We studied these conditicned rabbits for antibody formation, half-life of antigen, and particularly the half-life of antibodies.

While in the Arctic, we also carried out a study of blood types, including $\mathrm{Rh}$, in several Eskimo villages. Following this, some preliminary stucies were made on lemmings. They turned out to be very poor antibody formers, which indicates for the first time that the metabolic state of the animal plays a very important role in immune mechanisms. In the cold animal stored in a cold box, antibody disappeared very rapialy, which is probably due to the rapid protein turnover. In a normal rabbit, this process was about $1 / 3$ as fast.

If we put antigen in the arctic ground squirrels about the beginning of hibernation, it would be there at the enci of hibernation just before they became active, and the same thing was true with passively transferred antibody. If either antigen or antiboiy wis injected curing the summertime when they were active, it w ul. disappear very rapidly. Rabbits were etive in the cold ani their metabolism was high; under these conditions the protein turned over at a ver'y fast rate. When antibudy was injecter, it rapicily disappeared. Antigen behaves in somewhat the sume wdy, althuugh little study has been marie on this aspect as yet.

These experiments brought to mind scme survival stucies in Soncma Pass that I heard about in which there occurrei a very 


\section{IMMUNIZATION OF STRESSED ANIMALS}
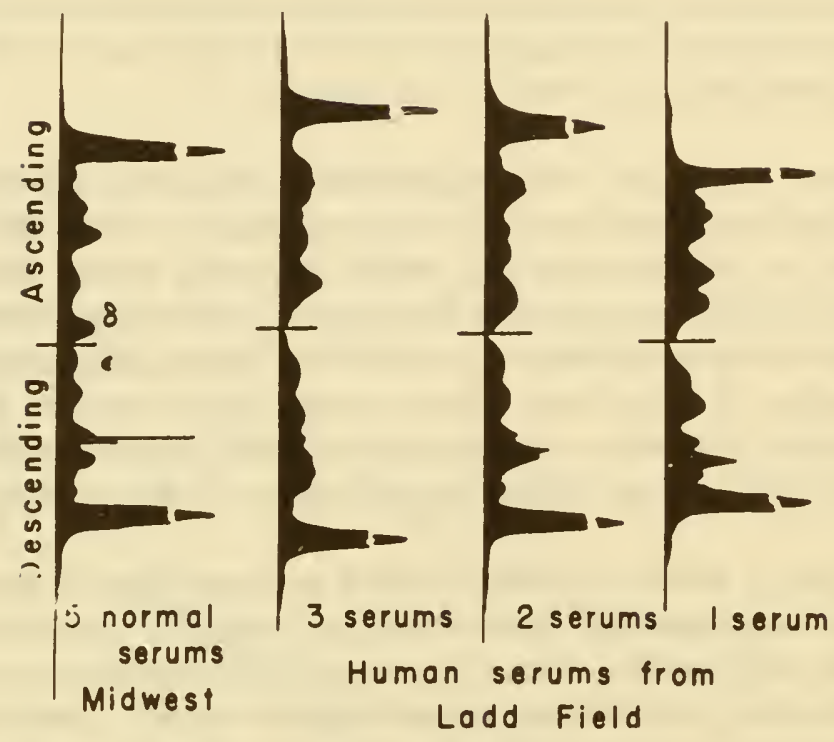

Figure 1. Electropheretic patterns of serums from active (normal) and hibernating Arctic squirrels.

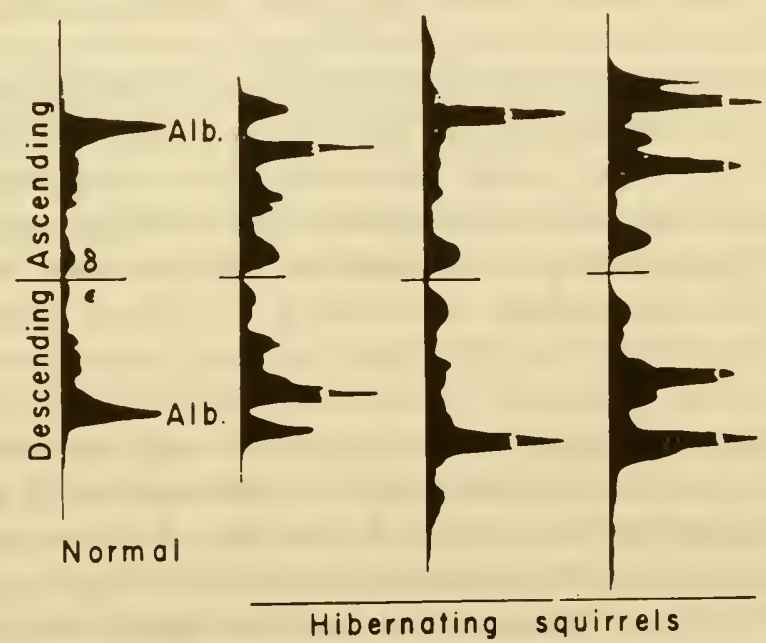

Figure 2. Electropheretic patterns of human serums obtained during late winter from Chicago area and Fairbanks area. 
high incilience of respiratory diseases among the Marines in spite of immunization. We suspect that lack of resistance was due to the rapid metabolic turnover of Ab protein.

Shown in Figure 1 is a regular electrophor etic pattern of awake and hibernating squirrels. The hibernating squirrels show a higher amount of protein than the awake squirrels which may reflect a loss of blood volume during hibernation. Note the fast-moving component which developed in a lot of the hibernating squirrels. The fibrinogen, if it is there, would probably be in the beta component. It is very difficult to interpret these data because of the extreme abnormality of the physiological state of the animal.

Figure 2 shows a comparison of serums taken in January from healthy volunteers at Ladd Field in Alaska. A peculiar thing was that the beta ancmaly, usually occurring in the descending boundary of practically all normal human serums in the temperate zones, was absent. I'm not sure that this is significant, but this beta boundary disturbance is in some way associated with lipoproteins. In the summer time most serums showed this component. In the first studies, it was concluded that serums from these men did have a higher clotting time in winter than in the summer. I never saw the actual data which should be more carefully studied.

Figure 3 presents data on the retention of antigen in the livers of normal and immunized rabbits. I have included it to show that antigen in the normal rabbit will persist for a long period of time in the liver, and can be detected up to 350 days after the last injection, thus making it a baseline. Recent work by Jerislav indicates that the antigen persists a lot longer in hibernating squirrels.

Experiments designed to determine if high altitude and low temperature had any effect on experimental asthma in guinea pigs were conducted by Dr. Heimlich and Dr. Trapani at the White Mountain laboratory. The results indicated that if guinea pigs were sensitized at room temperature and sea level, they were quite resistant to challenge. Subsequent studies suggested that this resistance was apparently a stress phenomenon, and if the guinea pigs were allowed to adapt for a few weeks, they reacted like 


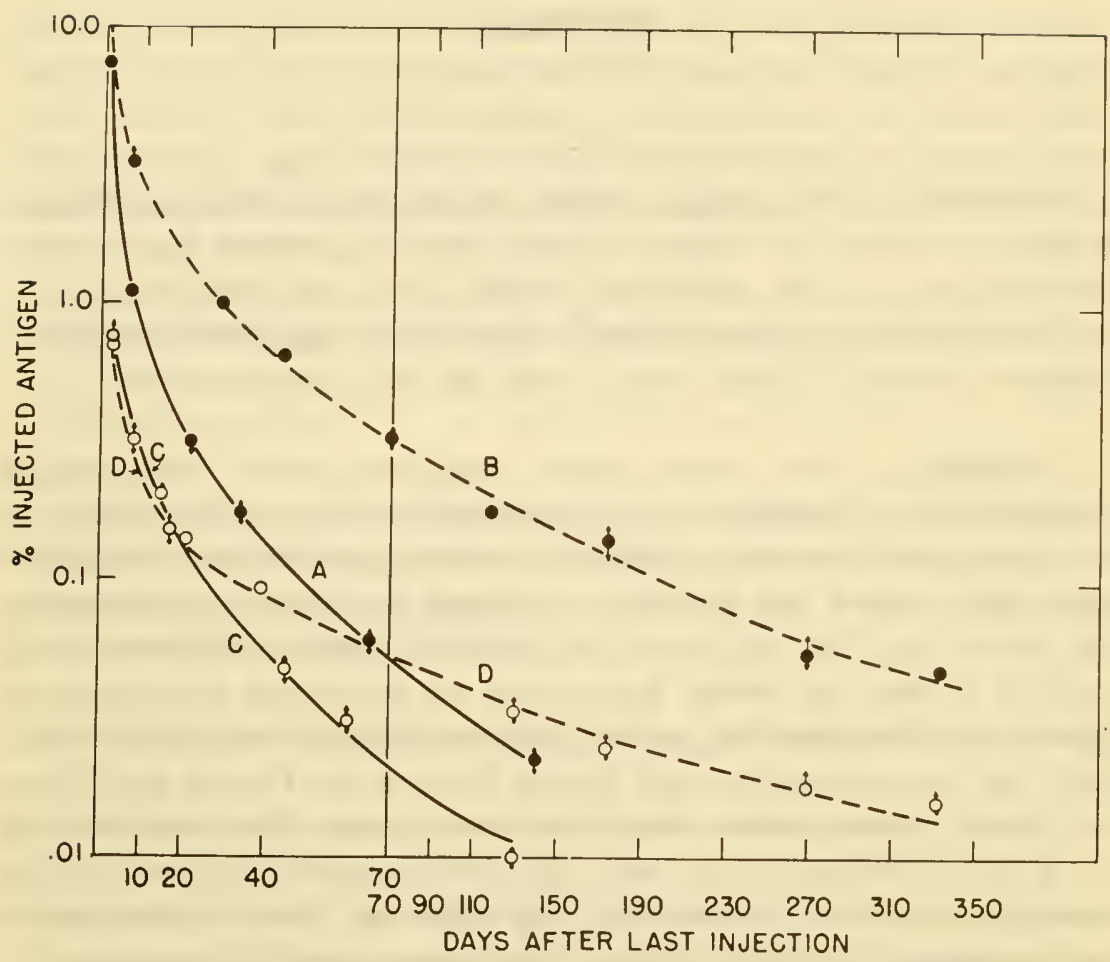

Figure 3. Semilog plot of retention in perfused liver tissue of single injection of $50 \mathrm{mg}$ of $\mathrm{S}^{35} \mathrm{BSA}$ (A); single injection of $50 \mathrm{mg} \mathrm{S}^{35} \mathrm{KLH}$ (B); 9 injections of $10 \mathrm{mg}$ each of $\mathrm{S}^{35} \mathrm{BS}$. (C); 9 injections of $10 \mathrm{mg}$ each of $\mathrm{S}^{35} \mathrm{KLH}$ (D). Each point represents average value for 3-5 rabbits. Center of circles indicates mean of distribution, indicated by the arrows. (From Garvey and Campbell, Jour. Exp. Med., 105, 361. 1957.)

animals at a higher temperature and at sea level. Apparently the answer involved hypersecretion of corticosteroids.

There are many practical problems dealing with the relation of cold stress of adaptation to immune mechanisms. Many factors other than metabolism must be involved. For example, skin tests may depend to scme extent on the state of peripheral capillary circulation, and immune responses in general willdepend upon the previous history of the subject. In finishing, I wish to emphasize the importance of Dr. Viereck's statement; namely, that the physiclogical state of an animal must be determined and not assumed. Further more, there is a great difference between stress, adaptation, and normal states. 


\section{DISCUSSION}

SULKIN: In the antigen decay experiment with the Arctic ground squirrel, I wonder if you have attempted such an experiment at a time when the animal does not ordinarily go into hibernation? In other words, have you measured antigen at another season of the year, such as the summer time?

CAMPBELL: Yes, even while they are active both antigen and antibodies disappear very rapidly in the summer time. It is a problem because squirrels do become active a while before they come out of their burrows, so actually you have to dig them out. We ciid have an artificial setup at Point Barrow, finally. It took us about two years to learn how to get them to hibernate. The first two years they all died; the next year somebody got some ambition and hauled down a few tons of sand from the Mead River where these squirrels live. The sand was put in a wire enclosure so the squirrels couldn't get out, and we could go out to the pen and dig them up. They become active for a couple of weeks before they come out of hibernation.

MONCRIEF: Does the inability to form antibody also imply an increased destruction of antigen?

CAMPBELL: I can't answer that because they go hand in hand. Now, in the production of antibody, antigen is destroyed. This is a fact. Now, whether antigen has to be destroyed, I don't know. Supposing it was not destroyed. If it is not broken down, it is not antigenic. We think that antigen is broken down into particles about the size of templates, and that antibody formation is just modified biosynthesis of gamma globulin by the RNA, because it is always associated with the soluble RNA; we know the scluble RNA does turn over during protein synthesis, and the more protein being synthesized, and the more active the cell is, the greater the rate cf this turnover. Well, when it breaks down and turns over, then this template, or some of it, may be lost. This is a reflection of the rapid protein synthesis, and some of these fragments are always being secreted 


\section{IMMUNIZATION OF STRESSED ANIMALS}

by the cell. There is a possibility, if antigen acted as a template, that it may momentarily be associated with the antibody, but actually would immediately disassociate, or disassociate soon after it got out of the cell, probably inside it. There is no question but that antigen breakdown and loss is associated with antibody formation.

MONCRIEF: Not necessarily the other way around?

CAMPBELL: No.

MONCRIEF: Do you know anything about the diet of the hibernating animal with respect to protein, carbohydrate, and fat composition that these people on Ladd Field worked with when they measured clotting time?

CAMPBELL: The hibernating animal, of course, isn't eating.

MONCRIEF: Prior to his going into hibernation.

CAMPBELL: He is in pretty good shape under natural conditions. I don't know what all they do eat, besides berries and roots, and so on.

MONCRIEF: The only reason I ask, is that a very peculiar observation came up about a year ago; Walter Blum was putting patients on starvation diets. These patients were placed on a completely carbohyürate-free siet, nothing but fat and protein; he drew blood samples from these patients and placed them in the freezing portion of the ice box, and a few weeks later when I happened to be visiting him, he took samples out to show them to me. He pulled about twenty samples of bloos out of the refrigerator, six of which were from patients on this diet. The other fourteen were frozen solid, but the six on this diet were still completely liquid. He later analyzed these for everything he could consider possible and found nothing to be abnormal in the blood except an elevation of the non-esterified fatty acids. Even serum osmolarity was the same.

CAMPBELL: I forgot to mention, these sera that don't clot, 
and even the rabbit sera that clot very poorly, are very low in complement. Complement has always been associated with clotting. I don't know just what the connection is, but the French used to consider prothrombin. Well, that turned out to be not true, but these hibernating squirrels have practically no complement, and in rabbits' sera that have been stored for a while, the complement goes down; it goes along with the blood clotting. It would be interesting to study the complement titer which might go down very rapidly in some of these patients where the blood clotting goes down after hypothermia.

BLAIR: Yes, this occurs only at fairly deep levels of hypothermia, and I think it is important to bring this out. It has been traced to reduction of platelets, and this is probably due to trapping in the capillaries. The periods of hypothermia at this level are so short that it is quite unlikely that anything happens to the fundamental mechanisms that involve the clotting. Whether there is any actual alteration in the protein response is probably unlikely for these short periods.

CAMPBELL: But even if the complement was reduced for a short period, it might play a role.

TRAPANI: Are any of these serum changes detectable before hibernation, or just following hibernation?

CAMPBELL: This is the problem, of course, and, let's see, maybe Dr. Tunevall could tell us about this work in Sweden on the polypeptide from the brown fat. I think they have been working on it in the porcupine. This is the problem that really intrigues me. The brown fat evolves during hibernation; and even the shaved rabbits will begin to show a little brown fat. This has always been associated with hibernation. If you could isolate a polypeptide, it would be the perfect anesthetic. This was realized, I think, quite a few years ago. 


\title{
ENVIRONMENTAL EXTREMES AND ENDOCRINE RELATIONSHIPS IN ANTIBODY FORMATION ${ }^{1}$
}

\author{
Ignatius L. Trapani \\ Department of Experimental Immunology \\ National Jewish Hospital \\ Denver 6, Colorado
}

\section{ABSTRACT}

This paper concerns antibody production and decay in animals exposed to environmental extremes of low temperature $\left(-15^{\circ} \mathrm{C}\right)$ or high altitude $(12,500 \mathrm{ft}$. and $14,500 \mathrm{ft}$.), or in which an imbalance in endocrine activity has been produced. It soon became apparent from our earlier studies that it was not possible to investigate the effect of environmental stress without implicating physiological alterations which might occur and thus influence the synthesis and metabolism of antibody. Our studies were extended to include animals which were in endocrine imbalance in an attempt to isolate 'one of several physiological factors which might be altered under conditions of stress. The study of these physiological factors, their inter-relationships, and their influence on antibody synthesis and decay is expressed in the term immunophysiology. The study of adrenalectomized, thyroxin-treated, and surgically thyroidectomized animals helps to explain the immune response of cold-exposed animals which exhibit an Increased thyroid activity. The immune response can be thought of as being composed of two processes; antibody production and antibody decay, occuring simultaneously, but not necessarily at the same rate. For example, a net increase in circulating antibody might arise from (a) an unchanged production associated with a decreased rate of decay; (b) an increased production associated with a decreased rate of decay; or (c) a decreased production associated with a marked decrease in decay rate.

The discussion I wish to present concerns antibody production and decay in animals exposed to environmental extremes of low temperature $\left(-15^{\circ} \mathrm{C}\right)$ or high altitude $(12,500 \mathrm{ft}$. and $14,150 \mathrm{ft}$. $)$, or in which an imbalance in endocrine activity has been produced (Trapani, 1957, 1960, 1961; Trapani and Campbell, 1959; Trapani, Lein, and Campbell, 1959a and 1959b; Trapani and Jordan, 1962).

1 These studies were aided by Contract Nonr $3545(00)$ (NR 102-573) between the Office of Naval Research, Department of the Navy, and the National Jewish Hospital at Denver. 
The experimental animal was the rabbit; the antigen-antibody system used was bovine serum albumin (BSA) and anti-BSA precipitins. The low temperature studies were done in an especially constructed cold box having a capacity of 10 rabbits. Adequa te provision was made for lighting and fresh air without drafts, and the animals were kept on wire mesh in individual cages. Water was changed four times a day because of freezing and standard food was provided ad libitum. Animals exposed to high altitude were maintained at the Barcroft Laboratory (altitude $=12,500 \mathrm{ft}$.) of the White Mountain High Altitude Station in California, or, in more recent studies, at the Summit Laboratory (altitude $=14,150 \mathrm{ft}$.) of the InterUniversity High Altitude Labor atory, Mount Evans, Colorado.

Much of the work discussed here was done in collaboration with Professor Dan H. Campbell at the California Institute of Technology.

It became apparent from our earlier studies on the immune response that it was not possible to investigate the effect of environmental stress without implicating physiological alterations which might occur and thus influence the synthesis and metabolism of antibody. Our initial studies on the effect of low environmental temperature and high altitude were extended to include experiments on animals which were in endocrine imbalance in an attempt to isolate one of several physiological factors which might be altered under conditions of stress. The study of these physiological factors, their inter-relationships, and their influence on antibody synthesis and decay is expressed in the term immunophysiology.

The purpose of my discussion is not necessarily oriented toward the elucidation of all of the problems relating to antibody formation, but rather to emphasize some of its complexities and some of the secondary factors which influence the immune response. The topic of interest, for the moment, is not concerned with speculations relating to cellular mechanisms per se which maybe responsible for, or may participate in, the synthesis of a particular protein by antibody forming cells. Rather, I will attempt to elucidate the role of certain physiological factors which influence the basic synthetic mechanisms involved in our test system.

Buried in the literature of the exploits of people exposed, either 
by design or accident, to environmental extremes of low temperature or high altitude are accounts of changes in resistance to infection and disease. However, little quantitative experimental work on the immune response has been done under controlled environmental conditions. Some of our first studies were those utilizing rabbits acclimatized to an environmental temperature of $-15^{\circ} \mathrm{C}$, or else exposed to an altitude of $12,500 \mathrm{ft}$. at the Barcroft Laboratory of the White Mountain High Altitude Station in California.

A first approach to the investigation of the immune response was the study of protein turnover, by passive immunization techniques. In this procedure, homologous gamma globulin containing specific antibody is injected intravenously into recipient animals. The animals are bled periodically, and the concentration of serum antibody estimated by quantitative micro-precipitin analysis (Lanni, Dillon, and Beard, 1950). The results are plotted semi-logarithmically as the percentage of the injected dose remaining in the circulation versus time. The slope of the linear portion of the curve (assumed to be steady state loss of antibody) is calculated by the method of least squares, extrapolated back to zero time, and the half-life of the injected antibody calculated from that point.

The half-life of passively administered homologous antibody for controls, cold-exposed, and high-altitude adapted animals was: $4.7 \pm 0.2,3.4 \pm 0.2$, and $4.5 \pm 0.2$ days, respectively. The cold exposed animals have a significantly increased rate of antibody turnover, while those at high altitude do not.

Rabbits exposed to $-15^{\circ} \mathrm{C}$ for 10 weeks and clipped of hair during the latter half of that period were actively immunized by the subcutaneous injection of BSA (10 mg per $\mathrm{kg}$ body weight) in Freund's adjuvant. Levels of circulating antibody were followed for a period of 52 weeks (Fig. 1). Rabbits maintained at room temperature and treated in the same manner were used as controls.

The level of circulating antibody in the cold exposed group increased at a slower rate than in the control group and approached control levels at approximately 14 weeks. There was then a decline in both groups, but at different rates, throughout the remainder of the experimental period, so that by the end of 52 weeks the level 


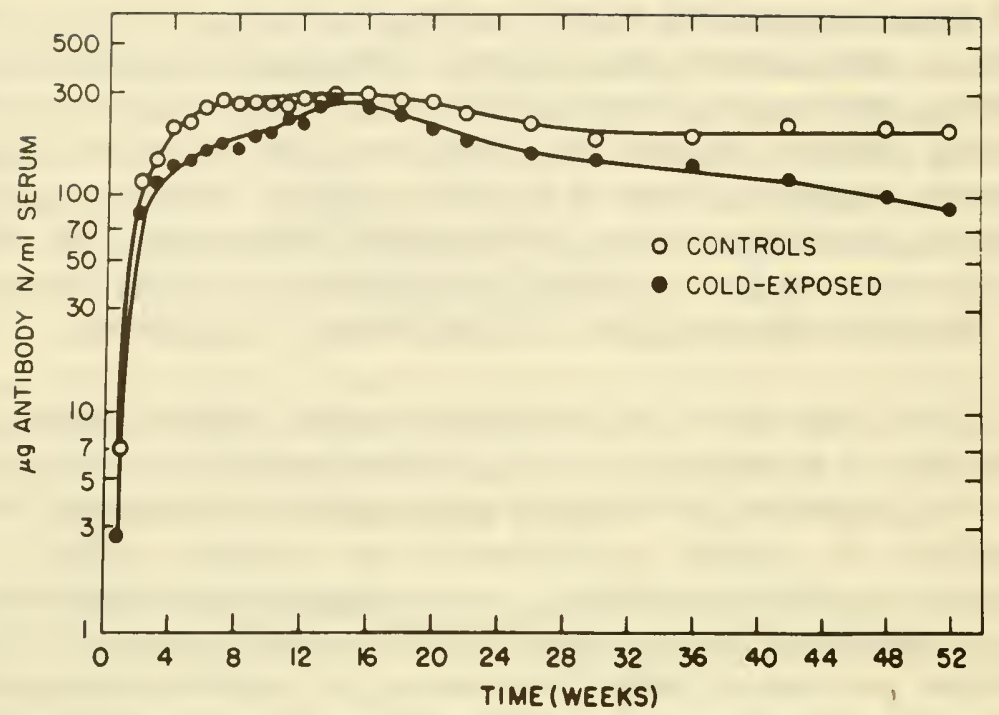

Figure 1. Circulating antibody levels in rabbits immunized with BSA plus Freund's adjuvent ( $10 \mathrm{mg}$ BSA per $\mathrm{kg}$ body wt) at time zero. The cold exposed group, kept at an environmental temperature of $-15^{\circ} \mathrm{C}$, was progressively clipped during the first 8 weeks and immunized after a 10 -week exposure.

of circulating antibody in the cold exposed group was approximately 50 per cent of that in the control group.

If these data alone are considered, it would appear that the cold exposed animal does not synthesize antibody as well as the nonexposed animal. However, it must be remembered that curves of this type represent not only antibody production, but also antibody decay. Thus, part of the difference maybe attributed to an increase in protein degradation, as inferred from passive antibody decay studies.

Since cold exposed animals have been shown to have increased thyroid activity, it seemed important to investigate the activity of the thyroid gland on the immune response. Studies were based on the a priori assumption that hyperactivity of the thyroid contributed to the immune response of cold exposed animals. The interesting and complicating fact is that eventhough the assumption may be valid, the experimental observations did not answer completely our questions. 


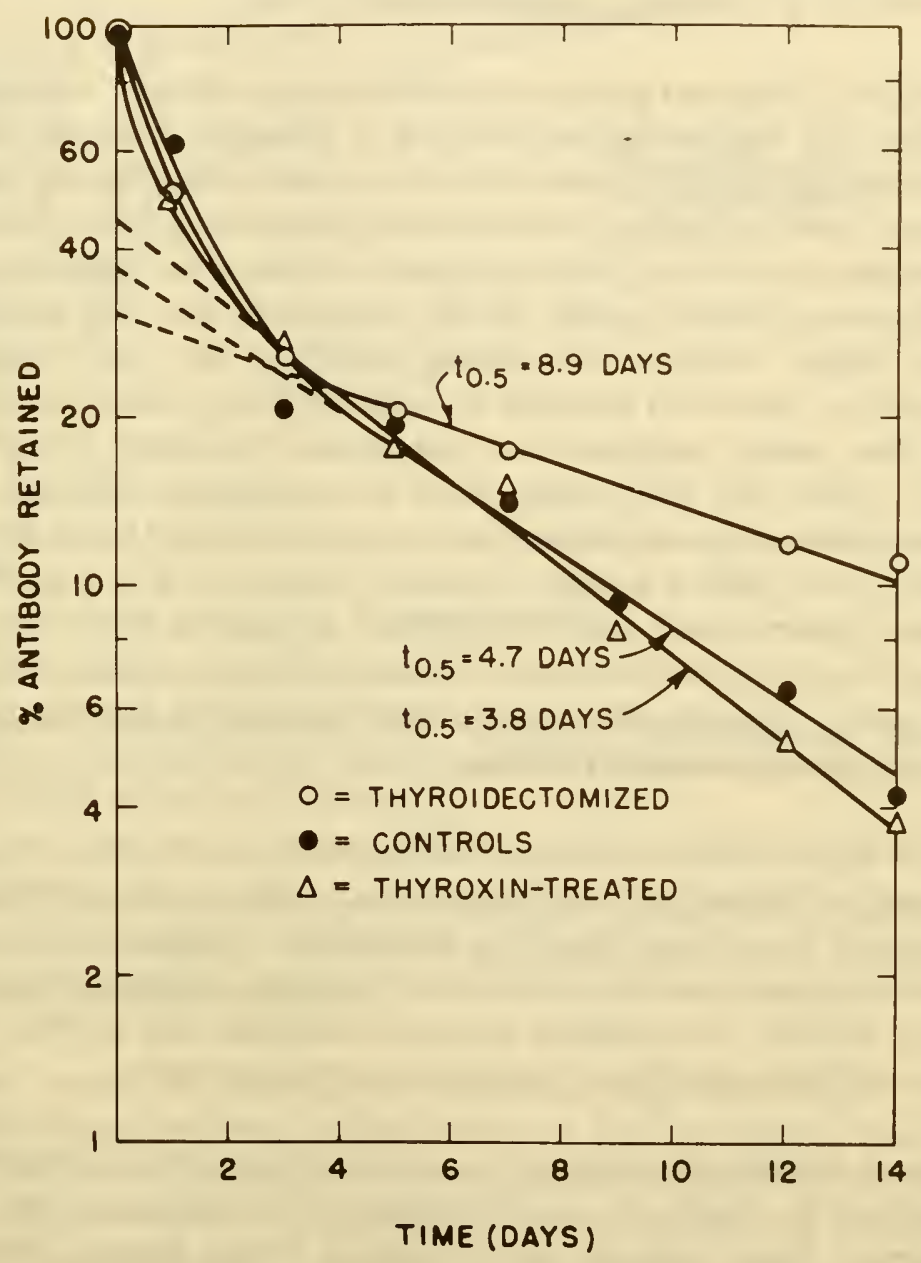

Figure 2. Passive antibudy decay in surgically thyroidectomized, thyroxin-treated and untreated control rabbits. 
A study was made of passive and active immunization in rabbits which were either surgically thyroidectomized or treated with thyroxin. The half-life of passively administered antibody in thyroidectomized, thyroxin-treated, and controls (Fig. 2) was: $8.9 \star 0.4,3.8 \pm$ 0.2 , and $4.7 \pm 0.2$ days, respectively.

Similarly prepared groups of rabbits were actively immunized with BSA (10 $\mathrm{mg}$ per $\mathrm{kg}$ body weight) in Freund's adjuvant. Figure 3 displays the data obtained from the experiment. The circulating antibody level in the thyroidectomized group rises gradually and approximates the control level at about 14 weeks after immunization. The thyroxin-treated group, on the other hand, not only had an initially higher level of circulating antibody, but also displayed measurably increased amounts of antibody 3 days after immunization. This early response was not present in either of the other groups. After the initial high level of circulating antibody in the thyroxin-treated group, there was a decline tolevels below those of controls, and then a second increase. Thus, there is a similarity between hyperthyroid and cold exposed animals in terms of an increased rate of proteinturnover. However, the net immune response after active immunization shows little similarity between hyperthyroid and cold exposed rabbits.

Since experiments concerned with thyroid activity did not clarify the results obtained with cold exposed animals, we next investigated the role of the adrenal gland on the immune response. One reason for this approach was the observation thathigh-altitude acclimatized rabbits showed an increased immune response, and animals under these conditions exhibit an increased adrenal activity.

Figure 4 shows the results of active immunization of rabbits acclimatized to $14,150 \mathrm{ft}$. at the Summit Laboratory of the InterUniversity High Altitude Laboratory at Mount Evans, Colorado. Immunization was accomplished with a single intravenous injection of $10 \mathrm{mg}$ BSA per $\mathrm{kg}$ body weight. The animals were bled periodically for the next 5 weeks and then returned to Denver (altitude $=$ $5,280 \mathrm{ft}$.) where further samples were taken. After circulating antibody had reached low levels, the animals were given a secondary intravenous challenge with $10 \mathrm{mg}$ BSA per $\mathrm{kg}$ body weight. Sixteen weeks later, a third immunization dose was given in the same 


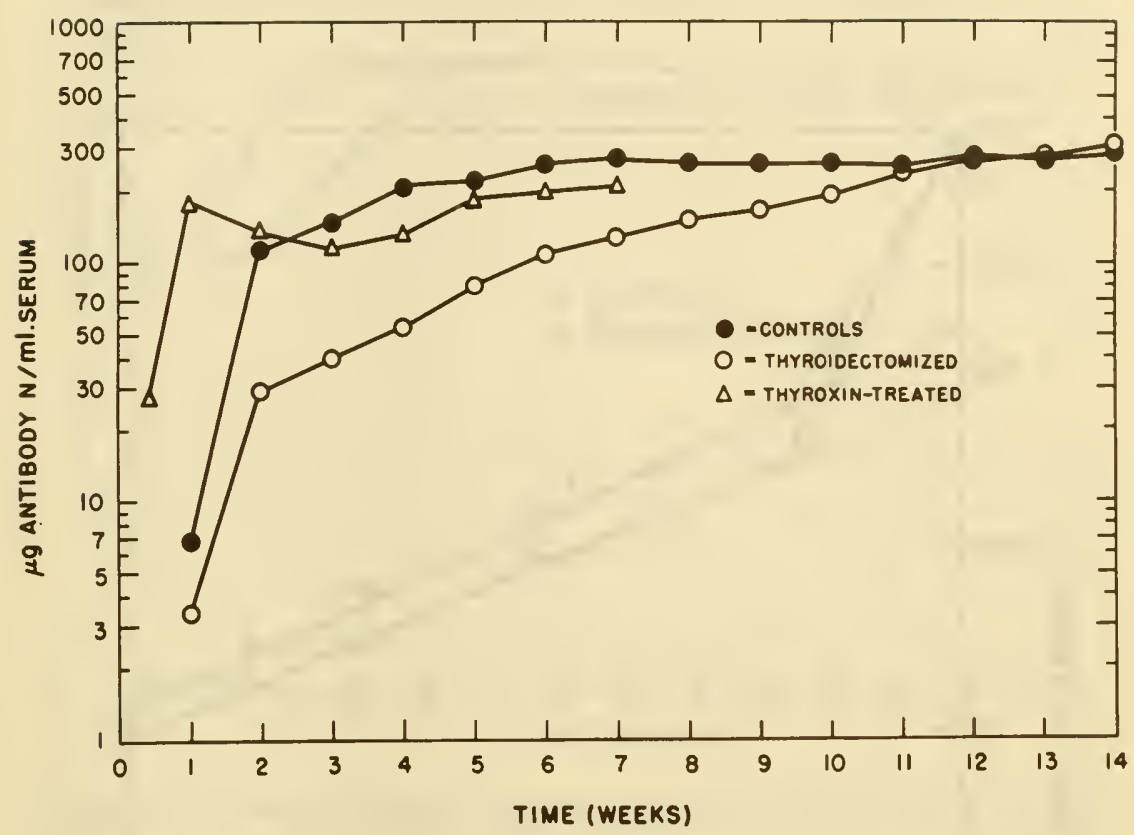

Figure 3. Circulating antibody levels in surgically thyroidectomized, thyroxintreated, and untreated control rabbits immunized with BSA plus Freund's adjuvant (10 mg BSA per $\mathrm{kg}$ body $w t$ ) at time zero.

manner. Maximum utilization of the experiment could be had in this way, and information relative to the time course of re-adaption to the lower altitude obtained.

After primary injection, the animals at high altitude had levels of circulating antibody approximately 60 per cent higher than controls, and were significantly different. After the secondary challenge, the group previously exposed to high altitude had levels of circulating antibody approximately 35 per cent higher than controls, even though they had been residing at the lower altitude for about six weeks. A third immunization, 22 weeks after descent to lower altitude, showed no difference between the two groups. In this experiment, the time course of response to the antigenic stimulus was similar for both groups. The maximums reached, however, by the high-altitude group were greater both while at the mountain and 6 weeks after returning to the lower altitude. 
TRAPANI

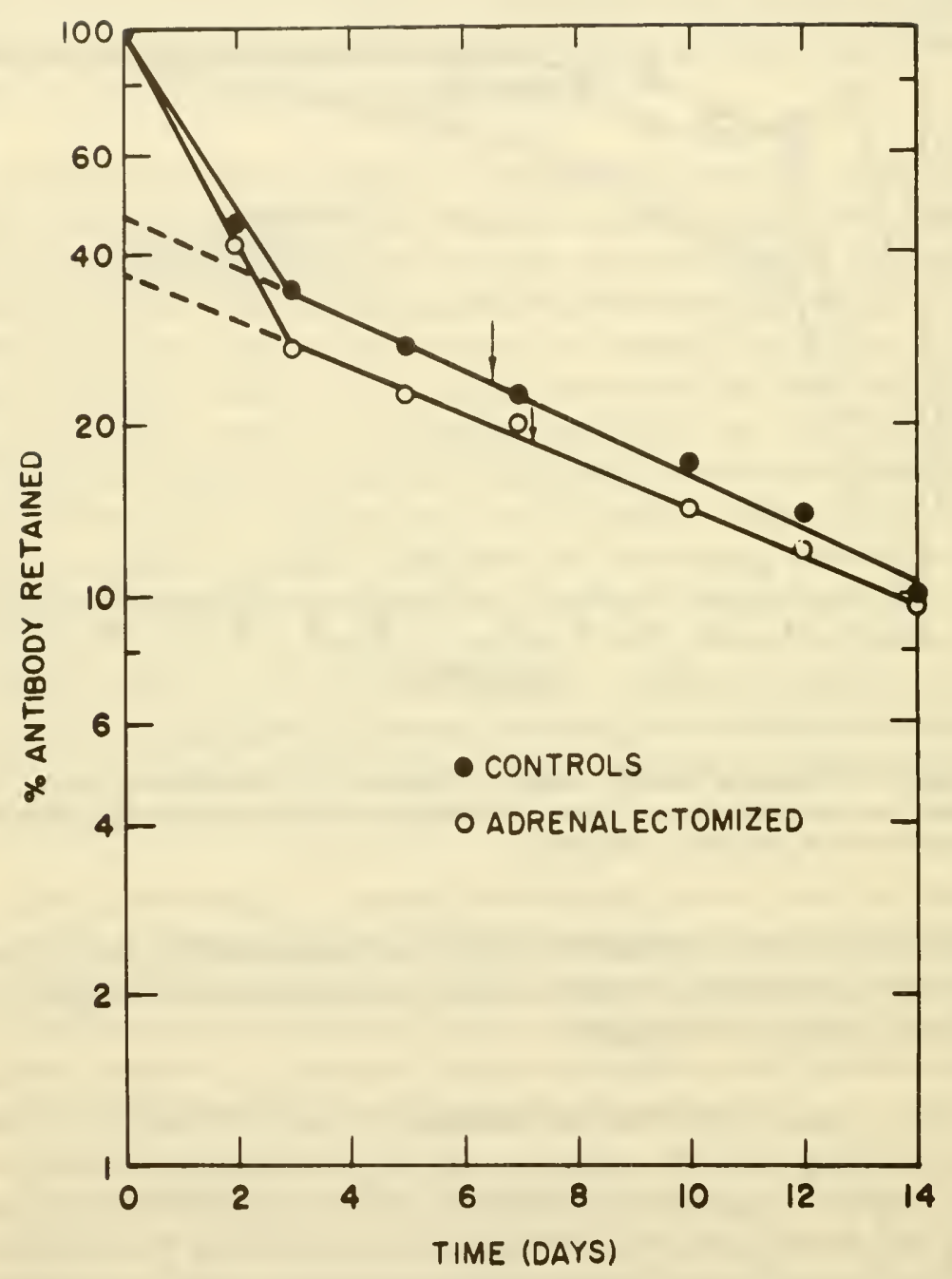

Figure 4. Passive antibody decay in bilaterally adrenalectomized and control rabbits. 


\section{ANTIBODY FORMATION}

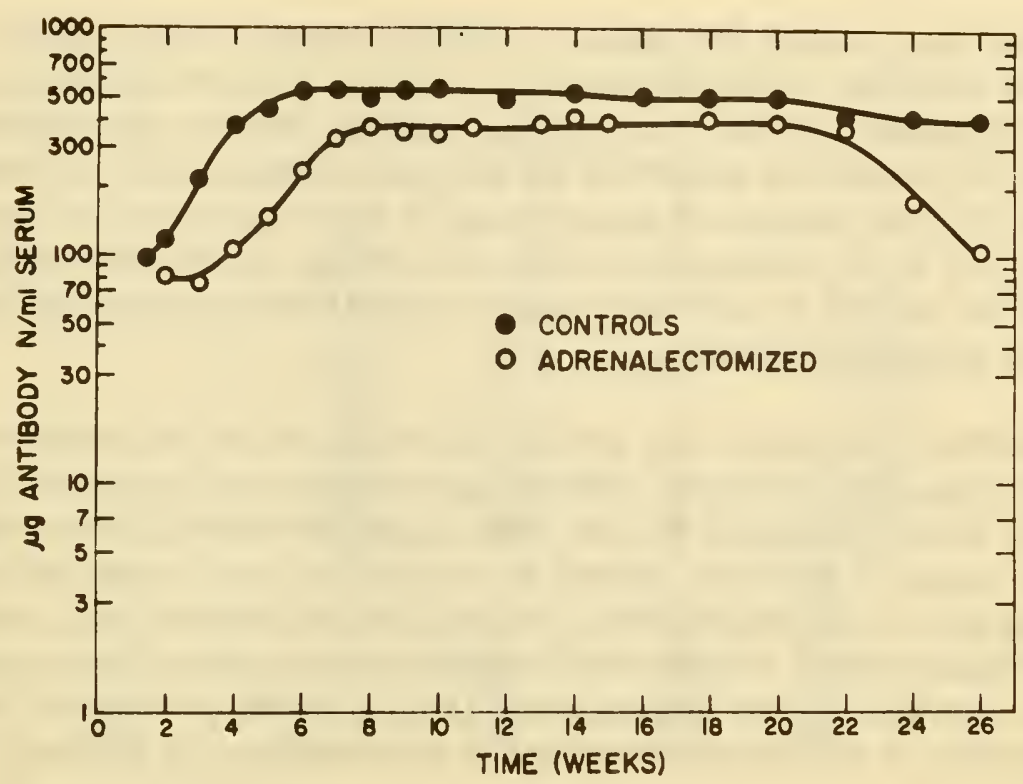

Figure 5. Circulating antibody levels in bilaterally adirenalectomized and control rabbits immunized with BS.t and Freund's adjuvent (10 mg BSA per kg hody wt) at time zero.

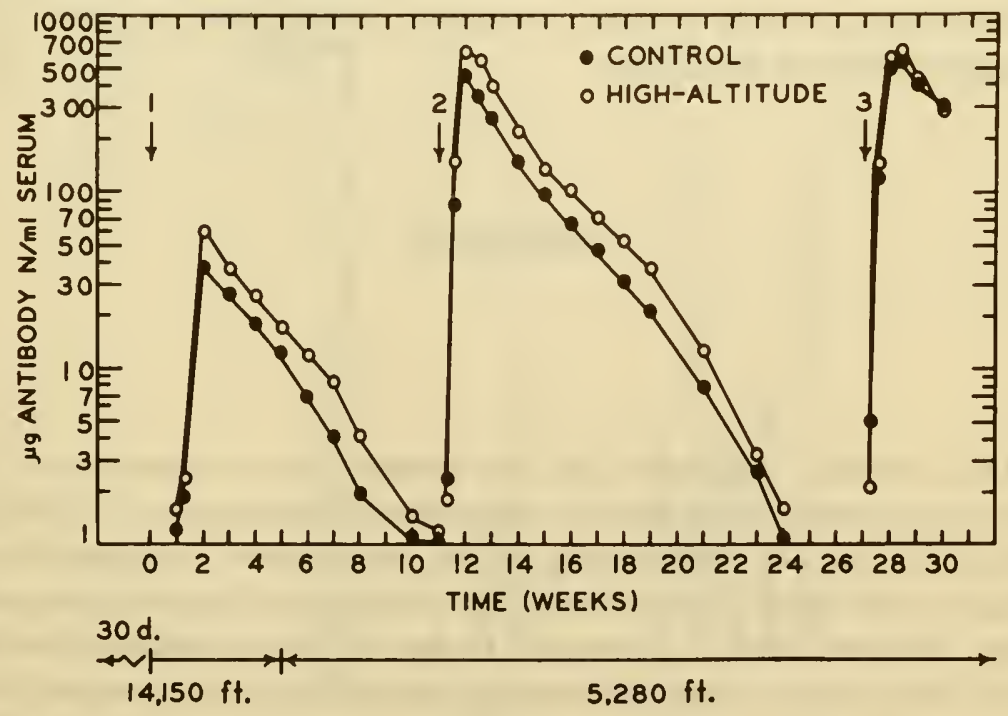

Figure 6. Circulating antiborly levels in rabbits adipted to high aititurle and immunized with BSA (10 mg per $\mathrm{kg}$ body ut) intravenously. 1 inclicates the primary injection, and 2 and 3 indicate the second and third challenge, respectively. 
The next point of information I wish to present is that of the immune response of adrenalectomized animals. Even though there is an abundance of literature dealing with the effect of the adrenal steroids on various aspects of the immuneresponse, little has been done utilizing extirpation experiments. If the reaction of the animal, deprived of its endogenous source of hormone, can be established, then the activity of various available steroid preparations might be more accurately assessed.

Rabbits were bilaterally adrenalectomized in a one-stage operation (Zak, Good, and Good, 1957) using a ventral mid-line approach. They were maintained on 1 per cent saline for drinking water with free access to food, and allowed to recover for 3 to 4 weeks before being used in the experiments. Passive decay of antibody (Fig. 5) in adrenalectomized rabbits was not significantly different from control animals. Active immunization (Fig. 6) shows an apparent net decrease in the immune response of adrenalectomized rabbits.

It has been reported that adrenal steroids depress the immune response. The data presented here, however, indicate that adrenalectomy results in a decreased immune response. These apparently contradictory results present a paradox, and point to the complexity of experiments of this kind.

\section{DISCUSSION}

The immune response can be thought of as composed of two processes (antibody production and antibody decay) occurring simultaneously, but not necessarily at the same rate. It is possible to measure the decay rate of passively administered homologous antibody; however, what is measured in the actively immunized animal is the net result of antibody production and decay. It is conceivable, therefore, that an increase in antibody production might be offset by an increase in antibody decay so that the net level of circulating antibody measured is apparently unchanged. 


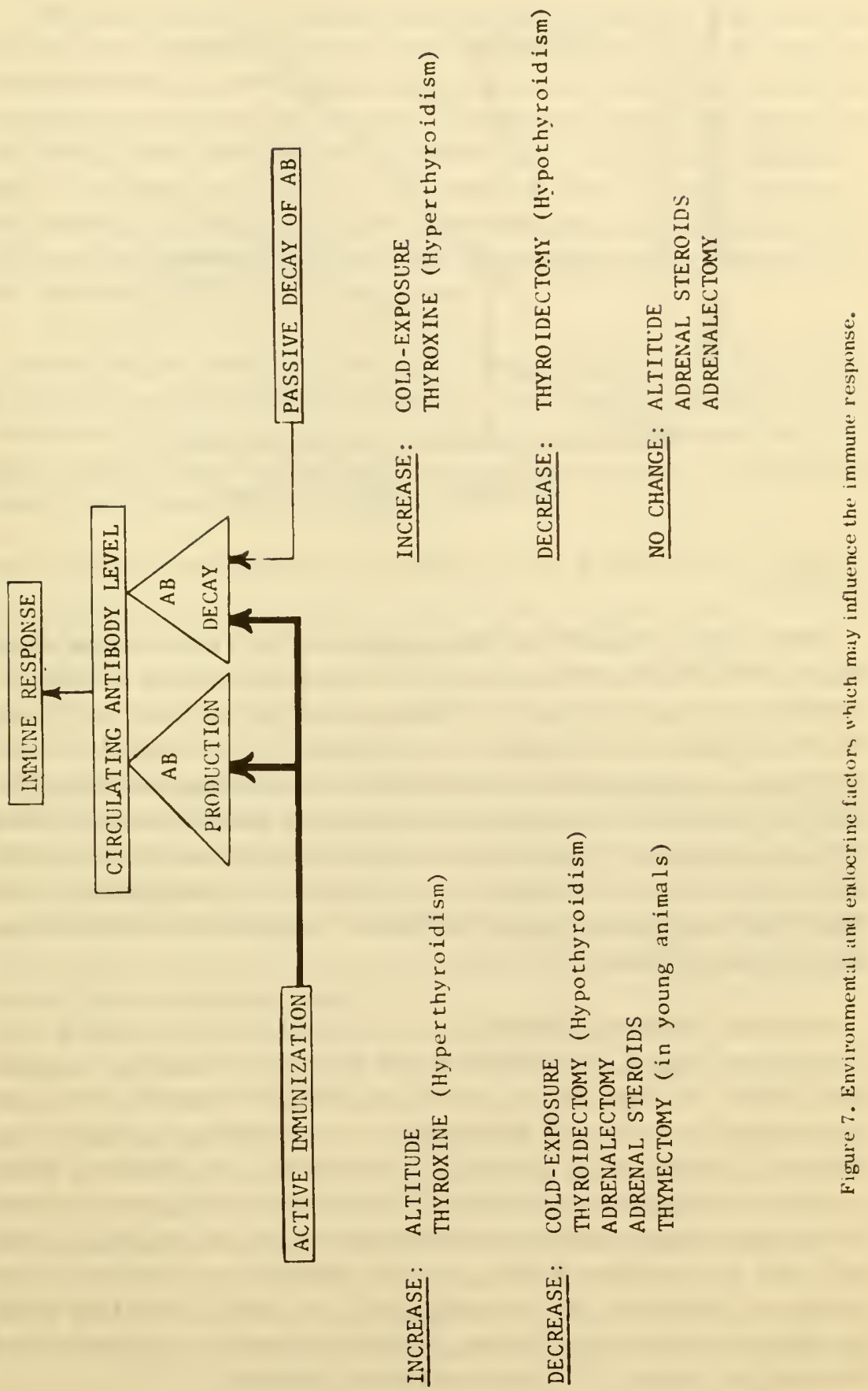




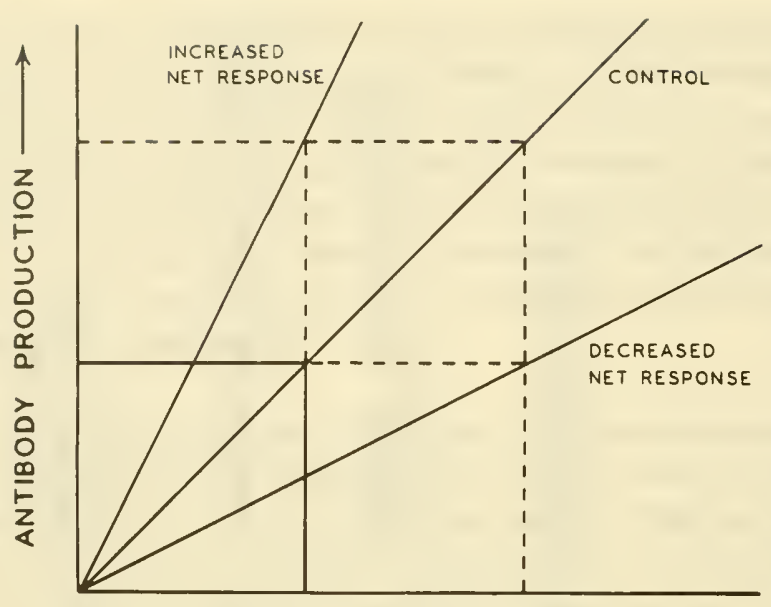

ANTIBODY DECAY $\longrightarrow$

Figure 8. Relationship of antiborly prociuction and antiboly decily to the net immune response.

Some of the complexities of the physiological relationships which might pertain to the immune response of animals exposed to environmental extremes or endocrine imbalancecan bederived from Figure 7. For example, cold exposed animals exhibit a decreased immune response, as measured by circulating precipitating antibody. This may be the result of a) an unchanged rate of production associated with the increased rate of decay, b) a decreased rate of production associated with an increased rate of decay, or c) an increased rate of production which is not of sufficient magnitude to offset the increased rate of decay.

Figure 8 presents a theoretical relationship between antibody production and decay. If production and decay are "balanced" against each other, we then arrive at the line labeled "control". If we now manipulate the animals' physiology so that antibody production or decay is altered, it is possible to arrive at a net response which is either increased or decreased.If production and decay are altered to the same degree and in the samedirection, the net response could still fall on the control line, and the observation would be no net change in response. As a consequence, the actual alteration would be obscured in this test system, and other avenues would have to be explored to arrive at a more definitive answer. 


\section{ANTIBODY FORMATION}

The persistance of antigen (Garvey and Campbell, 1956) and its degradation in the host animal may also be altered under conditions of environmental extremes or endocrine imbalance. Recent studies of antigen disappearance in hibernating ground squirrels (Jaroslow and Smith, 1961) have shown that there was no detectable disappearance of antigen during 14 days of hibernation. After arousal, however, the induction period for antibody formation was shorter than in nonhibernating animals. It appears that this response is a reflection of the physiological state of the animal.

Even though certain physiological changes might be implicated a priori, it is difficult to attribute the net immune response to only one factor. It appears essential to consider the im munophysiological inter-relationships and the functioning of the animal as an integrated unit in host-parasite interactions.

\section{SUMMARY}

Deductions made for host-environmental interactions can often be derived by more than one pathway involving secondary physiological factors which may affect resistance to disease, antibody formation, and antibody decay. The immune response of animals exposed to environmental extremes or endocrine imbalance must be interpreted in the light of available knowledge concerning the functioning of the animal as an integrated unit. 
TRAPANI

LITERATURE CITED

1. Jaroslow, B. N., and D. E. Smith.1961. Antigen disappearance in hibernating ground squirrels. Science 134: 734-735.

2. Lanni, F., M. L. Dillon, and J.W.Beard, 1950. Determination of small quantities of nitrogen in serological precipitates and other biological fluids. Proc. Soc. Exp. Biol. Med. 74: 4-7.

3. Trapani, I. L. 1957. Antibody decay in cold exposed rabbits. (Abstr.) Federation Proc. 16: 436.

4. Trapani, I. L., and D. H. Campbell. 1959. Passive antibody decay in rabbits under cold or altitude stress. J. Appl. Physiol. 14: 424-426.

5. Trapani, I. L., A. Lein, and D. H. Campbell. 1959. The effect of thyroidectomy and thyroxin treatment on the immune response of rabbits. (Abstr.) Federation Proc. 18: 161.

6. Trapani, I. L., A. Lein, and D. H. Campbell. 1959. Passive antibody decay in thyroidectomized rabbits. Nature 183: 982-983.

7. Trapani, I. L. 1960. Cold exposure and the immune response. In International Symposium on Cold Acclimatization, Buenos Aires, Argentina, August, 1959. Federation Proc. 19: Suppl. $5,109-114$.

8. Trapani, I. L. 1961. The immune response in adrenalectomized rabbits. (Abstr.) Federation Proc. 20: 23.

9. Trapani, I. L., and R. T. Jordan. 1962. Antibody formation in rabbits adapted to high altitude. (Abstr.) Federation Proc.:21: 25.

10. Zak, S.J.,R.H. Good, and R.A.Good, 1957. A technique for onestage bilateral adrenalec tomy in the rabbit. Nature $179: 100-102$. 


\section{DISCUSSION}

BERRY: I am very much interested in this report, Dr. Trapani, and would like to point out some of the effects of exposure to a simulated altitude higher than yours; that is, 20,000 feet. One of the things that we have noticed is that mice show an increase in urinary nitrogen excretion. By inference, this would suggest that protein catabolism is increased. If one attains an elevation in nitrogen excretion, this says that the animal is breaking protein down fast. We find it in mice that have been exposed to simulated 20,000 feet for as long as a month, and these animals are about as fully acclimated, as judged by their general metabolism responses as any animals that we have studied. We have kept them for as long as three months, and we can find no difference in animals kept for three months at simulated 20,000 feet than those kept for three or four weeks. We can also get this elevated urinary nitrogen excretion in animals that have been exposed for one day at 1000 feet; and I don't know what this means. This is a very bewildering thing to us.

I wonder if in any of these rabbits urinary nitrogen excretion was determined?

TRAPANI: No. I would suspect that almost any stress imposed on the animal would change its urinary nitrogen excretion. If an animal is put in a cage which is wired with electrical current which goes on and off at intervals, I imagine this sort of a stress might influence nitrogen excretion. Experiments that you just mentioned are somewhat similar to those done by Mefford and $\mathrm{Hale}^{1}$ in which the metabolic interrelationships of cold, heat, and altitude were studied. One of their points, of course, is that there is an increase in nitrogen excretion.

BERRY: What produces the increase in nitrogen excretion, 


\section{TRAPANI}

metabolically?

TRAPANI: Off hand, I don't know.

CAMPBELL: Doesn't the salt balance play an important part?

WALKER: Do these animals lose weight, or eat more, Dr. Berry?

BERRY: They do not lose weight. They are in pretty good metabolic balance as judged by weight.

WALKER: They take in more protein to keep that balance?

BERRY: Yes, but these are complicated relationships.

TRAPANI: The main purpose here, for me, was to point out how complex this really is. These experiments are really not sufficient yet to make a complete story by any means, and the next step planned is to study the immune response of adrenalectomized animals for a considerable period, to elucidate the relationship between the thyroid and the adrenal. Despite all of your excellent experiments utilizing the cold and high altitude chambers, I personally like mountain top laboratories better, since I feel that chambers do offer certain disadvantages.

MONCRIEF: Do your rabbits that you shave still shiver?

TRAPANI: I never saw them shiver.

MONCRIEF: Are they acclimatized to the cold?

TRAPANI: They seem to be. Their body temperature was not much different from room temperature controls.

MONCRIEF: What evidence do you have of increased metabolism of rabbits?

TRAPANI: The metabolic rate, based on oxygen consumption measurements done by open circuit metabolimetry was approxi- 
mately twice that of room temperature controls. Serum protein concentration also increases. This might be an interesting point also to mention. Animals at high altitude have an increased serum protein concentration and a decreased plasma volume. Animals in the cold also have an increased serum protein concentration, and an increased plasma volume. Their plasma volume was measured by Evans blue disappearance and also from the passive antibody decay studies. In the latter case, the amount of antibody injected and the initial antibody concentration in the serum are used to calculate "plasma volume", or perhaps we should call it "antibody space", as compared to Evans blue space.

TUNEVALL: Was the decreased plasma volume at high altitude simply a result of an adaptive polycythemia?

TRAPANI: Yes. From the information just given, it was calculated that animals at high altitude had a total mass of circulating proteins the same as controls, while animals in cold had an increased mass of circulating protein. More specifically, if one makes the proper corrections, the increase in the immune response of animals at high altitude is greater than that which might be expected from a decreased plasma volume.

PREVITE: Have you ever done any experiments in a shorter period of time? For example, have you ever measured antibody titers in response to BSA prior to one week, or isn't that a sufficient amount of time to get a response?

TRAPANI: It's very difficult to detect antibodies before seven days or so.

PREVITE: Have you ever previously immunized your rabbits, waited a sufficient amount of time, and then put them at $-15^{\circ} \mathrm{C}$ ?

TRAPANI: Not in the cold. We did one experiment with rabbits at high altitude simular to what you are thinking about. The first year we took animals up to White Mountain in Cali- 
fornia. Some were immunized in Pasadena before going up, some were immunized when they first got there, some were immunized after seven days, some after a month, and some were just brought up there for a month, then immunized and returned to Pasadena. The only group which seemed to give a fairly clear picture so that we could say, "Well, let's study this one because it's a little simpler," was the group which was brought to a high altitude, adapted for thirty days and then immunized, and the immune response studied while the animals were kept at high altitude. The variation of response in the other groups was too great to merit further study at the time.

PREVITE: I am wondering what would be the antibody response to cold stress within the first few days if one used a rabbit with a known titer? Would you expect antibody titers to decrease?

TRAPANI: By inference, I would say antibody levels may go down; these are given levels of circulating antibody. When the animal is put into the cold, the metabolic rate is increased to overcome the heat load; antibody levels might then decrease as a consequence of an increased turnover rate.

PREVITE: It seems that most of us agree that normally we are warmly clothed when we are outdoors in cold weather. Maybe one is only accidentally going to be stressed by the cold environment. Perhaps it is most important, in analysis of the effects of cold exposure on infectious diseases, to determine the response to this chance exposure.

TRAPANI: I would like to make one more comment that Dr. Berry brought to mind. I think the antigen must be considered not only in terms of its persistance, but also in regard to its chemical nature. The system I used was a soluble one of BSA and anti-BSA. If one uses a viral or bacterial system, these different kinds of antigen might be handled differently by the animals under these situations. Dr. Berry has shown that in animals subjected to high altitudes, resistance to bacterial infection is decreased, whereas resistance to viral infection is 


\section{ANTIBODY FORMATION}

increased. At present, I am doing an experiment in collaboration with Dr. M. L. Cohn in which Guinea pigs kept at $-4^{\circ} \mathrm{C}$ at the Denver altitude or on top of Mount Evans, are infected with Mycobacterium tuberculosis. We just finished infecting our animals by inhalation techniques last week, and whether or not the results will come out similar to yours won't be known for another month or so. 



\title{
QUALITATIVE AND QUANTITATIVE ASPECTS OF THE IMMUNE RESPONSE UNDER CONDITIONS OF COLD EXPOSURE
}

\author{
William T. Northey \\ Department of Microbiology \\ Arizona State University \\ Tempe, Arizona
}

\section{ABST RACT}

Rabbits have been exposed to lowered environmental temperatures and immunized with various protein antigens. In certain experiments, the immunization and bleeding schedules have also been changed. Serum samples from these animals, as well as a "control" group receiving an identical immunization schedule, have been analyzed by a number of immunological and immunochemical techniques. To detect any possible qualitative differences in the serum samples as a result of cold exposure, a number of analyses have been conducted. Among the techniques used are; Ouchterlony gel diffusion, immunoelectrophoresis, and starch gel electrophoreses. Quantitative differences in the serum proteins have been studied by a determination of $\mathrm{A} / \mathrm{G}$ ratios and by a comparison of the serum globulins by paper electrophoresis. Precipitin titrations on rabbit sera have been conducted using the ring test, and total antibody nitrogen has been measured by the quantitative precipitin technique.

It may seem unusual to many in this group that Arizona State University, which is located in the heart of the Sonoran desert, would be an institution in which studies concerned with "cold stress" are conducted. However, for the past two years, including the months of June, July and August when the outside temperature exceeds $37.7^{\circ} \mathrm{C}$ almost daily, we have, through the marvels of modern day refrigeration, continued our studies into the immunological aspects of this fascinating and challenging problem.

Many observations concerning the influence cf environmental temperature have been made on experimental animals and human beings as well. But the seasonal incidence of many diseases has never been explained, although it has been suggested by some investigators that environmental temperatures may influence the frequency with which a disease may occur, as well as the severity 
of the infection (Moragues and Pinkerton, 1944; Jungeblut et al., 1942). In numerous studies on the influence of environmental temperature on both human and experimental infection, conflicting results have been reported, even when the same infectious agents and the same animals were used. In the majority of these studies, no attempt was made to measure the anitbody responsequantitatively of animals under "cold stress". A notable exception to this has been work of Campbell, Trapani and Sutherland (Campbell, 1951; Sutherland etal., 1958) whose studies on the sera of cold exposed rats and rabbits has provided valuable information concerning passive antibody decay, changes in the serum proteins, and alterations in the antibody level and blood chemistry. I attempted to measerequalitatively and quantitatively the immune response of rabbits exposed to lowered environmental temperatures. To achieve a high degree of sensitivity, antigenantibody systems of knownhigh reactivity were used, and the results of the immunization of both "normal" and "cold exposed" rabbits studied. Through the use of strongly reacting protein antigen-antibody systems, a qualitative measure of the antibody response was made through the use of such techniques as Ouchterlony gel diffusion, immuno-electrophoresis, starch gel electrophoresis, and paper electrophoresis. Quantitative determinations included titrations of antibody levels by the conventional "ring" precipitin technique, and by the much more precise method of micro-quantitative precipitin analysis. An attempt was made to obtain quantitative results of gel diffusion studies by measuring the intensity and homogeneity of the antigen-antibody reaction in terms of the amount of precipitate formed. The objective was todetermine (l) the sensitivity of the immune mechanism of animals during cold exposure versus the "normal", that is, the multiplicity of the antibody response, and (2) the "type" of antibody produced during cold exposure, that is, the affinity or avidity for its specific antigen of the antibody produced by the "cold exposed"versus "normal" animal. The specific objective of the qualitative studies was to deter mine the number of multiple antigenantibody systems which can be observed in each of the groups when identical immunization schedules are followed. Immunization with the same multiple antigen system will provide infor mation regarding the sensitivity and selectivity of the immune mechanismunder conditions of the cold exposure. By studying both the qualitative and quantitative aspects of the problem, one should be able to draw certain conclusions regarding the response of the "cold exposed" ani- 
mals in terms of (1) the ciegree of response, for example, the total amount of antibody produced, (2) the rate of appearance of antibody, (3) the "type" of antibody produced, and (4) the influence of the period of immunization and/or cold exposure on the response of animals to major and minor antigens when immunized with a multiple antigen system.

This information may serve to elucidate the role of the "specific" factor of immunity, that is, circulating antibody during periods of cold exposure, and at the sametime serve to clarify the response of the immune mechanism to immunization with multiple antigens both during and prior to cold exposure.

In all of these studies, the rabbit was the experimental animal of choice. The animals were housed in a walk-incold room maintained at a temperature of $4^{\circ} \mathrm{C}$. Prior to the beginning of the immunization schedules, the rabbits were allowed to "adapt" for a period of one week, after which they were clipped until fur remained only on the head and the extremities. New fur was periodically clipped. The animals were given food ad libitum, and water was changed frequently. Open wire cages were used to allow free movement of air. Only one rabbit was housed in each cage to prevent huddling. In most of the studies, rabbits weighing approximately 2.5 to $3.0 \mathrm{~kg}$ were immunized with three weekly intra-muscular injections of equal parts of antigen and Freund's adjuvant (Freund, 1947).

Blood samples were obtained via cardiac puncture, the serum separated and merthiolate added in a 1:10,000 final concentration. All of the rabbits used in these studies were carefully selected in order to control genetic variations. Litters of six or more were raised for this investigation, and each litter was divided into equal study groups of experimental and control animals. The serum samples were then subjected to a variety of immuno-chemical analyses which were designed to detect any difference in the serum proteins of the "cold exposed" versus the "non-cold exposed" rabbits.

The immune response of an animal to the administration of an infective agent is best measured in terms of the antibody formed and directed against the microorganism and its antigenic spectrum. 


\section{NORT HEY}

While the original aim of this investigation was to determine whether or not differences exist in response to antigenic stimulus in "cold stressed" animals as opposed to "normal" animals following immunization with various selected microorganisms, preliminaryexperiments indicated that these systems were not sensitive enough, nor did they possess a high degree of specificity. Early experiments were designed to measure qualitative and quantitative differences in response to the injection of various selected microorganisms such as Salmonella typhimurium and Diplococcus pneumoniae. Analysis of the sera collected from animals challenged in this manner proved to be difficult in that as the gel diffusion technique best serves as a measure of the "soluble" antigen content of a microbial suspension, the degree of sensitivity which could be attained using microbial anti-microbial systems was inadequate to detect differences in the "cold stressed" and control animals. Because of the high degree of reactivity inherent to antigen-antibody systems involving complex soluble protein antigens, a number of systems involving these antigens were selected for investigation. As a result, the original experimental protocols were modified to include a number of new systems which are of sufficient complexity and sensitivity for a study of this type. These new studies included such protein antigens as human serum, egg albumin (Ea), bovine serum albumin (BSA), and whole bovine serum. These protein antigens, although not implicated in the usual "infective process", serve as a reliable index of the degree of sensitivity and selectivity by the antibody forming mechanisms.

\section{METHODS}

\section{Gel Diffusion}

One of the most sensitive methods of measuring the antibody response is through the use of the gel diffusion technique devised by Cuchterlony (1949). In this investigation a 1 per cent solution of Ionagar Number 2 (Consolidated Laboratories, Chicago Heights) was used to prepare the gel. The pattern was cut in the agar using a Fineberg Agar Gel Cutter Number 1802, manufactured by the 


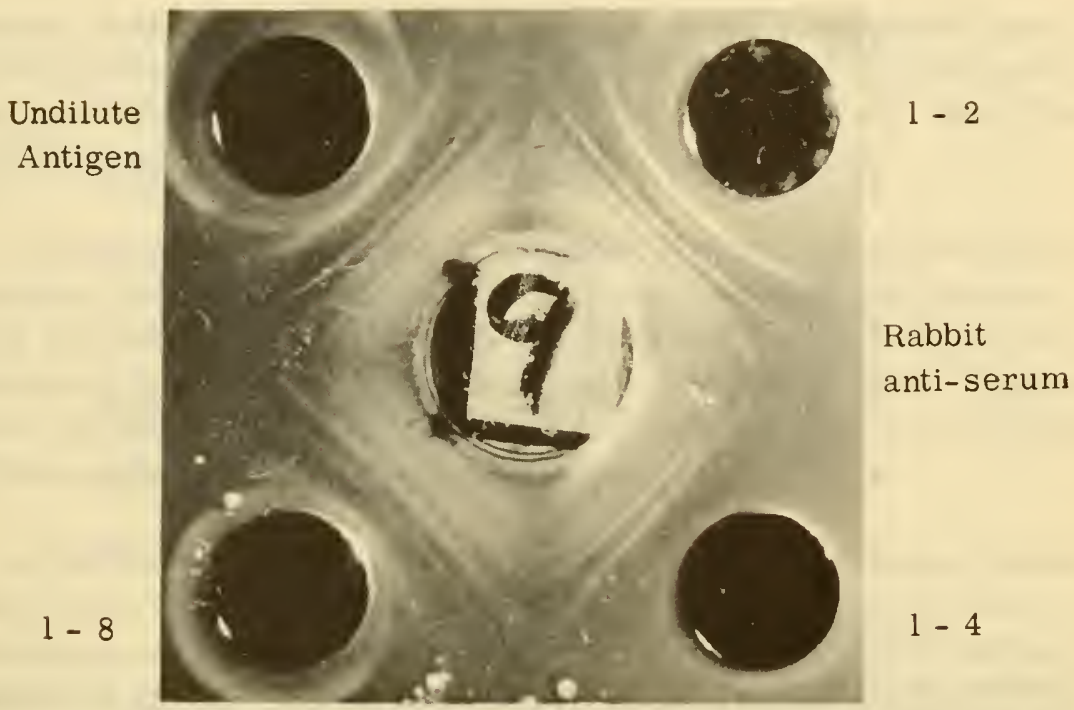

Figure 1. Ouchterlony gel diffusion analysis of bovine serum--rabit antibovine serum.

Shannon Scientific Company of London , $_{2}$ and distributed in this country by Consolidated Laboratories. This pattern consists of a center well surrounded by four wells equidistant from it. These four wells were used for the various antigen dilutions. In order to approximate more closely the region of optimal proportions, four samples of antigen were tested in each case; that is, undilute, $1: 2$, $1: 4$, and 1:8. Plates were read at appropriate intervals in order to determine the time of precipitation of the firstreacting components, and the results of each of the readings were recordeci on master sheets designed for this purpose. Readings in all cases were taken from the antigen-antibody concentrations which gave the most definitive results. A sample plate is shown in Figure 1.

For the data obtained to be best evaluated, it became necessary to adopt a more accurate method of measurement based on statistics. The method of choice was the Mann-Whitney U test. This nonparametric test is a useful alternative to the parametric " $t$ " test when the measurement in the research is weaker than interval scaling.

Aladjem et al,(1959) have reported that the time lapse preceding 


\section{NORTHEY}

$\begin{array}{ccccc}\text { Sample } & \text { N } & \text { R-Cold } & \text { R-Normal } & \text { U* } \\ 1 & 9 & 85.500 & 85.500 & 40.500 \\ 2 & 9 & 86.500 & 84.500 & 39.500 \\ 3 & 9 & 66.000 & 105.000 & 21.000 \\ 4 & 9 & 68.500 & 102.500 & 23.500 \\ 5 & 9 & 65.500 & 105.500 & 20.500 \\ 6 & 9 & 70.500 & 100.500 & 25.500 \\ 7 & 9 & 63.000 & 108.000 & 18.000\end{array}$

Table I. Qualitative evaluation of precipitates in gel diffusion of sera from "normal" and "cold exposed" rabbits. *U value of Mann-Whitney U test at 0.05 significance level $=$ 17. Antigen-whole bovine serum.

$\begin{array}{ccccc}\text { Sample } & \text { N } & \text { R-Cold } & \text { R-Normal } & U * \\ 1 & 9 & 85.500 & 85.500 & 40.500 \\ 2 & 9 & 83.500 & 87.500 & 38.500 \\ 3 & 9 & 80.000 & 91.000 & 35.000 \\ 4 & 9 & 82.500 & 88.500 & 37.500 \\ 5 & 9 & 68.500 & 102.500 & 23.500 \\ 6 & 9 & 69.500 & 101.500 & 24.500 \\ 7 & 9 & 85.000 & 85.500 & 40.500\end{array}$

Table II. Quantitative evaluation of precipitates ingeldiffusion of sera from "normal" and "cold exposed" rabbits. *U value of Mann- Whitney Utest at 0.05 significance level= 17. Antigen-whole bovine serum. 


\section{IMMUNE RESPONSE IN COLD EXPOSURE}

visable precipitation in double diffusion tests is dependent upon three factors: (1) the diffusion co-effecient of each of the reactants, (2) their absolute concentrations, and (3) the speed with which the antigen-antibody front can form insoluble complexes.

Assuming that each of the rabbit antibody preparations possesses an equal diffusion co-efficient, and using the same antigen preparation for both systems, the time of appearance of each of the precipitating bands on the Ouchterlony gel diffusion plate should depend upon the concentration of the antibody and/or the affinity or avidity of the antibody for its homologous antigen.

In our evaluation of these data, three methods of measurement were used. In order to analyze thedata, (1) the total number of precipitating antigen-antibody complexes was measured at each reading; (2) in an attempt to evaluate the results quantitatively, each of the precipitates was visually estimated and ranked with respect to the total amount and homogeneity of precipitate; and (3) the time of appearance of each of the precipitating bands was recorded. Precipitates were graded one through four based upon assigned criteria, with the sharpest and most well-defined bands being assigned the highest number. Quantitative evaluations were based on the number of bands of precipitate times the intensity of each precipitate; for example, a gel diffusion plate having four sharp, heavy bands of precipitate and one faint, poorly-defined precipitate was assigned a total value of $17(4 \times 4+1 \times 1)$. All of the data, both qualitative and quantitative, were subjected to statistical evaluation by the MannWhitney $U$ test. The results of one of these studies are given in Tables I and II.

From these tables it may be seen that a statistical evaluation of both the qualitative data based on the number of precipitating bands in the Ouchterlony gel diffusion plates and the quantitative data based on the number of bands times the intensity of the precipitate failed to reach a level of significance in the Mann- Whitney U test. The $U$ value at the 0.05 significance level is equal to 17 . In study groups in which the larger of two independent samples is smaller than 9 , tables for $U$ values are notavailable and the $P$ value is calculated directly (Table III). It may be noted in Table III that differences which are significant at the 0.05 level are obtained in sample 2 
NORT HEY

$\begin{array}{cccccc}\text { Sample } & \text { N } & \text { R-Cold } & \text { R-Normal } & U & P \\ 1 & 3 & 0 & 0 & & \\ 2 & 3 & 6 & 4 & 0 & .050 \\ 3 & 3 & 12 & 11 & 2 & .200 \\ 4 & 3 & 11 & 12 & 4 & .500 \\ 5 & 3 & 15 & 12 & 1 & .100 \\ 6 & 3 & 20 & 18 & 1 & .100 \\ 7 & 3 & 15 & 16 & 4 & .500\end{array}$

Table 111. Qualitative evaluation of precipitates in gel diffusion of sera from "normal" and "cold exposed" rabbits. Antigen-egg albumin (Eá).

of the egg albumin anti-egg albumin system. However, a significant level was not attained at any other sample in this experiment. An occasional significant value was also found in other experiments, but these findings were not consistent with most of the data. To date, over 500 serum samples have been evaluated in this manner. The same method has also been applied to measurements of the time of precipitation. The results of one series of measurements at closely spaced time intervals is given in Table IV.

\section{"Ring" Precipitin Titrations}

The "interfacial technique" has been used extensively as a measure of the antibody "titer" of immune sera. In these studies, serum samples from both study groups were titrated for antibody content using different antigens and varying bleeding schedules. The result of one of these tests using egg albumin as antigen is shown in Table $\mathrm{V}$.

The antibody titrations by the precipitin "ring" technique failed to reveal any consistent trend toward higher antibody levels in either of the study groups. However, when the less complex antigens, egg albumin (Ea) (Table V) and bovine serum albumin (BSA) were used, the antibody levels were somewhat higher in the "cold exposed" group, whereas the animals maintained at room temperatures and 


\section{IMMUNE RESPONSE IN COLD EXPOSURE}

\section{Qualitative Evaluation}

\begin{tabular}{lccccc} 
Sample & Time & N & R-Cold & R-Normal & U* \\
$2-1$ & $8 \mathrm{hr}$. & 9 & 85.500 & 85.500 & 40.500 \\
$2-2$ & $12 \mathrm{hr}$. & 9 & 88.500 & 82.500 & 37.500 \\
$2-3$ & $20 \mathrm{hr}$. & 9 & 81.000 & 90.000 & 36.000 \\
$2-4$ & $28 \mathrm{hr}$. & 9 & 87.500 & 83.500 & 38.500 \\
$2-5$ & $36 \mathrm{hr}$. & 9 & 86.500 & 84.500 & 39.500 \\
Quantitative Evaluation & & & \\
\hline Sample & Time & $\mathrm{N}$ & $\mathrm{R}-\mathrm{C} 01 \mathrm{~d}$ & $\mathrm{R}-\mathrm{N}$ ormal & \\
$2-1$ & $8 \mathrm{hr}$. & 9 & 85.500 & 85.500 & 40.500 \\
$2-2$ & $12 \mathrm{hr}$. & 9 & 84.000 & 87.000 & 39.000 \\
$2-3$ & $20 \mathrm{hr}$. & 9 & 72.500 & 98.500 & 27.500 \\
$2-4$ & $28 \mathrm{hr}$. & 9 & 84.000 & 87.000 & 39.000 \\
$2-5$ & $36 \mathrm{hr}$. & 9 & 91.500 & 79.500 & 34.500
\end{tabular}

Table IV. Statistical evaluation of gel diffusion precipitates based on time of precipitation. ${ }^{*} U$ value of Mann-Whitney $U$ test at 0.05 significance level=17. Antigenwhole bovine serum.

Number of Days

following Initial Injection
Mean Antibody Titer Mean Antibody Titer* Cold exposed
Non-Cold exposed

$\begin{array}{lll}4 & 1-2000 & 1-1600 \\ 10 & 1-3000 & 1-3000 \\ 17 & 1-6000 & 1-4000 \\ 24 & 1-8000 & 1-5000 \\ 30 & 1-10,000 & 1-7000\end{array}$

Table V. Mean precipitation titers of "normal"and "cold exposed" rabbits immunized with egg albumin (Ea). *Mean titer calculated on the basis of antibody titers obtained from precipitin titrations of 10 sumples of rabbit antiserum. 


\section{NORT HEY}

using the human serum antigen attained a slightly higher level of antibody. Of interest too is that in the group in which daily blood samples were taken, the additional "stress" created by cold exposure did not significantly alter a steady rise in the antibody level (Table VI and Table VII).

\begin{tabular}{ccc}
$\begin{array}{c}\text { Number of Days } \\
\text { Following } \\
\text { Initial Injection }\end{array}$ & $\begin{array}{c}\text { Mean Antibody Titer } \\
\text { Cold exposed }\end{array}$ & $\begin{array}{c}\text { Mean Antibody Titer } \\
\text { Non-Cold exposed }\end{array}$ \\
\hline 3 & $1-2500$ & $1-3000$ \\
6 & $1-5000$ & $1-8000$ \\
9 & $1-5000$ & $1-10,000$ \\
12 & $1-5000$ & $1-10,000$ \\
18 & $1-2400$ & $1-10,000$ \\
24 & $1-6500$ & $1-10,000$ \\
48 & $1-7000$ & $1-10,000$
\end{tabular}

Table VI. Mean precipitin titers of "normal" and "cold exposed" rabbits immunized with human serum. *Mean titer calculated on the basis of antibody titers abtained from precipitin titrations of 6 samples of rabbit antiserum.

$\underline{\text { Starch Gel Electrophoresis }}$

The technique of electrophoresis in starch gel offers a method of increased sensitivity over that of paper electrophoresis, and under proper conditions, it is possibletoresolve as many as fifteen components in human serum (Moretti et al., 1959). This method was utilized for a comparison of the sera from "normal" and "cold exposed" animals in order to detect the possible presence of any "abnormal proteins" which might be formed as a result of cold exposure. Conversely, the failure of the "cold exposed" animal to form any of the "normal" serum sub-fractions could also be recognized. Simultaneous analysis of sera from both "cold exposed" and "normal" rabbits immunized with antigens of varying complexity provides a convenient method for these evaluations.

Samples were analyzed by starch gel electrophoresis in an appa- 


\section{IMMUNE RESPONSE IN COLD EXPOSURE}

\begin{tabular}{|c|c|c|c|}
\hline $\begin{array}{l}\text { Number of Days } \\
\text { following } \\
\text { Initial Injection }\end{array}$ & $\begin{array}{l}\text { Mean Antibody Titer } \\
\text { Cold exposed }\end{array}$ & $\begin{array}{r}\text { Mean } \\
\text { Non }\end{array}$ & $\begin{array}{l}\text { Antibody Titer } \\
\text { Cold exposed }\end{array}$ \\
\hline 1 & - & & - \\
\hline 2 & - & & - \\
\hline 3 & - & & - \\
\hline 4 & - & & - \\
\hline 5 & $1-50$ & & $1-20$ \\
\hline $6 \star \star$ & $1-60$ & & $1-20$ \\
\hline 7 & $1-60$ & & $1-20$ \\
\hline 8 & $1-100$ & & $1-60$ \\
\hline 9 & $1-60$ & & $1-60$ \\
\hline 10 & $1-100$ & & $1-60$ \\
\hline 11 & $1-100$ & & $1-60$ \\
\hline 12 & $1-250$ & & $1-60$ \\
\hline $13 \star \star$ & $1-500$ & & $1-300$ \\
\hline 14 & $1-300$ & & $1-500$ \\
\hline 15 & $1-1500$ & & $1-1000$ \\
\hline 16 & $1-1500$ & & $1-1000$ \\
\hline 17 & $1-1500$ & & $1-1500$ \\
\hline 18 & $1-3000$ & & $1-3000$ \\
\hline 19 & $1-6000$ & & $1-4000$ \\
\hline 20 & $1-6000$ & & $1-4500$ \\
\hline 21 & $1-7000$ & & $1-5000$ \\
\hline 22 & $1-7000$ & & $1-6000$ \\
\hline 23 & $1-8000$ & & $1-7000$ \\
\hline 24 & $1-8000$ & & $1-7500$ \\
\hline 25 & $1-10,000$ & & $1-8000$ \\
\hline
\end{tabular}

Table VII. Mean precipitin titers of "nor mal" and "cold exposed" rabbits immunized with bovine serum albumin (BS.1). *Mean titer calculated on the basis of antibody titers obtained from precipitin titrations of nine samples of rabbit antiserum. **Dates of immunization. 


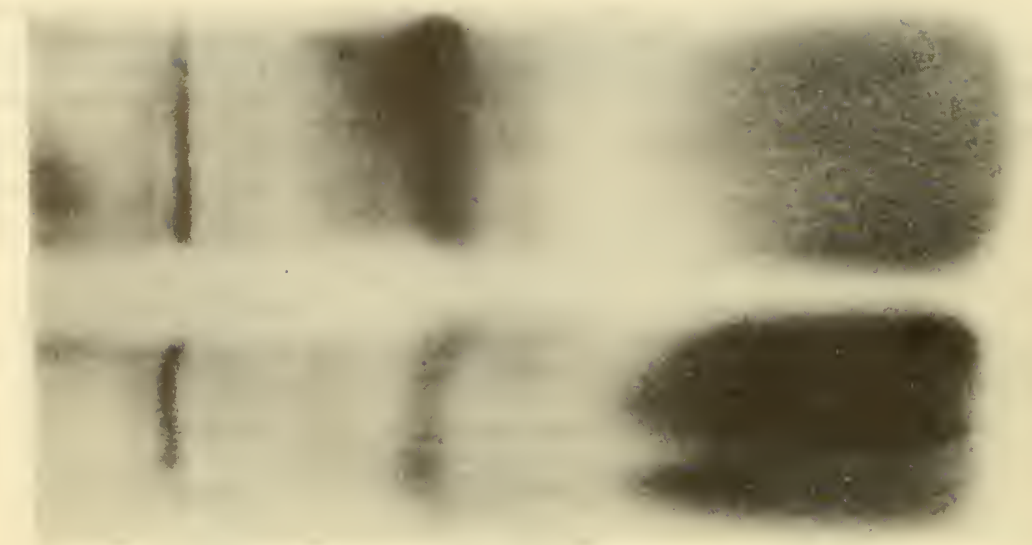

Figure 2. Starch gel electrophoresis of sera from "cold exposed" (bottom of picture) and "non-cold exposed" (top of picture) rabbits.

ratus of our own design which utilized a borate buffer having an ionic strength of 0.01 in the gel and an ionic strength of 0.03 in the borate bridge. In all cases, samples were analyzed simultaneously using a plastic trench which accommodated two samples at once. A piece of filter paper was saturated with the serum and placed in a slit in the gel. Samples representing both the "cold stressed" samples and "normal" samples were run side by side at a current of 250 volts 5 ma per sample for a five hour period. At the end of the migration period, the strips were cut and stained with amido (black) Schwartz. Permanent records were maintained by sketching the pattern on graph paper and by photographs. A representative starch gel strip is shown in Figure 2.

Thus far, a total of more than 300 serum samples from "cold exposed" and non-cold exposed animals have been analyzed by starch gel electrophoresis, and a critical evaluation of the data has failed to reveal any striking differences. The presence of any "abnormal proteins" in the sera of cold exposed animals was not detected.

However, a serum fraction, which has tentatively been identified as one corresponding to the B lipoprotein of paper electrophoresis (the alpha-2 lipoprotein of immuno-electrophoresis), has been found to be weak or absent in a number of serum samples from 


\section{IMMUNE RESPONSE IN COLD EXPOSURE}

"cold exposed" animals when compared to the sera from animals maintained at normal environmental temperatures. This fraction has been reported to contain 55 to 66 per cent of the total conjugated lipid in human serum (Urial and Grabar, 1956). A second observation of interest, although not necessarily significant, is that the serum fractions observed on starch gel and stained by Amido (black) Schwartz stain consistently appeared to be more distinct and well defined in the sera of the "cold exposed" animals.

\section{Immuno-electrophoresis}

Because of the high degree of resolution possible by immunoelectrophoresis, this technique has proved to be invaluable in the identification of complex antigenic mixtures from a variety of sources (Growle, 1961). We felt that this method would prove to be useful in determining the sensitivity and/or selectivity of the immune mechanism because the sera of animals immunized during periods of cold exposure could be compared with those of animals maintained at "normal" temperature and immunized in an identical manner. The ability of the antibody forming mechanism to respond to a heterogeneous spectrum of antigens present in varying concentrations should provide a sensitive and reliable index of the qualitative immune response. Sera from "cold exposed" and "normal" rabbits were analyzed simultaneously by immuno-electrophoresis, and the results were compared. Serum samples from each of the groups were allowed to migrate in the gel under the influence of an electric current. Following the migration period, the antigen was applied to a center trough and allowed to diffuse into the gel and react simultaneously with each of the separated antiserum preparations. The technique used is shown in Figure 3.

To date, no significant differences have been observed in the qualitative response of "cold exposed" and "normal" animals as measured by analysis of their sera by immuno-electrophoresis. However, application of this technique has been restricted to only forty serum samples due to insufficient time. This phase of the investigation is currently being intensified, and final judgmentconcerning the applicability of this technique to these studies must await completion of additional experiments. 


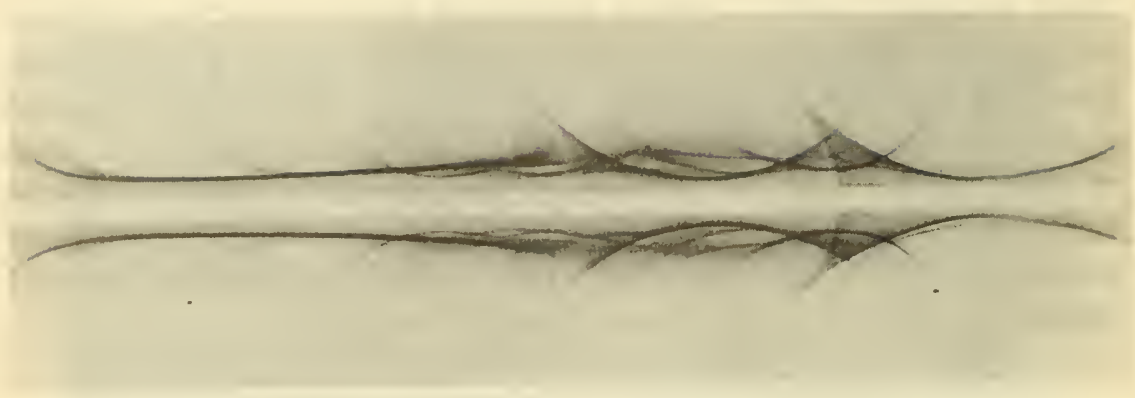

Figure 3. Immuno-electrophoretic analysis of rabbit anti-human serum antibody in "cold exposed" (top of picture) and "non-cold exposed" (bottom of picture) rabbits. 1. Barbitol buffer strength ionic strength 0.375. 2. Stain - thiazine red R.

\section{Quantitative Precipitin Analysis}

A limited number of serum samples have been analyzed by the micro-quantitative precipitin method of Lanni (Lanni et al., 1950). The results of this analyses are given in Table VIII.

$\begin{array}{lcc} & \text { N } & \begin{array}{c}\text { Antibody Protein } \\ \mathrm{mg} / \mathrm{ml}\end{array} \\ \text { Cold Exposed } & 8 & 0.428 \pm 0.1548 \% \\ \text { Non-Cold Exposed } & 8 & 0.3716 \pm 0.0767\end{array}$

Table VIII. Quantitative precipitation analyses of sera from "cold exposed" and "noncold exposed" rabbits.

It may be noted from the table that the cold exposed rabbits gave slightly higher levels than the non-cold exposed group. This finding is in accord with that of Trapani and Campbell who noted somewhat higher levels in the plasma proteins of cold exposed $\left(1^{\circ} \mathrm{C}\right.$ to $-15^{\circ}$ C) rabbits (Sutherland et al., 1958). 
We are currently intensifying this phase of the investigation in an attempt to obtain a much larger sample in order to reach a definitive conclusion. More animals are necessary to lower the standard error to an acceptable level, although population variation here is small, and consequently, this initial estimate of serum protein levels is statistically quite accurate.

\section{Paper Electrophoresis}

To date, a total of more than 350 serum samples have been analyzed by paper electrophoresis. In addition, approximately 75 serum samples have been analyzed for glyco-protein content. The results of these evaluations are not available at this time, and are currently being statistically analyzed using the Fisher " $t$ " test by the General Electric computer center at Arizona State University.

\section{DISCUSSION}

An evaluation of the data presented here concerning the effect of "cold exposure" on the immune response of rabbits indicates that any "differences" attributable to "cold" per se from both the qualitative and quantitative aspects of immunity are of insufficient magnitude to draw any definitive conclusions.

A fundamental consideration in any investigation of this type concerns what may be construed as "stress" conditions. Again citing the work of Sutherland, Trapani, and Campbell (1958) the rectal temperature of rabbits maintained at $4^{\circ} \mathrm{C}$ was not significantlydifferent from that of animals maintained at a room temperature of $18^{\circ} \mathrm{C}$. In the studies reported here, however, a temperature of $4^{\circ} \mathrm{C}$ was considered to be a condition of "stress" for rabbits shaved of the bulk of their pelage. This assumption was substantiated by the fact that the animals tended to huddle, their skin was cold to the touch, some shivering was observed, and a sig- 
nificantly large number of animals succumbed from non-specific causes during the course of the various studies in the cold exposed group compared to deaths in those maintained at room temperature.

The quantitative evaluation of sera from each of the groups has provided some interesting information regarding the immune response under conditions of cold exposure. Antigens of varying complexity were used, and the response of the animals measured. The comparatively less complex antigens, egg albumin (Ea) and bovine serum albumin (BSA), provide a sharp contrast to the very complex human serum and bovine serum in terms of multiplicity of antigens to which the antibody forming cells must respond. The failure to find a significant qualitative difference in the experimental and "control" groups indicates that cold exposure does not appreciably affect the total response of an animal to multiple antigen systems. The level of the response, as well as the time required for antibody response, did not differ significantly in any of the gel diffusion studies. In spite of the failure to attain statistical significance in these studies, it must be remembered that these data do not provide a final critical measure of antibody response during hypothermia. Campbell et al. (1951) and Sutherland et al. (1958) have measured the rates of antibody decay during both active immunization and passively administered antibody. These authors report an increased rate in decay of both actively formed and passively administered antibody in cold exposed rabbits. Extrapolation of these findings to the data presented here and increased rate of "decay" may provide a more sensitive measure of the actual difference, and result in the weighing in favor of an increase in antibody production in the "cold exposed" animals. Such an extrapolation is, of course, impossible on the basis of our present knowledge of the mechanisms of protein metabolism and protein turnover in the immunized animal.

It should be pointed out that I am well aware of the inherent dangers in lending too much credence to the results of an evaluation by gel diffusion. Numerous investigators have demonstrated that this procedure is dependent upon a variety of physico-chemical factors, and that this technique, regardless of how critically applied, is subject to error (Glenn, 1959; Jennings et al., 1962). 


\section{IMMUNE RESPONSE IN COLD EXPOSURE}

Antibody titrations by the "ring" precipitin method are at best only a crude approximation of the antibody concentration in a serum sample. Because dilutions of antigen rather than antibody are used as a measure of "antibody level", the validity of such titrations has been widely criticized (Roffel, 1961). In spite of this fact, this technique has received wide application, and in this investigation, these titrations have provided a simple and convenient method for approximating antibody levels atvarious dates during the bleeding schedule, and will be supplemented by the vastly more sensitive microquantitative precipitin analyses when time permits.

Baker and Sellers (1960) have observed in "cold exposed" rats the presence of a plasma protein component which they report has a similar electrophoretic mobility to the "transferrin" component of human serum. This component, also known as siderophilin, serves to bind iron in the circulating blood and migrates as a B globulin.

While we did not find the presence of a similar "abnormal" protein in the sera of "cold exposed" rabbits, this does not preclude the possibility of the existance of such proteins. Through the use of different stains such as those for haptoglobins or another immunochemical technique, like the more definitive disc electrophoresis, similar abnormal proteins may be recognized.

The "loss" of the B lipoprotein fraction from the sera of a number of "cold exposed" animals as measured by starch gel electrophoresis cannot readily be explained, and maybedue mer ely to an alteration in the rate of migration. But this observation provides a fertile field for speculation. Masoro (1960) has reported that the cold acclimated rat has an increased capacity to oxidize long-chain fatty acids. A similar increased capacity on the part of the cold exposed rabbit would partially account for a lower level of slow migrating $B$ lipoprotein in this animal. Bertke (unpublished data) and others have reported a decrease in lipid content of the adrenals during stress. Such a decrease could presumably be reflected in a decreased level of circulating lipoprotein. A final speculation concerning a decreased B lipoprotein content of cold exposed rabbits concerns the role of heparin during periods of stress and/or shock. This compound, because of its strong polar properties, is capable of liberating the combined lipid from lipo- 
protein complexes. An increase in heparin would presumably cause a corresponding decrease in the level of circulating lipoprotein. An increase in heparin could presumably also play a role in the increased clotting time in cold exposed rabbits reported by Campbell and Sutherland (1951). It must be pointed out, however, that at the present time, we have no evidence for an increase in heparin in the circulating blood during periods of "cold stress".

While the consistent "tendency" of the sera of "cold exposed" rabbits to form sharper and clearer zones on starch gel provides a poor indication of any "differences" that might exist, this might be due to a greater degree of homogeneity of each of the different protein components measured by electrophoresis, which would result in a more nearly equal rate of migration. This homogeneity would then be reflected as less "trailing" in the stained starch gel pattern.

The value of immuno-electrophoretic analyses of sera from cold exposed and normal rabbits to the present investigation must await further application of this technique. The limitations when this technique is applied must be recognized. Further experimentation may also be necessary to determine optimal buffer $\mathrm{pH}$ values, ionic strength, and so forth, all of which are critical in this procedure. In spite of the apparent limitations of this procedure, however, it offers one of the most sensitive measures of qualitative antibody response that is presently available.

Future studies which are planned will include analysis of sera from rabbits exposed to more severe environmental conditions $\left(-15^{\circ} \mathrm{C}\right)$, and determinations of possible alterations in lipoproteins, haptoglobins, and other serum sub-fractions. Quantitative measurements of the $7 \mathrm{~S}$ and $19 \mathrm{~S}$ macroglobulins will be made by density gradient zone ultracentrifugation and chromatography on cellulose ion-exchange columns. It is anticipated that these and future investigations will provide information useful in determining the role of antibody in host-parasite interactions under conditions of hypothermia. 


\author{
SUMMARY
}

Immuno-chemical studies were conducted on sera from rabbits to investigate the qualitative and quantitative aspects of the immune response under conditions of "hypothermia". Rabbits have been subjected to lowered environmental temperature $\left(4^{\circ} \mathrm{C}\right)$, shaved of their pelage, and immunized with various protein antigens. Serum samples obtained from varying periods during each of the studies via cardiac puncture have been qualitatively assayed for antibody response by Ouchterlony gel diffusion, immuno-electrophoresis, starch gel electrophoresis, and paper electrophoresis. Quantitative analyses have included "ring" precipitin titrations, quantitative gel diffusion analysis, and micro-quantitative precipitin analysis. In all of the studies the response of the "cold exposed" animals have been compared with the "non-cold exposed" animals treated in an identical manner, except for maintenance at the lower environmental temperature.

\title{
LITERATURE CITED
}

1. Aladjem, F., R. W. Jaross, R. L. Paldino, and J. A. Lackner. 1959. The antigen-antibody reaction. III. Theor etical considerations concerning the formation, location, and curvature of the antigen-antibody precipitation zone in agar diffusion plates, and a method for the determination of diffusion coefficients of antigens and antibodies. J. Immunol. 83:221-231.

2. Baker, D. G., and E. A. Sellers. 1960. Unpublished. Inter mediary metabolism: Discussion. Symposium on cold acclimation. Federation Proc. 19: Supplement No. 5, p. 133.

3. Bertke, Eldridge. (Unpublished data) Arizona State University. 


\section{NORT HEY}

4. Campbell, Dan H. 1951. Immunochemical studies of arctic animals. A research report covering the period 1948-1950 for the Office of Naval Research.

5. Crowle, Alfred J. 1961. Immunodiffusion. Academic Press, New York.

6. Freund, Jules. 1947. Some aspects of active immunization. Ann. Rev. Microbiol. 1: 291.

7. Glenn, William G. 1959. Some considerations in agar column diffusion analyses. J. Immunol. 82: 120-124.

8. Jennings, Robert $\mathrm{K}_{\text {, }}$, and Morris A. Kaplan. 1962. Implications of qualitative comparative serology. Ann. Allergy 20: 15-28.

9. Jungeblut, C. W., M. Sanders, and R. R. Feiner. 1942. J. Exp. Med. 75: 611-629.

10. Lanni, F., M. L. Dillon, and J.W. Beard. 1950. Determinations of small quantities of nitrogen in serological precipitates and other biological materials. Proc. Soc. Exp. Biol. Med. 74: 4.

11. Moragues, V.9 and H. Pinkerton. 1944. J. Exp. Med. 79: 41-43.

12. Masoro, E. J. 1960. Alterations in hepatic lipid metabolism induced by acclimation to low environmental temperatures. Federation Proc. 19: Supplement 5, 115-119.

13. Moretti, J., G. Boussier, M. Hugou, and L. Hartmann. 1959. Bull. Soc. Chim. Biol. 41: 79-87.

14. Ouchterlony, O. 1949. Antigen-antibody reactions in gels. Acta Path. Microbiol. Scand. 26: 507-515.

15. Raffel, Sidney. 1961. Immunity. Appleton-Century Crafts, Inc. New York, 1953, p. 155. 
16. Sutherland, G. Bonar, and Dan H. Campbell. 1956. Cold adapted animals. I. Changes in blood clotting and electrophoretic properties of rabbit plasma. Proc. Soc. Exp. Biol. Med. 91: $64-67$.

17. Sutherland, G. Bonar, Ignatius L. Trapani, and Dan H. Campbell. 1958. Cold adapted animals. II. Changes in the circulating plasma proteins and formed elements of rabbit blood under various degrees of cold stress. J. App. Physiol. 12: 367-372.

18. Trapani, Ignatius L., and Dan H. Campbell. 1959. Passive antibody decay in rabbits under cold or altitude stress. J. App. Physiol. 14: 424-426.

19. Trapani, Ignatius L. 1960. Cold exposure and the immune response. Symposium on cold acclimation. Federation Proc. 19: Supplement No. 5, 109-114.

20. Uriel, J., and P. Grabar, 1956. Bull. Soc. Chim. Biol, 38: 1253-1269.

\section{DISCUSSION}

BLAIR: Is cold responsible for the changes that have been observed both with regard to the antibody turnover rates, and also with regard to the immuno-electrophoretic studies, or is cold simply a stimulus? In other words, could not the same situation be produced in the laboratory with stimuli other than temperature stimuli, but resulting in experimental preparations metabolically, at least, similar to that induced by cold? In other words, is not cold just a non-specific stimulus, or is cold really responsible for these changes?

TRAPANI: Are you asking about the effect of temperature at the cellular level? 
CAMPBELL: $\mathrm{He}$ is talking about hypothermia versus stress. You can have stress without hypothermia. You need to really lower the body temperature, which we haven't done. It has been done in the case of the hibernating squirrels. I think you would have to use an animal of this sort. Of course, this is an adaptation, and you have two problems. It seems to me one is a stress problem and the other is not.

BLAIR: That is right. What I am trying to clarify in my own mind is that the cold exposure is simply one of numerous stimuli that could be used to produce the same situation.

TRAPANI: I think this is true. What we are really dealing with in an animal that is cold exposed are the secondary factors which affect its response.

BLAIR: Could we call this the affect of cold on immune responses, really?

TRAPANI: If you put it in a cold box or out in the snow, a cold stress is imposed, and the index used for measuring the response is attributable to that stress, either directly or indirectly.

BLAIR: Suppose you produce a stress situation through another stimulus?

PREVITE: These responses to various types of stimuli, for example cold, heat, or sound, are not always the same.

MITCHELL: I wonder if we have a veterinarian around here who can tell us whether this is a stress or not. I want to know whether we are really and truly talking about a stress to these animals, or whether we are trying to talk about what would be a stress to a man if we did it to him?

REINHARD: Well, I think if the stress investigators conducted baseline experiments to determine the characteristics of the animal, that all animals would have similarities in their responses to stress. There is only one area in which man is 
different, and that is in the neurological and psychological response. When you talk about man, you have to introduce those factors, also.

BERRY: You are not excluding the psychological factor in animals, are you?

REINHARD: No, but they are quantitatively, and sometimes qualitatively different.

VIERECK: I completely agree with these comments by Dr. Reinhard. One type of baseline experiment would be to expose the animal to the cold temperature and measure food intake over a period of days. I think it is accepted that if the animals consume considerably more food, their metabolism has been higher and they have been under a sort of stress. Then this brings to mind another question. Some animals have been treated in this way, and they do indeed eat more food at certain low temperatures; thus they are eating more protein, and if an animal is consuming more protein for a period of time, will this, all by itself, affect the serum protein electrophoresis patterns regardless of cold exposure? In other words, could cold act via food intake? The protein turnover might be higher whether the stress were cold or whether it were something else.

SULKIN: This is precisely why I asked Dr. Campbell earlier whether he did the experiments with the arctic ground squirrels just at the time that they were going into hibernation. A bat just going into hibernation is not a stressed animal. However, if you are dealing with the same bat species in the cold room in the summertime, he is then in a state of hypothermia, and is in a stressed condition. While I don't intend to talk about electrophoretic changes, we have data showing that there is a difference in the analysis made in hypothermic bats and in hibernating bats, so it is important to emphasize the animal host and the season of the year.

TRAPANI: Is it a qualitative or quantitative difference? Do you pick up different components or the same components in different amounts? 


\section{NORTHEY}

SULKIN: I am not sure.

CAMPBELL: I suspect you might get a difference in the ratio or distribution in some proteins that might be there in minor amounts. Most of it is the ratio. Instead of being five per cent or ten per cent of the total proteins, it may go up to twelve or fifteen per cent. Now, under stress conditions, I cannot see that anything can happen within an hour or two or even within a few hours, other than changes in fluid balance perhaps; then you get changes in protein like the hibernating squirrel. It looks like its got a high protein concentration, which it has, but the total amount of protein may be actually the same as a normal animal. I don't know what the blood volume was because I didn't measure that.

PREVITE: I agree with what Dr. Sulkin stated a few minutes ago. There is a tremendous difference between hibernation and induced hypothermia. Dr. Lyman at Harvard has just emphasized this in a review on hibernation. In answer to Dr. Mitchell's question about stress, Dr. Cardy, ${ }^{2}$ of the University of Pennsylvania, noted that whether or not an animal is stressed depends upon the host and the conditions of the experiment.

MITCHELL: And the interpretation of the investigator in whether or not he is going to measure it by lowered temperature or the presence of this or the presence of that.

REINHARD: To reply to Dr. Mitchell, there is one more important factor. I wish more people would do comparative work using various species, because no one animal is exactly relevant to man, and they do differ in basic physiology, especially the gastroenterological portion of it.

MCCLAUGHRY: I think it might be well to keep in mind here the distinction between the physiological function of protein metabolism as it might be reflected by the antigen-antibody

1 Lyman, C. P. 1961. Circulation XXIV.

2 Hardy, J. D. 1961. Physlol. Rev. 


\section{IMMUNE RESPONSE IN COLD EXPOSURE}

response, and the function of the antibody as a protein component of the serum. These two things may not be exactly the same, and I think that there has been in the past an assumption that we are measuring these two things simultaneously in some of the studies reported. It occurred to me that it might be possible to distinguish these two separate physiological functions in some way.

NORT HEY: In terms of the comments about protein metabolism, one can't say an animal eats more and therefore produces more antibody. The antigenisticity of the substance under investigation makes a difference in probably a multitude of other factors.

CAMPBELL: That is why I was bringing up this last point; the persistence in antigens. 


\title{
INFLUENCE OF HYPOTHERMIA ON THE ACTION OF BACTERIAL TOXINS
}

\author{
G. Tunevall and T. Lindner \\ Central Bacteriology Laboratory \\ Box 177 \\ Stockholm 1, Sweden
}

\section{ABSTRACT}

In hypothermic mice with a body temperature of $22^{\circ} \mathrm{C}$ to $23^{\circ} \mathrm{C}$, given about one $\mathrm{DL}_{100}$ of tetanal toxin, the survival was significantly longer than in normothermic ones given the preparatory (Hibernal-Nembutal) treatment but not chilled (54 versus 29.5 hours at 48 hours of hypothermia). This result must be cautiously evaluated. Though hypothermia was not established until three hours after toxin injection, absorption from the subcutaneous site may be slower in hypothermic animals. Further, narcotic pretreatment drugs, though given also to the controls, may be more slowly eliminated by hypothermic mice, resulting in a milder and protracted course of the toxic manifestations. An attempt was done to find out if hypothermia prolonged the time during which toxin could be neutralized by antitoxin. Antitoxin after 15 minutes resulted in survival of all mice. At a toxin-antitoxin interval of four hours no animal was saved, but survival was prolonged and more so in hypothermic mice than was corresponded by the length of hypothermia ( 80 versus 43 hours at 4 hours of hypothermia). At an interval of 10 hours, survival was shorter in both groups, and the difference between hypothermic and normothermic mice equalled the duration of hypothermia ( 50 versus 39 hours at 10 hours of hypothermia). These observations must be corroborated by further experiments before they can be safely evaluated. The effects of staphylococcal toxin are less likely to be attenuated by the premedication pertaining to our procedure for inducing hypothermia. On the contrary, a synergism was observed between the narcotic drugs and this toxin, as amounts less than one conventional $\mathrm{DL}_{100}$ were sufficient to kill the mice. Also with this toxin, however, the survival was longer in hypothermic mice (3.5 versus 2 hours).

Induced hypothermia has been employed clinically in a variety of conditions, among others in intoxications. As seems often to be the case in connection with hypothermia, animal experimentation has been scarce and tended to lag behind the applications in human beings. 
The effect of tetanus toxin on mice subjected to low environmental temperature was studied by Ipsen (1951). The survival after large toxin doses was prolonged in chilled animals, whereas sublethal doses caused more deaths in chilled mice than in those kept at normal room temperature. Increased susceptibility to endotoxins from Gram-negative bacteria of mice held at $5^{\circ} \mathrm{C}$ and $15^{\circ} \mathrm{C}$, when compared to animals at room temperature was found by Previte and Berry (in press). In hypothermia induced so as to avoid stress reactions, no effect on the hematologic or histologic manifestations of staphylococcal exotoxin in rabbits was found by Cole (1960).

\section{EXPERIMENTAL}

\section{Material and Methods}

Albino mice weighing 20 to $40 \mathrm{gm}$ were numbered serially. The allotment of animals to different experimental groups was done by a random method according to the tables of Fisher and Yates (1953).

For inducing hypothermia the following procedure was used: A subcutaneous injection of $32 \mathrm{mcg} / \mathrm{g}$ body weight of Chlorpromazine$\mathrm{HCl}$ is followed after $30 \mathrm{~min}$. by an intraperitoneal injection of half this amount of ethyl-(1-methyl-butyl)-malonyl-carbamide-Na. The mice are then, in their narcotized state, fixed onto suitably formed lead plates with adhesive tape and immersed in a supine position into a $21^{\circ} \mathrm{C}$ water bath with only the head and part of the thorax above the water. The rectal temperature will be stabilized within one hour between $21.5^{\circ} \mathrm{C}$ and $23.5^{\circ} \mathrm{C}$, and the temperature in lower esophagus will be stabilized about $0.5^{\circ} \mathrm{C}$ higher. Oxygen and carbogen are administrated continuously to the chamber formed by the water bath and its fairly tightly closed cover.

Rewarming starts with slowly raising water temperature to $33^{\circ} \mathrm{C}$ over a 4 to 5 hour period. When they begin to show activity, the mice are freed from the lead plates, dried, transferred to their 
original containers, and placed into an air incubator generally at $35^{\circ} \mathrm{C}$ for the first 2 hours, then at $31^{\circ} \mathrm{C}$ for 24 hours. Humidity is kept around 50 per cent, and oxygen administration is continued. After this period, the mice can be kept under normal conditions.

Nor mothermic controls are given the same premedication, whereby rectal temperature decreases by $2^{\circ} \mathrm{C}$ to $5^{\circ} \mathrm{C}$, but are immediately transferred to the air incubator, and from that point treated as above.

Tetanus and staphylococcal toxins and antitoxins were obtained from the Swedish State Bacteriological Laboratory. In preliminary experiments on normal mice of our breed, their $\mathrm{MLD}_{100}$ neutralizing doses were determined. The routes of administration of these products will be given for each experiment.

\section{RESULTS}

In a first experiment presented in Fig. 1, twenty mice were given one $\mathrm{MLD}_{100}$ of tetanus toxin subcutaneously. Two hours later hypother mia was induced in ten mice which were then kept in this state for about 48 hours. The other ten mice received pretreatment only. Tetanic manifestations were only slight in the hypothermic animals in comparison with those of the controls, but at rewarming, after 48 hours, paroxysms grew more frequent and intense. One nor mothermic mouse was lost because it was severely bitten, and two hypothermic ones were lost from drowning. Therefore, recording of survival times could be done only in nine normothermic mice and in eight hypothermic mice, as reported in Fig. 1.

The average survival within the hypothermic group was significantly longer than among normothermic controls, as is visible from Fig. 2. In addition, it can be mentioned that two mice only died during the period of hypothermia, two during the first stage of rewarming in the water bath, one during the stay in air incubator at $35^{\circ} \mathrm{C}$, and the remaining three 5 or 6 hours after the change of 


\section{TUNEVALL AND LINDNER}

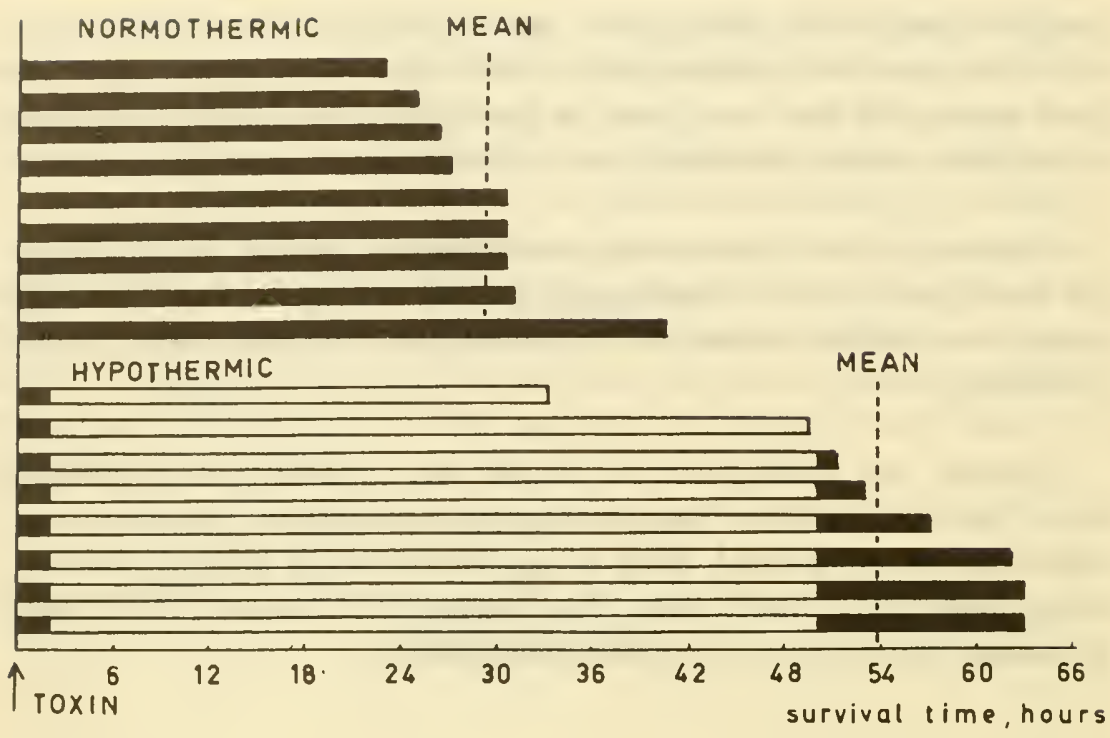

Figure 1. Survival times in mice given one $M L D_{100}$ of tetams toxin. White parts of columns mark period of hypothermia. Number of mice: Normothermic 9 , hypothermic 8 .

\begin{tabular}{lccccc} 
Group & $\begin{array}{c}\text { Number } \\
\text { of } \\
\text { mice }\end{array}$ & $\begin{array}{c}\text { Survival } \\
\text { in hours }\end{array}$ & Diff. & $t$ & $P$ \\
\hline Normothermic & 9 & $29.5 \pm 1.7$ & & \\
Hypothermic & 8 & $54.0 \pm 3.5$ & & $6.2<0.001$
\end{tabular}

$$
\text { Formulae used: } \begin{aligned}
s & = \pm \sqrt{\frac{\sum(x-\bar{x})^{2}+\sum(y-\bar{y})^{2}}{n_{x}+n_{y}-2}}, \text { and } \\
t & =\frac{D}{s \sqrt{\frac{x y}{x+y}}}
\end{aligned}
$$

Figure 2. Survival times in hours $(M \neq e(M))$ of mice after subcutaneous injection of equal doses of tetams toxin. Start of hypothermia 2 hours, rewarming 48 hours after the injection. 
temperature to $31^{\circ} \mathrm{C}$.

The above results could at least partially be due to a slower fixation of the toxin to susceptible cells in hypothermic animals. Therefore, new experiments were set up in order to find out if hypothermia prolonged the time during which the toxin remained free to be neutralized by antitoxin.

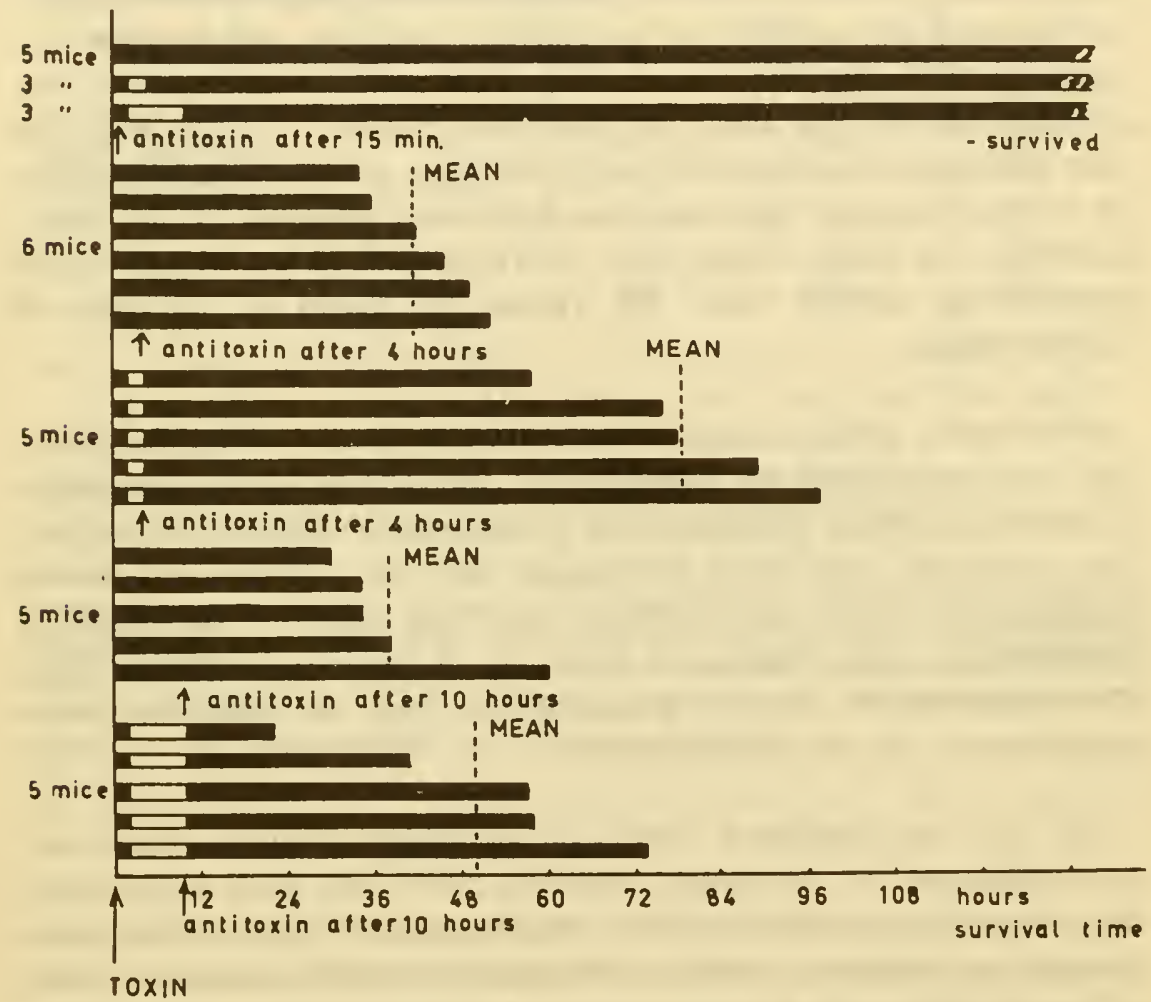

Figure 3. Survival times in mice given one $M L D_{100}$ of tetamus toxin and, after intervals of 15 minutes, 4 hours and 10 hours, one neutralizing dose of antitoxin. White parts of columns mark period of hypothermia, induced two hours after the toxin injection and maintained for two or elght hours.

The results of one experiment are reported in Fig. 3. In all, 35 mice were given one $\mathrm{MLD}_{100}$ subcutaneously. They were allotted to three groups containing 11,12 , and 12 animals respectively. In the first group, one neutralizing dose of antitoxin was given, also subcutaneously, 15 minutes after the toxin injection. About $1-1 / 2$ 
hours later, hypothermia was induced in six mice and maintained for 2 hours in three animals and for 8 hours in the other three. Five mice were kept normothermic. In this group all eleven mice survived, but it is not included in the table.

In the second group six mice were made hypothermic $1-1 / 2$ to 2 hours after the toxin injection, and the other six kept normothermic. All animals got antitoxin 4 hours after the toxin, and then the rewarming of the hypothermic animals was immediately begun. In this group no animal was saved, as seen from Figure 3 , but the survival was prolonged in comparison with the first experiment; especially so in hypothermic animals. The difference effected by the hypothermia was much larger than corresponded to the length of the hypothermic period itself ( 80 versus 43 hours at two hours of hypothermia).

The third group received antitoxin 10 hours after the toxin, and the rewarming of hypothermic mice was also begun after 10 hours. In other respects this group was treated as the second. The survival was still prolonged, but the difference between hypothermic mice and controls was only equal to the length of hypothermia (50 versus 39 hours at 8 hours of hypothermia). This experiment is also presented in Fig. 4, which states the significance of the observations.

As will be discussed later on, the effect of tetanus toxin may be influenced by irrelevant factors. The next part of the study was therefore performed with staphylococcal toxin which was, as well as antitoxin, always administered intravenously in order to avoid differences in absorption from local sites of injection. Preliminary experiments had shown that a dose of staphylococcal toxin large enough to kill all mice in the groups resulted in very short survival, generally ranging between 1 and 4 hours. It was further found that about $0.8 \mathrm{MLD}_{100}$ was enough to kill mice which had received the pretreatment whether they were made hypothermic or not.

In the first series of experiments, the influence of hypothermia on the survival times after lethal doses of the toxin was investigated. Groups of normothermic mice which received the 


\begin{tabular}{|c|c|c|c|c|}
\hline $\begin{array}{l}\text { Toxin-antitoxin } \\
\text { interval, hours }\end{array}$ & \multicolumn{2}{|c|}{4} & \multicolumn{2}{|c|}{10} \\
\hline State & $\begin{array}{l}\text { Normo- } \\
\text { thermic }\end{array}$ & $\begin{array}{l}\text { Hypo- } \\
\text { thermic }\end{array}$ & $\begin{array}{l}\text { Normo- } \\
\text { thermic }\end{array}$ & $\begin{array}{l}\text { Hypo- } \\
\text { thermic }\end{array}$ \\
\hline $\begin{array}{l}\text { Number of } \\
\text { mice }\end{array}$ & 6 & 5 & 5 & 5 \\
\hline $\begin{array}{l}\text { Survival time } \\
\text { in hours }\end{array}$ & $\begin{array}{l}52 \\
45 \\
42 \\
34 \\
49 \\
36\end{array}$ & $\begin{array}{l}98 \\
77 \\
58 \\
76 \\
89\end{array}$ & $\begin{array}{l}60 \\
34 \\
38 \\
31 \\
34\end{array}$ & $\begin{array}{l}58 \\
57 \\
41 \\
74 \\
22\end{array}$ \\
\hline$M \pm e(M)$ & $43 \pm 2.9$ & $80 \pm 6.8$ & $39 \pm 5.3$ & $50 \pm 8.8$ \\
\hline
\end{tabular}

$$
\begin{aligned}
& \text { Comparison 1.-2.: } D=37 . t=4.8 \quad P<0.001 \\
& \text { 2.-4.: } D=30 . \quad t=2.7 \quad 0.05>P>0.02
\end{aligned}
$$

Figure 4. Survival times in hours of mice given one neutralizing dose of antitoxin serum 4 versus 10 hours after the tetanus toxin injection. Start of hypothermia 1-2 hours after the toxin injection, warming up immediately after the injection of antitoxin. ( 5 normothermic mice, 3 hypothermic for 3 hours, and 3 hypothermic for 9 hours, all receiving antitoxin after $15 \mathrm{~min}$., survived).

pretreatment only were run. The toxin injection was always made after the start of hypothermia. The experiments differed slightly as to the period of hypothermia preceding the toxin injection and the dose of toxin, but hypothermia was always maintained to the end of the experiments. The results are given in Fig. 5.

Thus, in all groups, the average survival was longer in hypothermic mice. The differences within the groups were significant, and if all the material is taken together, they were even more significant. It was next attempted to study the influence of hypothermia on the time during which staphylococcal toxin could be neutralized by antitoxin to a degree sufficient to save the mice or at least prolong their survival in a manner similar to 


\begin{tabular}{|c|c|c|c|c|c|c|c|c|}
\hline \multirow{2}{*}{$\frac{\text { Group }}{\text { State }}$} & \multicolumn{2}{|c|}{1.} & \multicolumn{2}{|c|}{2.} & \multicolumn{2}{|c|}{3.} & \multicolumn{2}{|c|}{4.} \\
\hline & N & H & $\mathbf{N}$ & $H$ & $\mathrm{~N}$ & H & $\mathrm{N}$ & H \\
\hline $\begin{array}{l}\text { Survival, } \\
\text { minutes }\end{array}$ & $\begin{array}{r}105 \\
60 \\
100 \\
30 \\
100 \\
100 \\
75 \\
90 \\
80 \\
80\end{array}$ & $\begin{array}{l}225 \\
160 \\
250 \\
150 \\
150 \\
195 \\
240 \\
230 \\
200 \\
230\end{array}$ & $\begin{array}{l}130 \\
160 \\
120\end{array}$ & $\begin{array}{l}180 \\
150 \\
215 \\
210 \\
210 \\
220 \\
230 \\
265 \\
230\end{array}$ & $\begin{array}{r}80 \\
190 \\
100 \\
150 \\
120\end{array}$ & $\begin{array}{l}200 \\
190 \\
240 \\
230 \\
180\end{array}$ & $\begin{array}{r}110 \\
110 \\
140 \\
50 \\
70\end{array}$ & $\begin{array}{l}345 \\
370 \\
100 \\
195 \\
380\end{array}$ \\
\hline $\begin{array}{l}M \\
e(M)\end{array}$ & $\begin{array}{l}82 \\
+\quad 7.3\end{array}$ & $\begin{array}{c}203 \\
+12.0\end{array}$ & $\begin{array}{l}137 \\
\pm 12.0\end{array}$ & $\begin{array}{c}212 \\
\pm 10.8\end{array}$ & $\begin{array}{c}128 \\
\pm 19.3\end{array}$ & $\begin{array}{c}208 \\
\pm 11.6\end{array}$ & $\begin{array}{l}96 \\
\pm 16.0\end{array}$ & $\begin{array}{l}278 \\
\pm 55.7\end{array}$ \\
\hline Diff. & \multicolumn{2}{|c|}{121} & \multicolumn{2}{|c|}{75} & \multicolumn{2}{|c|}{80} & \multicolumn{2}{|c|}{182} \\
\hline $\begin{array}{l}\text { t-value } \\
\text { Degrees } \\
\text { of freedom }\end{array}$ & \multicolumn{2}{|c|}{8.58} & \multicolumn{2}{|c|}{3.64} & \multicolumn{2}{|c|}{3.55} & \multicolumn{2}{|c|}{3.14} \\
\hline$P$ & \multicolumn{2}{|c|}{$<0.001$} & \multicolumn{2}{|c|}{$0.01-0.001$} & \multicolumn{2}{|c|}{$0.01-0.001$} & \multicolumn{2}{|c|}{$0.02-0.01$} \\
\hline
\end{tabular}

Total N: $102 \pm 7.6$ Diff. 118. $t=8.09$. dF 50. $P<0.001$ Total H: $220 \pm 11.5$

Figure 5. Survival times in normothermic versus hypothermic mice given one MLDjoo of staphylococal toxin. Hypothermia induced about 5 hours before the toxin injection. $(\mathrm{N}=$ normothermic. $\mathrm{H}=$ hypothermic).

the work on tetanus toxin. In order to establish suitable experimental conditions, a number of neutralization tests were first set up in normothermic mice given only the pretreatment. The results are reported in Fig. 6 and Fig. 7.

As the number of mice was small and as the results emanate from several experiments, no statistical treatment has been done, but generally, there was a good correlation between the length of the toxin-antitoxin interval and the survival times. Essentially, the experiments differed in one respect only; in one group, the antitoxin dose was increased from one to four neutralizing units, and the results of this experiment are reported in Fig. 6 and Fig. 7. 


\begin{tabular}{|c|c|c|c|c|c|c|c|c|c|}
\hline $\begin{array}{l}\text { Survival } \\
\text { minutes }\end{array}$ & 60 & $\begin{array}{r}61- \\
75\end{array}$ & $\begin{array}{r}76- \\
90\end{array}$ & $\begin{array}{l}91- \\
120\end{array}$ & $\begin{array}{l}121- \\
150\end{array}$ & $\begin{array}{l}151- \\
180\end{array}$ & $\begin{array}{l}181- \\
240\end{array}$ & $\begin{array}{l}241- \\
480\end{array}$ & 00 \\
\hline $\begin{array}{l}\text { Interval } \\
\text { minutes }\end{array}$ & & & & & & & & & \\
\hline 1 & 1 & . & . & . & & & & & $5 / 7$ \\
\hline 2 & & & & 4 & 1 & & & 2 & $/ 5$ \\
\hline $3-5$ & 1 & & & 1 & 1 & 2 & 1 & 1 & 11 \\
\hline $6-15$ & 2 & 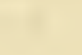 & 1 & 3 & 1 & 1 & 1 & & \\
\hline $16-25$ & 1 & 2 & & & 11 & $1 / 3$ & & & \\
\hline $26-45$ & & & & & 11 & & & & \\
\hline $46-60$ & & & $/ 1$ & & & & & & \\
\hline
\end{tabular}

Figure 6. Survival times of 51 pretreated but normothermic mice after intravenous injection of one lethal dose of ataphylococcal toxin, followed by one or (bottom right in the columns) four neutralizing units of antitoxin after different intervals.

Common to all groups was the observation that increasing toxin-antitoxin interval diminished the ability of antitoxin to prolong the survival. The larger dose of antitoxin gave more absolute survivals and at longer toxin-antitoxin intervals increased survival times.

As to the influence of hypothermia on the time relationships described in the Figures 6 and 7 , the work in this area is in its beginning stages. Only one of the experiments has contained five animals made hypothermic about five hours prior to the injection of toxin. They all represent a toxin-antitoxin interval of two minutes. The average survival time of these mice was 284 minutes, and the result is marked as a single point in the figure. This is situated well above the curve for normothermic mice given the same antitoxin amount, one neutralizing dose, but there is no statistical difference between this average and that of the normothermic mice in the same experiment $(t=1.7$; dF $8 ; P>0.1)$. 
Survival time, minutes

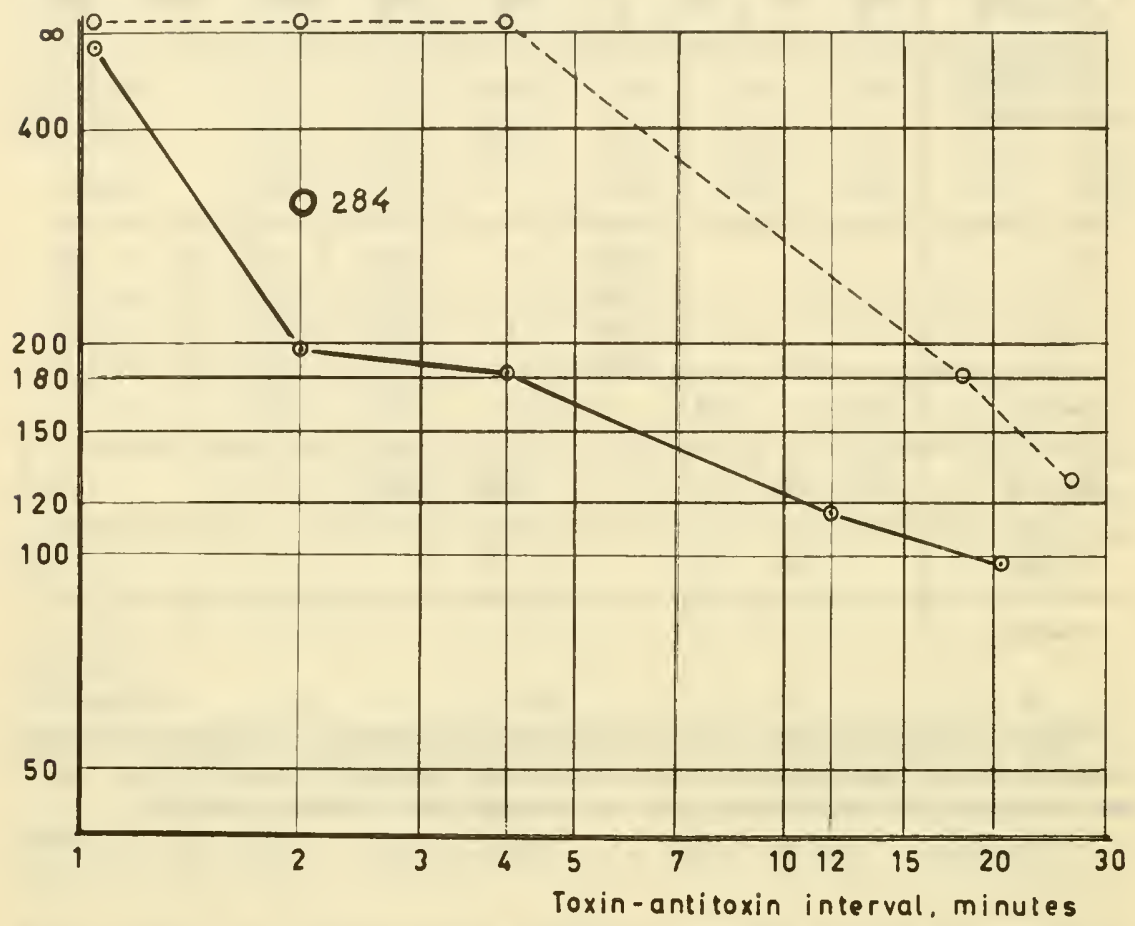

Figure 7. Average survival times of groups of normothermlc mice given one $M L D_{100}$ of staphylococcal toxin and, after different intervals, one or four (broken line) neutralizing doses of homologous antitoxin. Same average for a group of five hypothermic mice is marked as a single point.

\section{DISCUSSION}

It should first be pointed out that our experiments involve a procedure for attaining hypothermia by the elimination of the normal thermoregulation; thus, hypothermia is reached without stress reactions. 
The first experiment indicated a significantly prolonged survival time and milder tetanic manifestations in hypothermic mice. These mice, however, got more pronounced tetanus and died at or very soon after rewarming. To this result, which may mean simply that a postponement of the toxic effect has come to an end, may be contributed the trauma induced by the rewarming process itself. The possibility also remains that warming up effects a compensatory overnormal metabolism, thus giving the toxin an especially good access to susceptible cells.

If the protective effect of hypothermia is due to a retarded fixation of the toxin to its receptor cells, hypothermia should prolong the period during which the toxin may be neutralized by antitoxin before its entry into these cells. Too few experiments have been made to allow a safe verification of this assumption, but it is interesting to note that with a toxin-antitoxininterval of four hours, a two hour period of hypothermia increased the average survival to not less than 37 hours. Further experiments are planned to investigate whether this increase may be converted to a lasting survival if an adequate toxin-antitoxin interval is chosen.

The evaluation of these results with tetanus toxin must be made with great caution. The injection of toxin was made subcutaneously and though hypothermia did not start until about 2 hours after the injection, part of the toxin may have been more slowly absorbed in hypothermic animals. Furthermore, narcotics, as a rule, have an attenuating effect on tetanic manifestations. There are good reasons to believe that the drugs given as pretreatment are more slowly eliminated in hypothermic animals, and this may account for at least part of the protective effect of hypothermia. Therefore, staphylococcal toxin was chosen for the subsequent tests. In this case the situation is apparently reversed, in that the effect of this toxin seems to be enhanced by the narcotics used for pretreatment.

Hypothermia was also found to prolong the survival time after the injection of staphylococcal toxin. On the basis of the same considerations as for tetanus toxin, a series of neutralization tests have been begun which have already indicated a fairly good correlation between the time allowed to pass between the injections of toxin and antitoxin, and the ability of antitoxin to prolong the survival time in 
nor mothermic mice. The ability of hypother mia to alter this relation is not yet verified, but according to a first experiment, it seems probable that it will be.

\section{SUMMARY}

In hypothermic mice with a body temperature of $22^{\circ} \mathrm{C}$ to $23^{\circ} \mathrm{C}$ given lethal doses of tetanus toxin, the survival time was significantly longer than in nor mothermic controls given a preparatory (Hibernal-Nembutal) treatment but not chilled. The tetanus was also less pronounced in hypothermia, but increased at the rewarming procedure. During or soon after rewarming, the animals died.

The ability of antitoxin to prolong the survival in normothermic mice varied with the interval between the injection of toxin and antitoxin administration. When hypothermia was maintained during part of this interval, the survival was significantly more prolonged, and much more than corresponded to the length of the hypothermic period.

For several reasons, these results must be cautiously evaluated, but they suggest that the fixation of toxin to susceptible cells is retarded in hypothermia.

In another series of experiments with staphylococcal toxin, similar results were obtained. Hypothermia prolonged survival and the neutralizing effect of antitoxin diminished when the toxin-antitoxin interval increased. That hypothermia may prolong the period during which neutralization is possible is not yet known, but a first experiment of a series to be continued in the future points in this direction. 


\section{HYPOTHERMIA AND BACTERIAL TOXINS}

\section{LITERATURE CITED}

1. Cole, W. R. 1960. Studies in hypothermia and staphylococcus toxin shock. Dissertation Abstr. 20: 4373.

2. Fisher, Ronald A., and Frank Yates. 1953. Statistical tables for biological, agricultural, and medical research. Hafner Publ. Co., Inc.

3. Ipsen, J. 1951. The effect of environmental temperature on the reaction of mice to tetanus toxin. J. Immunol. 66:687.

4. Lindner, T., and G. Tunevall. 1958. Hypothermia and infection. I. Influence of hypothermia on antibody formation in mice in the secondary response to typhoid-H-antigen. Scand. J. Clin. Lab. Invest. 10: 142.

5. Previte, J. J., and L. J. Berry. In press. The effect of environmental temperature on the host-parasite relationship in mice. J. Infect. Dis.

\section{DISCUSSION}

SULKIN: I think it might be of interest to recall some experiments that were reported in the early twenties by Bronfenbrenner and Weiss ${ }^{1}$ in which it was shown that ether anesthesia, alone and in combination with specific antitoxin, decreased mortality in experimental botulism in mice. On the basis of these early studies, I became interested in the effect of anesthesia on experimental viral infections ${ }^{2}$ and found that many animals 
would survive infection with Western equine virus if they were kept under anesthesia for prolonged periods of time, and furthermore, by using hyper-immune serum additional animals would survive. 3

CAMPBELL: What is your prolonged period of time?

SULKIN: Three 4-hour periods of diethyl ether anesthesia were used. A similar underlying mechanism may be involved, since during anesthesia the temperature falls as a result of diminished muscular activity and increased heat loss.

BLAIR: I think this is a very interesting piece of work, and while the experimental model, Dr. Tunevall, is quite different than the one which I will discuss the day after tomorrow, I believe that the philosophies are probably going to be quite similar. There are two probable foci of activity, one which you have emphasized; that dealing with the toxin-antitoxin activity, that is, the activity of the organism depending on the organism itself. And of course, the other site of action is the host itself; that is, the overall physiological integrity of the host as a result of the induced infection. I think that the point that you made is that hypothermia seemed to postpone the activities. I have found this to be very much the same situation, using gram negative coliform bacillus in my own studies. I hate to give away all my thunder, but I think it is apropos since your work does dovetail so well with it. It is simply that the hypothermia doesn't really alter these things to a tremendous extent permanently. It is particularly striking that upon rewarming there was a very high death rate. This re-emphasizes the matter somewhat and the picture of death and prevalent death is identical upon rewarming.

BLAIR: The point is, that we have to consider very carefully the level of hypothermia that we are talking about, and using in the experimental model, particularly with relation to overall physiological changes as presumably benefits the un- 
fortunate situation which it creates, and then, of course, the level of hypothermia which may have a more direct effect upon the organisms in question.

PREVITE: I am curious, Dr. Tunevall, as to why you didn't make your normothermic mice swim for two hours in a water bath at thirty-seven degrees just to make the two groups comparable. You tied the mice down and made them swim in cold water, but not warm water.

TUNEVALL: I don't know how to get them to stay in the water bath.

MIRAGLIA: If you place the animals in the containers that have very smooth vertical sides, there is no difficulty in keeping the animal swimming continuously for over an hour.

MONCRIEF: At Denver, they tried that and they just stiffened their tails up and stood on them, or else balanced their chins and their tails on both sides of the container.

BLAIR: Apparently I should harbor resentment, Dr. Tunevall, in your initial observation that the cart came before the horse with regard to using hypothermia. I have been "guilty". I refuse to take the stand or stand court trial on this, but hypothermia probably has been exercised rather liberally with patients before there has been, shall we say, adequate research or experimental investigation. I do wish to state, though, that there has been a tremendous amount of research in hypothermia for many years before this modern, so-called era of clinical application. But it is true, however, that there are many facets that we know very little about, particularly with regard to infections, on the hazards of hypothermia. Part of this has been demonstrated by virtue of the fact that there has been a good deal of difference as reported on results and literature on experimentally induced infections using pheumococcus, for example. The animals were cooled -- I believe these were mice -- to very profound levels of $20^{\circ} \mathrm{C}$. While there was one report of some improvement of survival, actually there were other reports which indicated a higher death rate. I think that Dr. Eisman 
did this. I was in Colorado last March and talked with one of his young gentlemen. They have since repeated this work using more moderate levels of cooling -- $30^{\circ} \mathrm{C}--$ and the opposite result was obtained. There was a much more significant rate of survival at the more moderate level of cooling, and this obviously related to the host problem that I mentioned.

TUNEVALL: My characterization of the situation relates to the early 1950 's when hypothermia was already being used therapeutically in several clinical conditions. I don't think they knew very much what they were doing then.

BLAIR: I discussed it a few moments ago. They used artificial hibernation, and I hate those words.

CAMPBELL: Do you think new immunomechanisms, antibodies, play any part in it?

TUNEVALL: In this connection, no, I don't think so.

CAMPBELL: But there aren't any so-called natural antibodies on the antigens that you were testing?

BERRY: In that connection, at the meetings in Montreal it was said by one of the speakers on a symposium ${ }^{4}$ that all animals have a very high immunity, not a natural immunity. It is acquired through contact with staphylococci and this is the reason why any immunization against staphylococci is so unsuccessful. They are already maximumally immunized. This is a concept that never occurred to me, but maybe it has some validity, at least in regard to the staphylococcin antibodies not normally present as a result of the contact.

TUNEVALL: I think that the only way to bring active antibody formation into this picture would be to arrange for a secondary response. 
CAMPBELL: I was thinking of the situation in which the antibodies are already there and they are less operative. I do not know the mechanism on neutralization, but you do have stress conditions in which you can reduce shock, particularly in mice, by injecting cortico steroid. If you inject it ten or fifteen minutes before you inject antigen, you can reduce the hypersensitivity of the reaction.

BERRY: Dr. Previte did some experiments with staphylococci.

PREVITE: Yes, that was part of a study on cold exposure. However, since the experiments were of short duration, and since rectal temperatures of staphylococcus toxin injected animals were not measured, and hypothermia was not induced, the results are probably not applicable to Dr. Tunevall's findings.

BERRY: No, they are not directly so, but there was no effect of cold exposure under your conditions?

PREVITE: No, because the number of animals used was not large enough. However, the results did indicate that a significant effect would have been demonstrable with a larger number of mice.

MITCHELL: Saint Patrick did such a good job over in Ireland, but would the same mechanisms that you are talking about relative to hypothermia, and with your so-called antitoxin, work also for venoms of snakes?

BERRY: You are asking Dr. Tunevall?

MITCHELL: Yes.

ANDREWES: He didn't know about Saint Patrick.

MITCHELL: Saint Patrick did a good job of cleaning up Ireland of snakes for the poor. Actually, what I am talking about is whether or not the mechanism you have described, say, for staph-toxin, and for one of your other toxins, works equally well for venoms of what we call our rattle snake, or in our 
country, the coral snake, or perhaps the cobra; now, whether or not these could be employed, because we do have situations in which this occurs, becomes a very important facet of a military operation.

TUNEVALL: I can only guess in that connection, and guesses are not sure.

BERRY: You have not used the intravenous route of administration of toxins and antitoxins?

TUNEVALL: Yes, I have injected by the intravenous route.

PREVITE: There have been some reports in which rabbits rendered hypothermic and infected with staphylococcus manifested prolonged survival compared to homeothermic infected controls. Staphylococci were injected into the bones of the rabbit. 5

BLAIR: I think an important matter here is that there have been various types of experimental models also in administration as well as type of organism used, but the important thing to me is the fact that while survival was prolonged, all of the animals succumbed. There have been no experiments with permanent survival, and that is a very important matter because, as I will discuss again in detail the day after tomorrow, I think that in the viewpoints concerning the role of "therapeutic" hypothermia, we are going to need some very definite clarification. Obviously, the situation which does not produce full, long-term survivals can hardly be considered efficacious.

PREVITE: Yes, but it might be used as an adjunct with something else.

WALKER: Or it may provide you with time to do something like administer antitoxin. 


\section{BLAIR: Yes.}

CAMPBELL: Concerning the basic immune mechanism, this occurred to me. I wonder if anyone has studied the effect of hypothermia on the threshhold reaction to histamine acetycholine, or so-called slow reacting substance. That would be a fairly interesting problem.

NORTHEY: Well, I'd just like to add to that a little. We have done some preliminary studies in which we sensitized cold exposed and control Guinea pigs to egg albumin and later on moved the uterine horn and/or a strip of smooth muscle from the intestine. With both the egg albumin antigen and histamine we stimulated these tissues in the cold exposed and non-cold exposed Guinea pigs. The responses were measured on a physiograph. In these preliminary experiments which were made with ten or twelve animals per study group, we were able to see no significant differences in the responses of the cold exposed animals from those in the controls.

BLAIR: I can't remember the details, but the Schwartzman phenomenon was studied. I don't know if this falls strictly into the category that you mentioned, but the cutaneous manifestations are delayed, and if they do appear, they are considerably less.

TRAPANI: Is that because skin temperature is different from core temperature?

BLAIR: No, this is a stabilized state and during stabilized hypothermia, the gradient between the skin and the core is very much the same in the hypothermia as it is without the hypothermia, so the skin temperature, of course, is lower, and this might be part of that. The blood flow to the skin has been measured in hypothermia and during this stabilized state. It is reduced, but not considerably. It is markedly reduced, of course, during the period of cooling, but in the so-called steady state, the blood flow to the skin is fairly substantial.

TRAPANI: But you can still have an actual temperature effect, 
TUNEVALL AND LINDNER

per se, on the cellular mechanism?

BLAIR: Oh, yes. Of course, the skin and temperature, per se, is lower; however, it gradually begins to rise in the room temperature environment. 



